\title{
Simple Molecules, Highly Efficient Amination
}

\author{
Shunsuke Chiba and Koichi Narasaka
}

\section{1}

\section{Introduction}

In the last two decades, explosive progress has been made in synthetic methods for production of amino compounds, due to their rapidly increasing applications in pharmaceutical and material sciences. Development of amination reagents for the construction of new carbon-nitrogen bonds is one of the most important and basic processes for the synthesis of amino molecules, and this chapter introduces simple and useful amination reagents classified by reaction type, such as electrophilic amination reagents, including transition metal-nitrene and nitrido complexes, radical-mediated amination reagents, and nucleophilic amination (Gabriel-type) reagents.

\section{2}

\section{Hydroxylamine Derivatives}

Hydroxylamine derivatives are one of the most versatile and simple amination reagents, leading the variety of nitrogen-containing compounds. This section mainly focuses on recent advances in electrophilic amination of carbon nucleophiles with various hydroxylamine derivatives.

\subsection{1}

\section{O-Sulfonylhydroxylamine}

Tamura has reported the synthesis of O-mesitylsulfonylhydroxylamine (MSH; 1; Figure 1.1) and related compounds and has examined their reactions with various nucleophiles in detail [1]. With regard to the formation of $\mathrm{C}-\mathrm{N}$ bonds by the use of MSH, however, the applicable carbanions were quite limited - to stabilized enolates only - and the product yields of the resulting amines were quite low.

The electrophilic amination of organolithium compounds with the methyllithium-methoxyamine system, long recognized as a potentially useful 


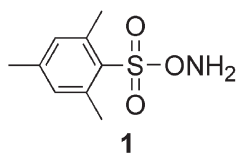

Figure 1.1 Tamura reagent (MSH) 1.

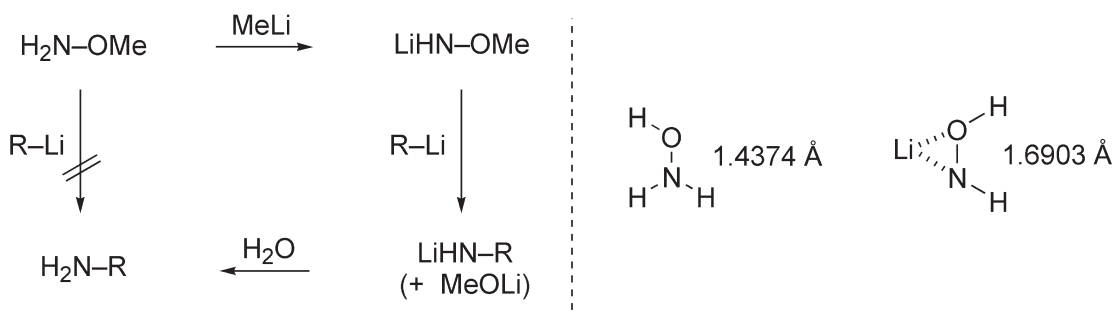

Scheme 1.1 Electrophilic amination with the methyllithium-methoxyamine system.

amination method (Scheme 1.1), was discovered by Sheverdina and Kocheskov in 1938 [2]. Overall the process is a formal displacement of the methoxy group of the lithium methoxyamide intermediate with the carbanion. Model calculations performed to provide insight into the electrophilic properties of LiHN-OMe showed that the $\mathrm{N}-\mathrm{O}$ bond in $\mathrm{LiHN}-\mathrm{OMe}$ is bridged by $\mathrm{Li}$ and is longer than the related bond in $\mathrm{H}_{2} \mathrm{~N}-\mathrm{OMe}$ [3]. This would suggest a particular significance of the nitrenoid-like structure for the facile cleavage of the $\mathrm{N}-\mathrm{O}$ bond.

These concepts have been translated into the design of some $\mathrm{O}$ sulfonylhydroxylamines such as tert-butyl- $N$-tosyloxycarbamate (2) [4] and allyl- $N$ tosyloxycarbamate (3) [5], which can be easily prepared and are stable enough to handle. Actually, Boche et al. reported the crystal structure of lithium tert-butyl- $N$ mesityloxycarbamate and revealed that the $\mathrm{N}-\mathrm{O}$ bond is longer than that in the neutral compound, tert-butyl- $\mathrm{N}$-mesityloxycarbamate, which supports the calculations mentioned above [6].

Lithium tert-butyl- $N$-tosyloxycarbamate (4) and lithium allyl- $N$ tosyloxycarbamate (5), generated by treatment of 2 and 3 with butyllithium in THF at $-78^{\circ} \mathrm{C}$, are useful for the preparation of $N$-Boc and $N$-Alloc amines. A variety of $\mathrm{N}$-protected alkyl, aryl, and heteroaryl primary amines can be synthesized by treatment with the corresponding organolithium and -copper reagents (Schemes 1.2-1.5).

The amination of $\alpha$-cuproamides and $\alpha$-cuprophosphonates also proceeds effectively through the use of lithium tert-butyl- $N$-tosyloxycarbamate (4) and allyl- $N$ tosyloxycarbamate (5) to give $\alpha$-amino acid derivatives. Asymmetric synthesis of $\alpha$-amino acid derivatives is achieved by the amination of chiral amide cuprates with lithium tert-butyl- $N$-tosyloxycarbamate (4; Scheme 1.6) [7].

These methods can be applied to the amination of organoboranes [8]. Primary alkyl boranes rapidly react with lithium tert-butyl- $N$-tosyloxycarbamate (4) in a 1:1 molar ratio to give $N$-Boc-protected primary amines in good yield (Scheme 1.7). 


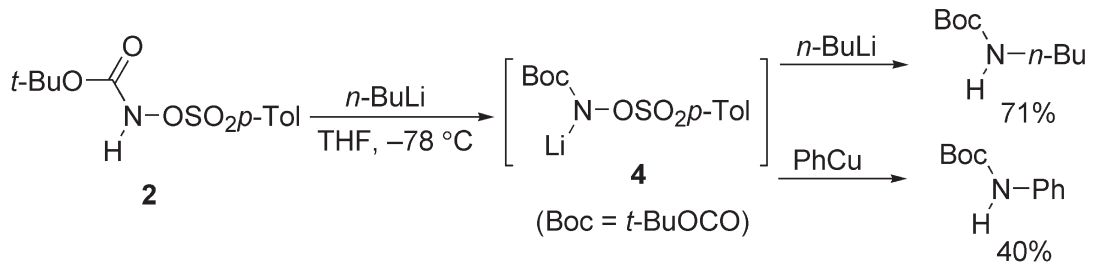

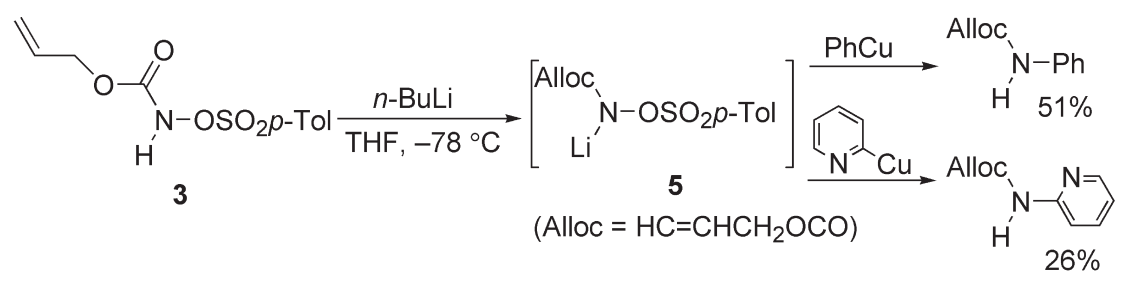

Scheme 1.2-1.5<smiles>CC1(C)O[C@@H]2Cc3ccccc3[C@H]2N1C(=O)CCc1ccccc1</smiles>

1) $n$-BuLi, $-78^{\circ} \mathrm{C}$

2) $\mathrm{CuCN},-78$ to $0^{\circ} \mathrm{C}$

3) $\mathrm{BoC}$

$\mathrm{Li}^{\prime}{ }_{4}^{\mathrm{N}-\mathrm{OSO}_{2} \mathrm{p}-\mathrm{Tol}}$<smiles>CC(C)(C)C(=O)C(Cc1ccccc1)N[13C](=O)[O-]</smiles>

Scheme 1.6

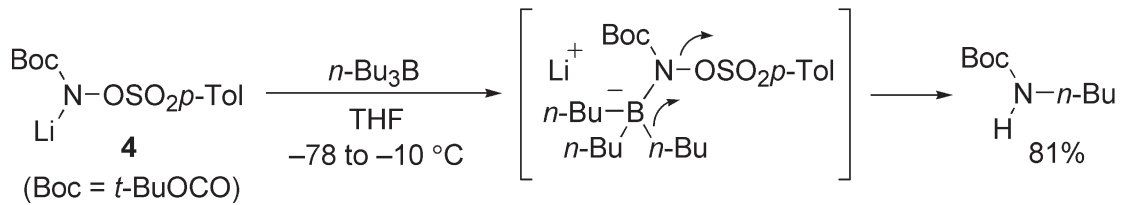

Scheme 1.7

The reaction presumably proceeds through the aniotropic rearrangement of an organoborate complex.

In addition, arylsulfonyloxycarbamates such as 6-8 can be used for aziridination of alkenes by treatment with inorganic bases such as $\mathrm{CaO}$ or $\mathrm{Cs}_{2} \mathrm{CO}_{3}$. The treatment of, for example, cyclohexene with ethyl $N$-arylsulfonyloxycarbamates $\mathbf{6}$ and 7 in the presence of $\mathrm{CaO}$ gives $N$-ethoxycarbonylaziridine along with a small amount of an allylic amination product (Scheme 1.8) [9]. As judged from the formation of an $\mathrm{sp}^{3} \mathrm{C}-\mathrm{H}$ amination product, the reactive intermediate of this reaction seems to be ethoxycarbonylnitrene. Silyl enol ethers are aminated by the same procedure to afford $\alpha$-amino carbonyl compounds, presumably via $N$ ethoxycarbonyl azirines (Scheme 1.9). 


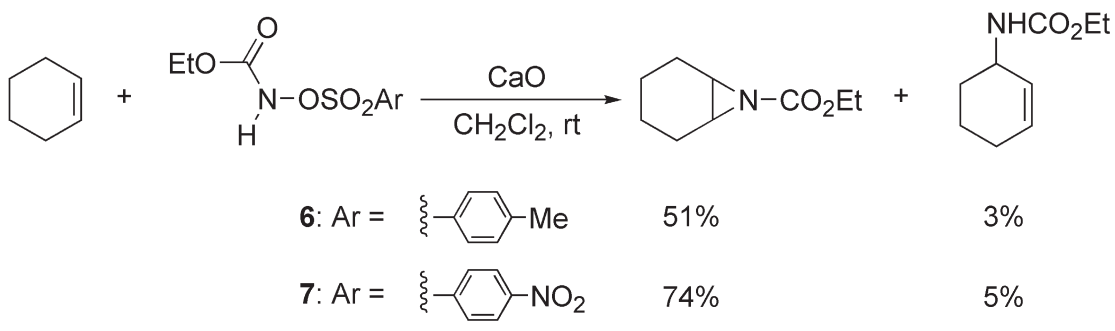

Scheme 1.8

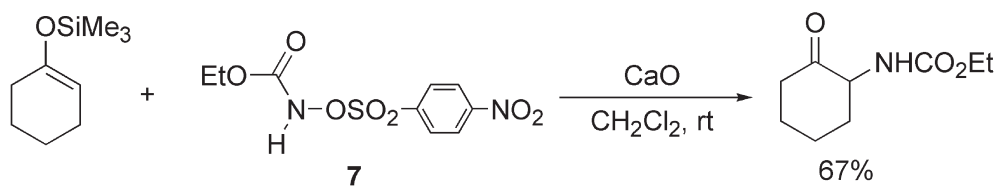

Scheme 1.9<smiles>O=[N+]([O-])C1=CCCCC1</smiles><smiles>CCOC(=O)NOOS(=O)(=O)c1ccc([N+](=O)[O-])cc1</smiles>

Scheme 1.10

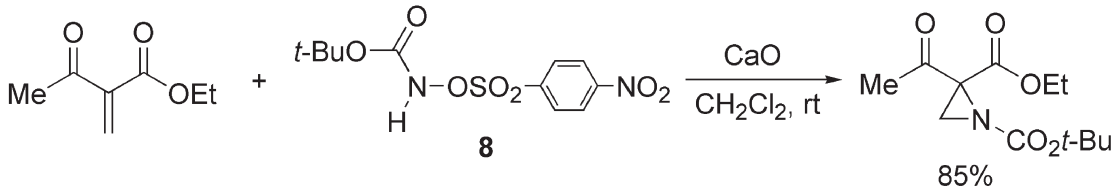

Scheme 1.11

The corresponding reactions with electron-deficient alkenes also afford aziridines, but through some other mechanism, such as an aza-Michael additionelimination process (Schemes 1.10, 1,11) [10].

\section{2 .2}

\section{O-Phosphinylhydroxylamine}

As well as $O$-sulfonyloximes (Section 1.2.1), O-(diphenylphosphinyl)hydroxylami ne (9) has also been utilized for the electrophilic amination of various carbanions to prepare primary amines [11]. Grignard reagents and organolithiums including enolates are aminated with 9 (Table 1.1).

The application of $O$-(diphenylphosphinyl)hydroxylamine (9) is limited by its low solubility in most organic solvents. Recently, Vedejs reported that $O$-di-( $p$ methoxyphenylphosphinyl)-hydroxylamine (10), which is soluble in THF even at 
Table 1.1 Electrophilic amination with O-(diphenylphosphinyl)hydroxylamine (9).

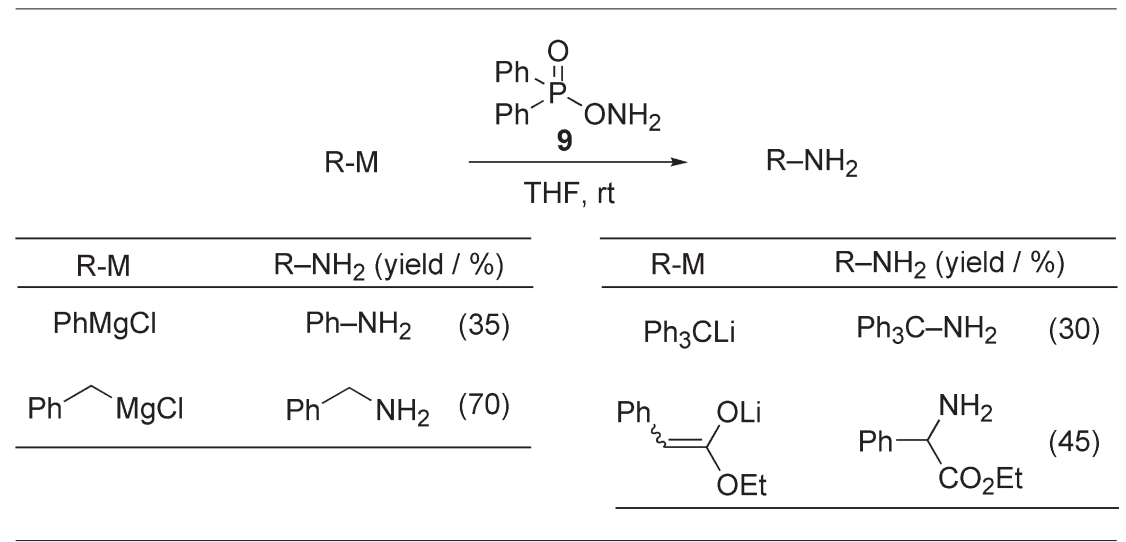

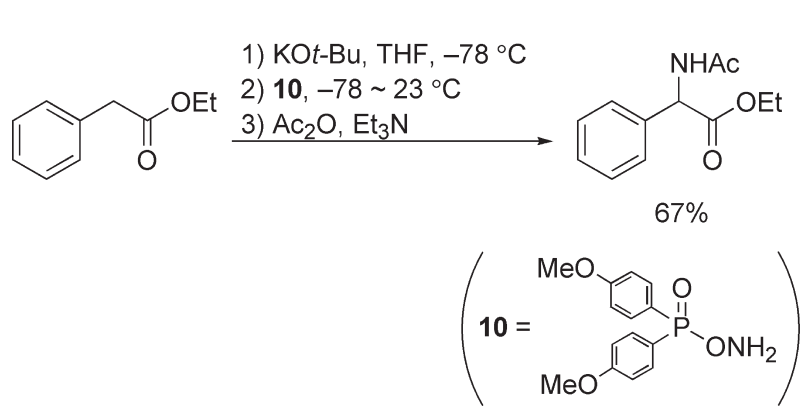

Scheme 1.12

$-78^{\circ} \mathrm{C}$, reacts efficiently with stabilized sodium or potassium enolates derived from malonates, phenylacetates, and phenylacetonitrile as shown in Scheme 1.12 [12].

\section{2 .3}

\section{O-Acylhydroxylamine}

O-Acylhydroxylamines have not been employed for electrophilic amination as extensively as $O$-sulfonyl- and $O$-phosphinylhydroxylamines [13]. Recently, though, J. S. Johnson has developed a mild and widely applicable method for the preparation of various secondary and tertiary amines through the copper-catalyzed electrophilic amination of organozinc reagents with O-benzoylhydroxylamines such as 11 or 12 [14]. The O-benzoylhydroxylamines, most of which are stable enough to be used in the subsequent amination, are prepared by the oxidation of the corresponding primary and secondary amines with benzoyl peroxide and $\mathrm{K}_{2} \mathrm{HPO}_{4}$ in DMF (Schemes 1.13 and 1.14).

Secondary and tertiary amines are synthesized by treatment of organozincs with O-benzoylhydroxylamines $\mathbf{1 1}$ and $\mathbf{1 2}$ in the presence of catalytic amounts of $[\mathrm{Cu}(\mathrm{OTf})] \cdot \mathrm{C}_{6} \mathrm{H}_{6}$ (Schemes 1.15 and 1.16). 


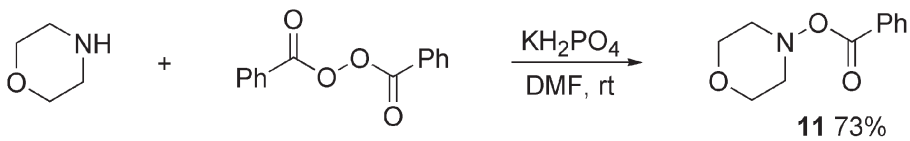

Scheme 1.13

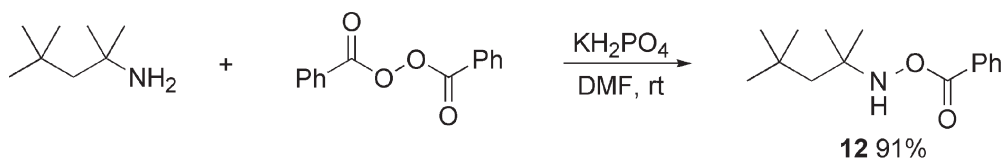

Scheme 1.14

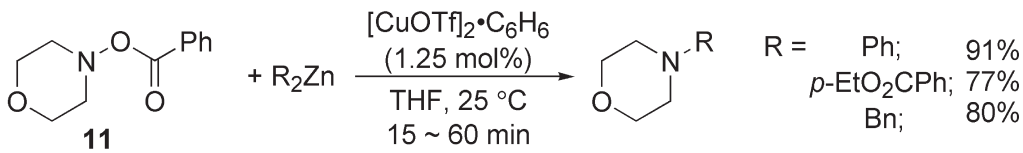

Scheme 1.15

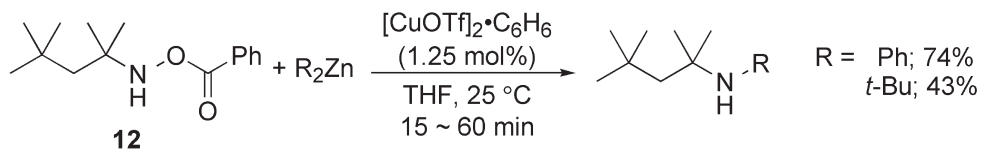

Scheme 1.16

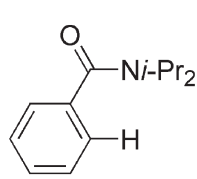

1) $s$-BuLi, TMEDA

$-78^{\circ} \mathrm{C}, 30 \mathrm{~min}$

2) $\mathrm{ZnCl}_{2}$
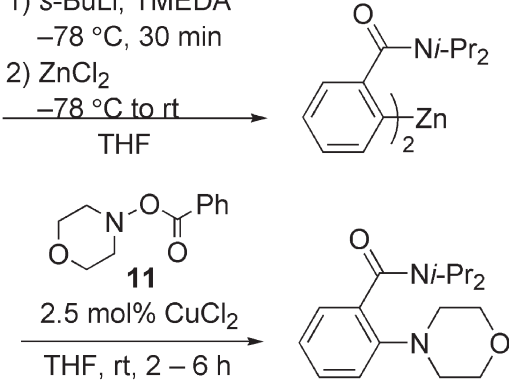

$88 \%$

Scheme 1.17

This methodology can be used for aromatic $\mathrm{C}-\mathrm{H}$ amination by combination with directed ortho-lithiation/transmetalation (Scheme 1.17).

\section{2 .4}

\section{O-Trimethylsilylhydroxylamine}

Ricci developed the electrophilic amination of higher-order cyanocuprates with N,O-bis(trimethylsilyl)hydroxylamine (13), providing a suitable method for the preparation of primary amines (Scheme 1.18) [15]. 


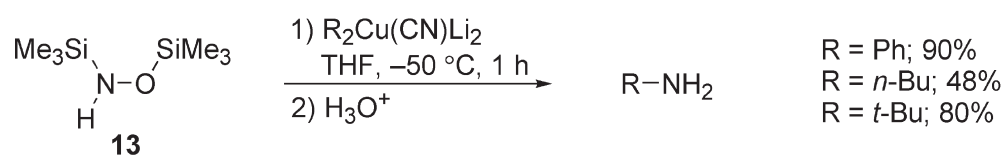

\section{Scheme 1.18}
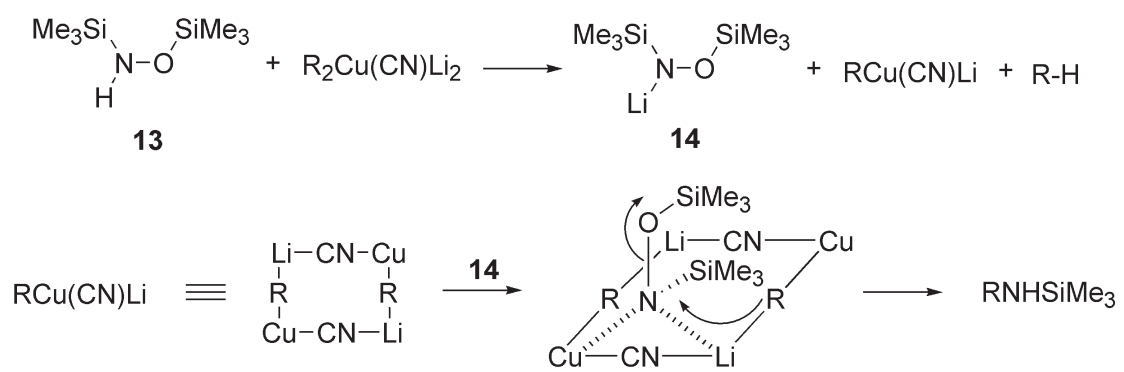

Scheme 1.19 Electrophilic amination with N,O-bis(trimethylsilyl)hydroxylamines (13).

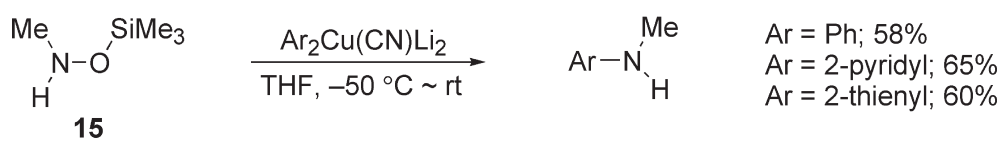

Scheme 1.20

N,O-Bis(trimethylsilyl)hydroxylamine (13) first reacts with the higher-order cuprate to generate lithium $\mathrm{N}$-silyl- $\mathrm{N}$-siloxyamide 14 and monoanionic lower-order cyanocuprate. The new $\mathrm{C}-\mathrm{N}$ bond may be formed by the interception of lithium amide 14 with the thus formed cuprate via an amide-copper intermediate as shown in Scheme 1.19.

Similarly, by starting from $\mathrm{N}$-alkyl-O-(trimethylsilyl)hydroxylamines such as $\mathbf{1 5}$, $\mathrm{N}$-alkyl aromatic and heteroaromatic amines are prepared by treatment with aryl- and heteroarylcyanocuprates (Scheme 1.20) [16].

\section{2 .5}

\section{Experimental Procedures}

Representative synthesis of O-benzoylhydroxylamines Morpholine $(5.2 \mathrm{~mL}$. $60 \mathrm{mmol}$ ) was added by syringe in one portion to a mixture of benzoyl peroxide (12.1 g, $50 \mathrm{mmol})$ and dipotassium hydrogen phosphate $(13.1 \mathrm{~g}, 75 \mathrm{mmol})$ in DMF $(125 \mathrm{~mL})$. The suspension was stirred at ambient temperature for $1 \mathrm{~h}$. Deionized water $(200 \mathrm{~mL})$ was added, and the contents were stirred vigorously for several minutes until all solids had dissolved. The organic materials were extracted with ethyl acetate $(150 \mathrm{~mL})$ and the combined extracts were washed with saturated aqueous $\mathrm{NaHCO}_{3}(100 \mathrm{~mL} \times 2)$. The aqueous fractions were combined and extracted with ethyl acetate $(100 \mathrm{~mL} \times 3)$, and the organic fractions were combined and washed with deionized water $(100 \mathrm{~mL} \times 3)$ and brine $(100 \mathrm{~mL})$, and dried over $\mathrm{MgSO}_{4}$. Volatile materials were removed in vacuo and the resulting crude mixture 
was purified by flash column chromatography, with elution with $50 \%$ ethyl acetate/ hexane, to afford 4-benzoyloxymorpholine (11, 7.71 g, $37 \mathrm{mmol}, 74 \%)$ of $>95 \%$ purity by ${ }^{1} \mathrm{H}$ NMR spectroscopy.<smiles>C1COCCN1</smiles><smiles>O=C(OOC(=O)c1ccccc1)c1ccccc1</smiles><smiles>O=C(ON1CCOCC1)c1ccccc1</smiles>

$1173 \%$

Representative electrophilic amination with O-benzoylhydroxylamines A THF solution of diphenylzinc, prepared from an ethereal solution of $\operatorname{PhMgBr}(1.0 \mathrm{M}, 1.1 \mathrm{~mL}$, $1.1 \mathrm{mmol})$ and $\mathrm{ZnCl}_{2}(75 \mathrm{mg}, 0.55 \mathrm{mmol})$ in THF $(2.0 \mathrm{~mL})$, was added by cannula in one portion to a mixture of 4-benzoyloxymorpholine $(\mathbf{1 1}, 103 \mathrm{mg}, 0.50 \mathrm{mmol})$ and $[\mathrm{CuOTf}]_{2} \cdot \mathrm{C}_{6} \mathrm{H}_{6}(3 \mathrm{mg}, 0.0056 \mathrm{mmol})$ in THF $(5.0 \mathrm{~mL})$. The resulting solution was stirred at ambient temperature for $1 \mathrm{~h}$. The reaction mixture was diluted with $\mathrm{Et}_{2} \mathrm{O}(10 \mathrm{~mL})$ and transferred into a separating funnel. The mixture was washed with saturated aq. $\mathrm{NaHCO}_{3}(10 \mathrm{~mL} \times 3)$ and the amino components were extracted with $10 \%$ aqueous $\mathrm{HCl}(10 \mathrm{~mL} \times 3)$. The aqueous extracts were basified with $10 \%$ aq. $\mathrm{NaOH}$ and the amino components were extracted with $\mathrm{CH}_{2} \mathrm{Cl}_{2}(10 \mathrm{~mL} \times 3)$. The organic fraction was washed with brine $(10 \mathrm{~mL})$, dried over $\mathrm{Na}_{2} \mathrm{SO}_{4}$, and concentrated in vacuo to afford 4-phenylmorpholine as a white solid $(80 \mathrm{mg}, 0.49 \mathrm{mmol}$, $98 \%$ ) of $>95 \%$ purity by ${ }^{1} \mathrm{H}$ NMR.<smiles>O=C(ON1CCOCC1)c1ccccc1</smiles>
11

$$
+\mathrm{Ph}_{2} \mathrm{Zn} \stackrel{\begin{array}{c}
{[\mathrm{CuOTf}]_{2} \cdot \mathrm{C}_{6} \mathrm{H}_{6}} \\
\stackrel{(1.25 \mathrm{~mol} \%)}{\mathrm{THF}, 25^{\circ} \mathrm{C}}
\end{array}}{\stackrel{\mathrm{TH}}{\longrightarrow}}
$$<smiles>O=CCN(CCO)c1ccccc1</smiles>

Representative electrophilic amination with N,O-bis(trimethylsilyl)hydroxylamine $N$, O-Bis(trimethylsilyl)hydroxylamine $(0.426 \mathrm{~mL}, 2.0 \mathrm{mmol})$, commercially available from Aldrich Chemical Co., Inc., was added dropwise at $-50^{\circ} \mathrm{C}$ to a clear brown solution of $\mathrm{Ph}_{2} \mathrm{CuCNLi}_{2}(2.0 \mathrm{mmol})$ in THF After stirring for $1 \mathrm{~h}$, the dark reaction mixture was hydrolyzed with $20 \%$ aq. $\mathrm{HCl}(30 \mathrm{~mL})$. The aqueous layer was basified with $\mathrm{NaOH}$, and aniline was extracted with $\mathrm{Et}_{2} \mathrm{O}(2 \times 20 \mathrm{~mL})$. The organic layer was washed with brine and dried over $\mathrm{Na}_{2} \mathrm{SO}_{4}$. The solvent was removed in vacuo and the resulting crude materials were purified by distillation to afford aniline (167 mg, 90\%) as a clear liquid.

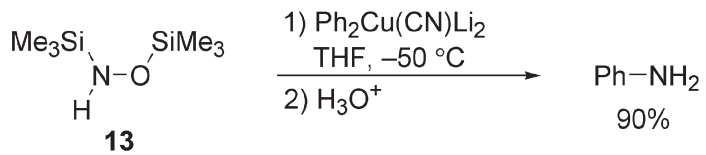




\section{Oxime Derivatives}

Oxime derivatives are readily converted into a variety of amino compounds through representative reactions such as the Beckmann rearrangement, Beckmann fragmentation, and the Neber reaction [17]. This section mainly focuses on $\mathrm{C}-\mathrm{N}$ bond formation by electrophilic amination of carbanions with oxime derivatives by substitution on the $\mathrm{sp}^{2}$ nitrogen atom.

\section{3 .1}

\section{Synthesis of Primary Amines by Electrophilic Amination of Carbanions}

Oxime $\mathrm{sp}^{2}$ nitrogen atoms possessing suitable leaving groups $\left(\mathrm{OR}^{1}\right)$ react with organometallic reagents $\left(\mathrm{R}^{3}-\mathrm{M}\right)$ to afford the corresponding $\mathrm{N}$-alkyl- or $\mathrm{N}$ arylimines, which are readily hydrolyzed to primary amines (Scheme 1.21). To make this substitution reaction efficient, competing side reactions such as the Beckmann rearrangement and the Neber reaction have to be suppressed by suitably masking the oxime derivatives.

Murdoch reported that treatment of tetraphenylcyclopentadienone O-tosyloxime (17) with excess amounts of aryllithium and aryl Grignard reagents gives $N$-arylimines, which can be converted into primary amines and cyclopentadienone oxime by treatment with excess hydroxylamine in aqueous pyridine (Scheme 1.22) [18]. The formation of the imines probably proceeds through nucleophilic addition to the nitrogen atom of oxime $\mathbf{1 7}$ to generate stabilized cyclopentadienyl anions, which undergo elimination of tosylate.

Acetone $O-(2,4,6$-trimethylphenylsulfonyl)oxime (18) can be applied in the amination of arylmagnesium and arylzinc reagents [19]. Treatment of oxime 18 under Barbier conditions (i.e., treatment of aryl bromide with 18 and magnesium in THF at reflux temperature), followed by the hydrolysis of the resulting imines under
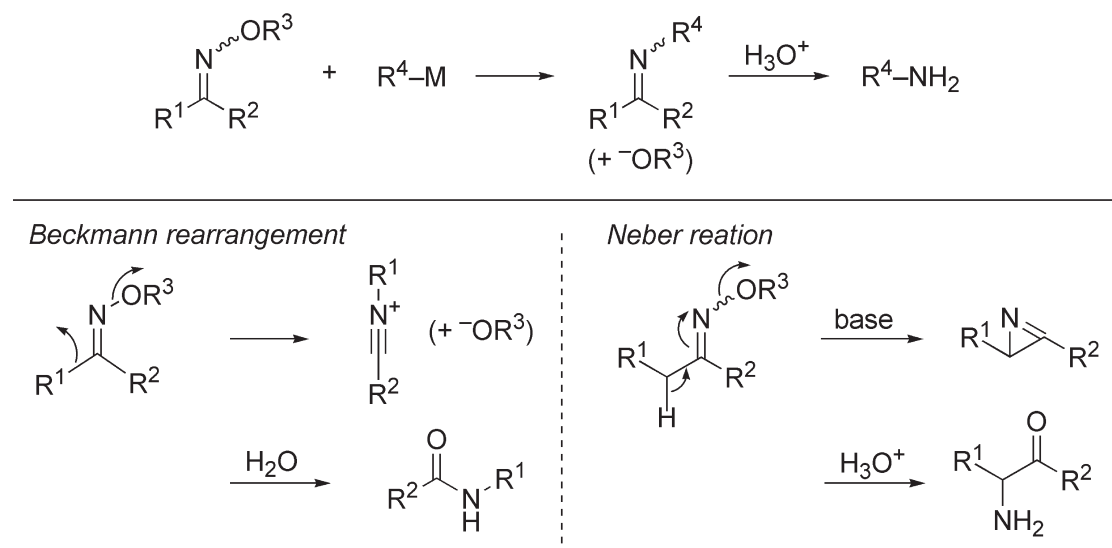

Scheme 1.21 Synthesis of primary amines by use of oxime derivatives. 
<smiles>O=S(=O)(Oc1ccccc1)Oc1ccccc1</smiles>

17<smiles>Clc1ccoc1</smiles>

THF,$-78{ }^{\circ} \mathrm{C}$<smiles></smiles><smiles>O=S(=O)(O[Na])O[Na]</smiles><smiles>c1ccc(-c2cccc(-c3ccccc3)c2-c2ccccc2)cc1</smiles><smiles>NOC1CCCC1</smiles><smiles>Nc1ccoc1</smiles>

$90 \%$<smiles>ON=C1C(c2ccccc2)=C(c2ccccc2)C(c2ccccc2)=C1c1ccccc1</smiles>

$95 \%$

Scheme 1.22 Electrophilic amination with tetraphenylcyclopentadienone O-tosyloxime (17).

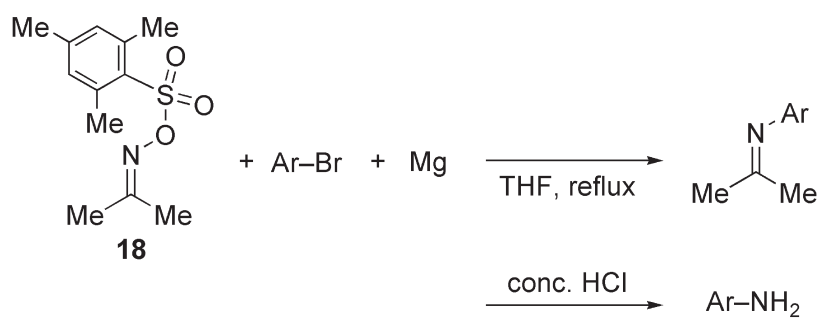

$\mathrm{Ar}=\mathrm{C}_{6} \mathrm{H}_{5} ; 52 \%$

$\mathrm{Ar}=4-\mathrm{MeOC}_{6} \mathrm{H}_{4} ; 56 \%$

$\mathrm{Ar}=1$-naphthyl; $40 \%$

Scheme 1.23 Electrophilic amination with acetone $0-(2,4,6-$

trimethylphenylsulfonyl)oxime (18).

acidic conditions, afforded $\mathrm{N}$-aryl primary amines, although the yields were moderate (40-56\%) (Scheme 1.23) [20].

Narasaka developed the amination of Grignard reagents with bis[3,5-bis(trifluo romethyl)phenyl] ketone O-tosyloxime (19) [21], the introduction of the electronwithdrawing trifluoromethyl groups suppressing the competing Beckmann rearrangements. Various primary amine derivatives are synthesized by the reaction with aryl and alkyl Grignard reagents, except in the case of tertiary alkyl reagents (Scheme 1.24).

A chiral secondary amine is prepared without loss of optical purity by treatment of a chiral Grignard reagent with oxime 19 (Scheme 1.25) [22]. This means that the reaction proceeds not through an electron-transfer mechanism but by nucleophilic substitution at the oxime nitrogen.

The employment of O-sulfonyl oximes of cyclic ureas and carbonates [23, 24] works effectively for the electrophilic amination of Grignard reagents, because they never undergo Beckmann rearrangements or Neber reactions. Among them, 4,4,5,5-tetramethyl-1,3-dioxolan-2-one $O$-(phenylsulfonyl)oxime (20), which can be 


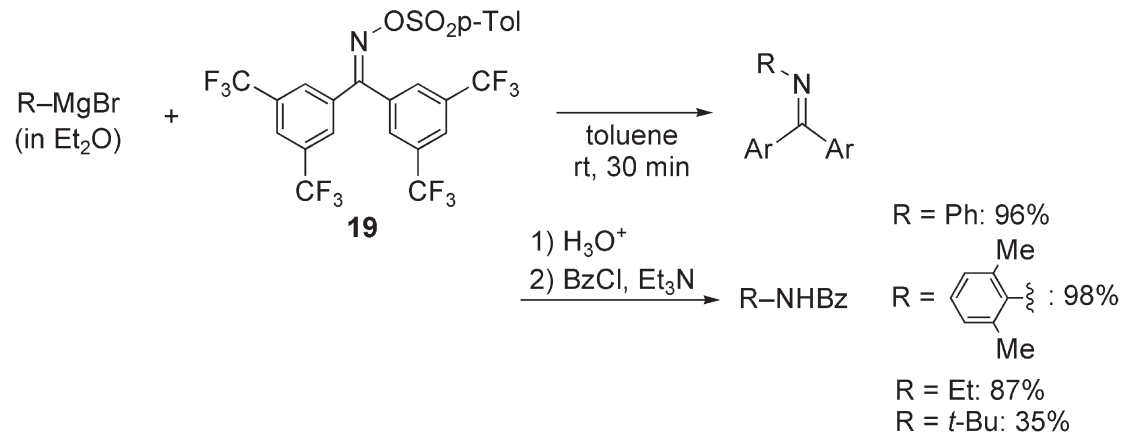

Scheme 1.24 Electrophilic amination with bis[3,5bis(trifluoromethyl)phenyl] ketone O-tosyloxime (19).

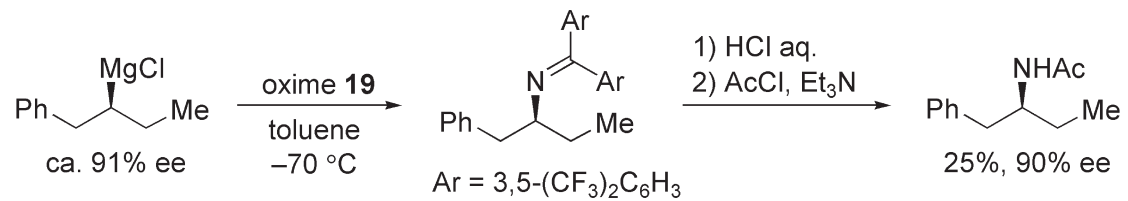

Scheme 1.25 Synthesis of a chiral secondary amine with oxime 19.

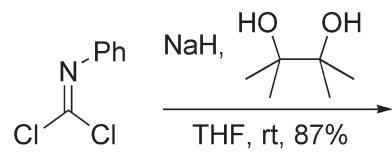<smiles>CC1(C)OC(=Nc2ccccc2)OC1(C)C</smiles>

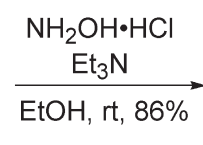<smiles>CC1(C)OC(=NO)OC1(C)C</smiles>

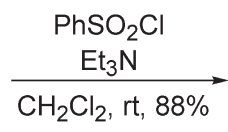<smiles>CC1(C)OC(=NOS(=O)(=O)c2ccccc2)OC1(C)C</smiles>

20

Scheme 1.26 Synthesis of 4,4,5,5-tetramethyl-1,3-dioxolan-2-one O-(phenylsulfonyl)oxime (20).

prepared easily from commercially available phenylcarbonimidic dichloride (Scheme 1.26), was found to be most suitable [25]. The imidic dichloride was treated with pinacol and $\mathrm{NaH}$ to give 2-phenylimino-1,3-dioxolane, which was transformed into $O$-(phenylsulfonyl)oxime 20 by imino-exchange by treatment with hydroxylamine followed by $\mathrm{O}$-sulfonylation of the resulting oxime.

Various Grignard reagents react with oxime 20 in nonpolar solvents to afford the corresponding imines, which are easily converted into primary amines under mild acidic conditions (Table 1.2). Aryl Grignard reagents, regardless of steric congestion and the electronic effects of the substituents on the aryl group, are smoothly aminated with $\mathbf{2 0}$, and anilines are obtained after hydrolysis or solvolysis of the resulting $N$-aryl imines. Primary, secondary, and tertiary alkylamines are 
Table 1.2 Synthesis of primary amines by the electrophilic amination of Grignard reagents with $O$-(phenylsulfonyl)oxime (20).

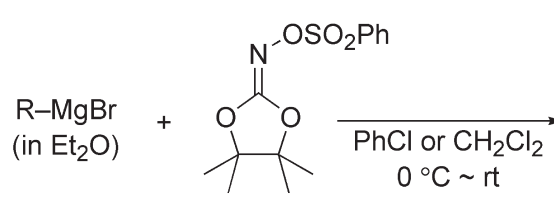

20

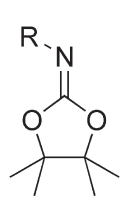

method A

: $\mathrm{HCl}$ in $\mathrm{Et}_{2} \mathrm{O}$

$\mathrm{MeOH}, \mathrm{rt}$

method $\mathrm{B}$

: $6 \mathrm{M} \mathrm{HCl}$ aq.

EtOH, reflux

\begin{tabular}{ccc}
\hline $\mathrm{R}$ & & yield / \% \\
\hline $\mathrm{Ph}$ & $\mathrm{A}$ & 93 \\
$p-\mathrm{CF}_{3}-\mathrm{C}_{6} \mathrm{H}_{4}$ & $\mathrm{~A}$ & 94 \\
$2,4-(\mathrm{MeO})_{2}-\mathrm{C}_{6} \mathrm{H}_{3}$ & $\mathrm{~A}$ & 91 \\
$2,6-\mathrm{Me}_{2}-\mathrm{C}_{6} \mathrm{H}_{3}$ & $\mathrm{~B}$ & 90 \\
\hline
\end{tabular}

\begin{tabular}{ccc}
\hline $\mathrm{R}$ & & yield /\% \\
\hline $\mathrm{PhCH}_{2} \mathrm{CH}_{2}$ & B & 90 \\
$\mathrm{PhCH}_{2} \mathrm{CH}\left(\mathrm{CH}_{3}\right)$ & B & 89 \\
1-adamantyl & B & 89 \\
$\mathrm{CH}_{2}=\mathrm{CH}\left(\mathrm{CH}_{3}\right)$ & - & $93^{\mathrm{a}}$ \\
\hline
\end{tabular}

a) Yield of 2-aza-1,3-diene.

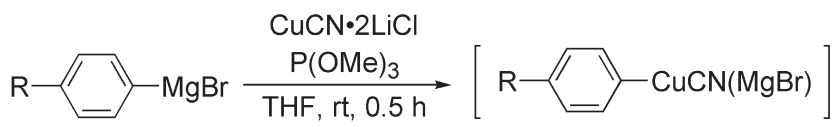<smiles>CC1(C)OC(=NOS(=O)(=O)Oc2ccccc2)OC1(C)C</smiles>

THF, rt, $0.5 \mathrm{~h}$<smiles>[R]c1ccc(N=C2OC(C)(C)C(C)(C)O2)cc1</smiles>

$\mathrm{R}=\mathrm{CO}_{2} \mathrm{Et}: 94 \%$ $\mathrm{R}=\mathrm{CN}: 92 \%$<smiles>[R]c1ccc(N[Si+]=[Si])cc1</smiles>

$\mathrm{R}=\mathrm{CO}_{2} \mathrm{Et}: 87 \%$

$\mathrm{R}=\mathrm{CN}: 91 \%$

Scheme 1.27 Electrophilic amination of arylcopper reagents with $O$-(phenylsulfonyl)oxime (20).

prepared in high yield from the corresponding alkyl Grignard reagents, and even alkenyl Grignard reagents reacted with 20 to give 2-aza-1,3-dienes.

Aryl Grignard reagents bearing a cyano or an alkoxy carbonyl group, prepared by iodine-magnesium exchange [26], cannot be used directly for this amination procedure, because of their instability at temperatures higher than $0^{\circ} \mathrm{C}$. Arylcopper reagents generated by transmetalation of such arylmagnesium compounds with $\mathrm{CuCN} \cdot 2 \mathrm{LiCl}$ in the presence of trimethyl phosphite [27] react with 4,4,5,5tetramethyl-1,3-dioxolan-2-one $O$-(phenylsulfonyl)oxime (20) to afford the corresponding $N$-arylimines, which are hydrolyzed to anilines (Scheme 1.27) [28]. 


\subsection{2}

\section{Experimental Procedures}

Procedure for the preparation of 4,4,5,5-tetramethyl-1,3-dioxolan-2-one O-phenylsulfonyloxime Pinacol $(15.2 \mathrm{~g}, 128 \mathrm{mmol})$ in THF $(60 \mathrm{~mL})$ was slowly added under argon at $0^{\circ} \mathrm{C}$ to a suspension of $\mathrm{NaH}(6.36 \mathrm{~g}, 264 \mathrm{mmol})$ in THF $(250 \mathrm{~mL})$, after which phenylcarbonimidic dichloride $(20.5 \mathrm{~g}, 128 \mathrm{mmol})$ in THF $(40 \mathrm{~mL})$ was added over $15 \mathrm{~min}$. This mixture was stirred at room temperature for $30 \mathrm{~min}$, after which the reaction was quenched with a $\mathrm{pH} 9$ ammonium buffer and the mixture was extracted three times with ethyl acetate. The combined extracts were washed with brine and dried over $\mathrm{Na}_{2} \mathrm{SO}_{4}$, and the ethyl acetate was removed in vacuo to give an $87 \%$ yield of 4,4,5,5-tetramethyl-2-phenylimino-1,3-dioxolane (22.5 g, $111 \mathrm{mmol})$, which was used without further purification.

Triethylamine $(61.7 \mathrm{~g}, 611 \mathrm{mmol})$ and $\mathrm{NH}_{2} \mathrm{OH} \cdot \mathrm{HCl}(34.1 \mathrm{~g}, 491 \mathrm{mmol})$ were added to a solution of 4,4,5,5-tetramethyl-2-phenylimino-1,3-dioxolane ( $26.7 \mathrm{~g}$, $122 \mathrm{mmol})$ in ethanol $(300 \mathrm{~mL})$, and this mixture was stirred at room temperature for $24 \mathrm{~h}$. After the reaction had been quenched with $\mathrm{pH} 9$ ammonium buffer, the mixture was extracted three times with ethyl acetate. The combined extracts were washed with water and brine and dried over $\mathrm{Na}_{2} \mathrm{SO}_{4}$, the ethyl acetate was removed in vacuo, and the crude materials were purified by flash column chromatography (hexane/ethyl acetate $1: 1$ to $1: 4$ ) to give 4,4,5,5-tetramethyl-1,3-dioxolan-2-one oxime (16.7 g, $105 \mathrm{mmol}$ ) in $86 \%$ yield.

Benzenesulfonyl chloride $(5.59 \mathrm{~g}, 31.6 \mathrm{mmol})$ in dichloromethane $(15 \mathrm{~mL})$ was slowly added under argon at $0^{\circ} \mathrm{C}$ to a solution of 4,4,5,5-tetramethyl-1,3-dioxolan2-one oxime $(4.49 \mathrm{~g}, 22.8 \mathrm{mmol})$ and triethylamine $(5.90 \mathrm{~mL}, 42.3 \mathrm{mmol})$ in dichloromethane $(100 \mathrm{~mL})$, and the mixture was stirred at room temperature for $1 \mathrm{~h}$. After the reaction had been quenched with ice water, the mixture was extracted three times with ethyl acetate, the combined extracts were washed with brine and dried over anhydrous sodium sulfate, the ethyl acetate was removed in vacuo, and the crude materials were purified by recrystallization (hexane/ethyl acetate) to give 4,4,5,5-tetramethyl-1,3-dioxolan-2-one O-phenylsulfonyloxime (20, 7.40 g, $25.9 \mathrm{mmol}$ ) in $88 \%$ yield.

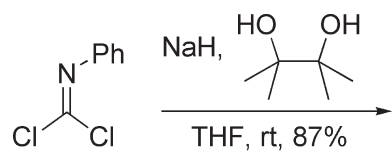<smiles>CC1(C)OC(=Nc2ccccc2)OC1(C)C</smiles>

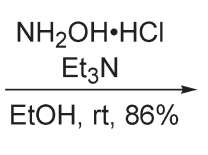<smiles>CC1(C)OC(=NO)OC1(C)C</smiles>
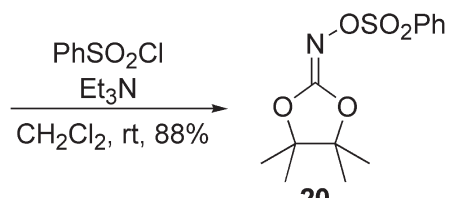
Representative procedure for the preparation of primary amine hydrochlorides by treatment of 4,4,5,5-tetramethyl-1,3-dioxolan-2-one O-phenylsulfonyloxime with Grignard reagents An ether solution of phenylmagnesium bromide $(0.96 \mathrm{M}$, $2.3 \mathrm{~mL}, 2.2 \mathrm{mmol}$ ) was added dropwise under argon at $0^{\circ} \mathrm{C}$ to a solution of 4,4,5,5tetramethyl-1,3-dioxolan-2-one $O$-phenylsulfonyloxime $(20,593 \mathrm{mg}, 1.98 \mathrm{mmol})$ in chlorobenzene $(15 \mathrm{~mL})$, and this mixture was stirred at the same temperature for $30 \mathrm{~min}$. The reaction was then quenched with $\mathrm{pH} 9$ ammonium buffer at $0{ }^{\circ} \mathrm{C}$, and the mixture was extracted three times with ethyl acetate. The combined extracts were washed with brine and dried over $\mathrm{Na}_{2} \mathrm{SO}_{4}$, and the ethyl acetate was removed under vacuum. Hydrogen chloride in ether $(1.0 \mathrm{M}, 4.0 \mathrm{~mL})$ was added at $0{ }^{\circ} \mathrm{C}$ to the crude imine in methanol $(10 \mathrm{~mL})$, and this mixture was stirred at room temperature for $1.5 \mathrm{~h}$. Volatile materials were removed in vacuo, and anhydrous ether $(40 \mathrm{~mL})$ was added. The insoluble materials were collected by filtration to give aniline hydrochloride $(239 \mathrm{mg}, 1.84 \mathrm{mmol}$ ) in $93 \%$ yield.

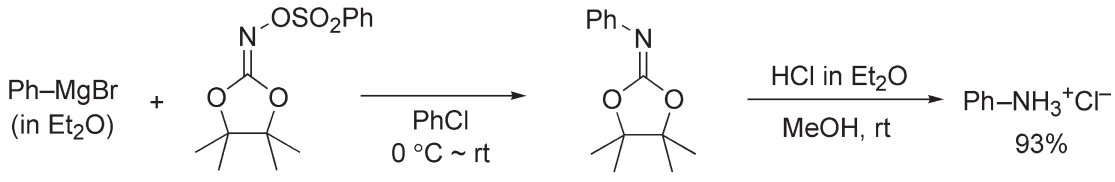

Representative procedure for the preparation of primary arylamines possessing electron-withdrawing groups by use of 4,4,5,5-tetramethyl-1,3-dioxolan-2-one 0 phenylsulfonyloxime A THF solution of isopropylmagnesium bromide $(1.15 \mathrm{M}$, $0.96 \mathrm{~mL}, 1.1 \mathrm{mmol}$ ) was slowly added under argon at $-20^{\circ} \mathrm{C}$ to a solution of ethyl 4-iodobenzoate $(278 \mathrm{mg}, 1.01 \mathrm{mmol}) \mathrm{in} \mathrm{THF}$, and this mixture was stirred at the same temperature for $30 \mathrm{~min}$. A THF solution of $\mathrm{CuCN} \cdot 2 \mathrm{LiCl}(0.50 \mathrm{M}, 2.0 \mathrm{~mL}$, $1.0 \mathrm{mmol}$ ) was then added, the temperature again being kept below $-20^{\circ} \mathrm{C}$. After completion of the addition, the reaction mixture was allowed to warm to room temperature over $30 \mathrm{~min}$. Trimethyl phosphate $(128 \mathrm{mg}, 2.0 \mathrm{mmol})$ was then added and the clear solution was stirred for an additional $5 \mathrm{~min}$. 4,4,5,5-Tetramethyl-1,3dioxolan-2-one O-phenylsulfonyloxime $(20,290 \mathrm{mg}, 0.969 \mathrm{mmol})$ in THF $(3 \mathrm{~mL})$

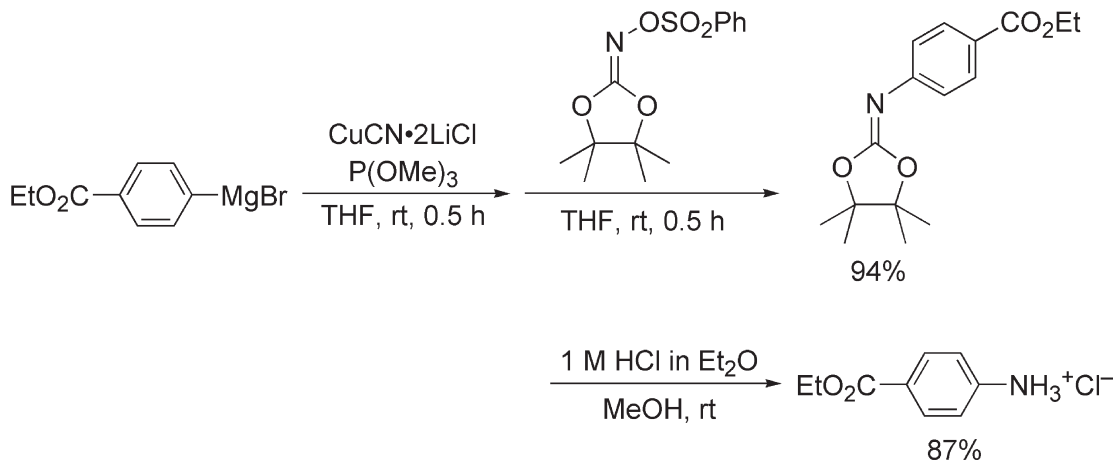


was then added dropwise and the reaction mixture was stirred at this temperature for $15 \mathrm{~min}$. After the reaction had been quenched with a $\mathrm{pH} 9$ buffer at $0^{\circ} \mathrm{C}$, the mixture was extracted three times with ethyl acetate, and the combined extracts were washed with brine and dried over anhydrous sodium sulfate. The ethyl acetate was removed under vacuum and the crude materials were purified by flash column chromatography (silica gel, hexane/ethyl acetate $8: 2$ ) to give 2-(4-ethoxycarbonylphenyl)imino-4,4,5,5-tetramethyl-1,3-dioxolane (266 mg, $0.913 \mathrm{mmol}$ ) in $94 \%$ yield. The resulting imine was converted into aniline by the same procedure as described in Section 1.3.2.

\section{4}

\section{Azo Compounds}

In this section some amination reactions utilizing azodicarboxylates (Section 1.4.1) and arylazo sulfones (Section 1.4.2) as nitrogen sources are illustrated. In the azodicarboxylate section, amination reactions of alkenes are discussed, because there are some reviews on the electrophilic amination of carbanions leading various hydrazine dicarboxylates [29].

\section{4 .1}

\section{Azodicarboxylates}

\subsubsection{Allylic Amination through Ene-Type Reactions}

Ene reactions play an important role in organic transformations, and the use of azo compounds such as diethyl azodicarboxylate (DEAD; 21) as enophiles provides a useful method for amination of alkenes (aza-ene reaction) to give allyllic hydrazines (Scheme 1.28). Although thermal aza-ene reactions of various alkenes with DEAD have been reported, such reactions generally require high temperatures and are difficult to control because of the formation of bis-adducts [30].

Leblanc improved this thermal aza-ene reaction by use of bis-(2,2,2trichloroethyl) azodicarboxylate (22) [31]. Reactions between alkenes and 22

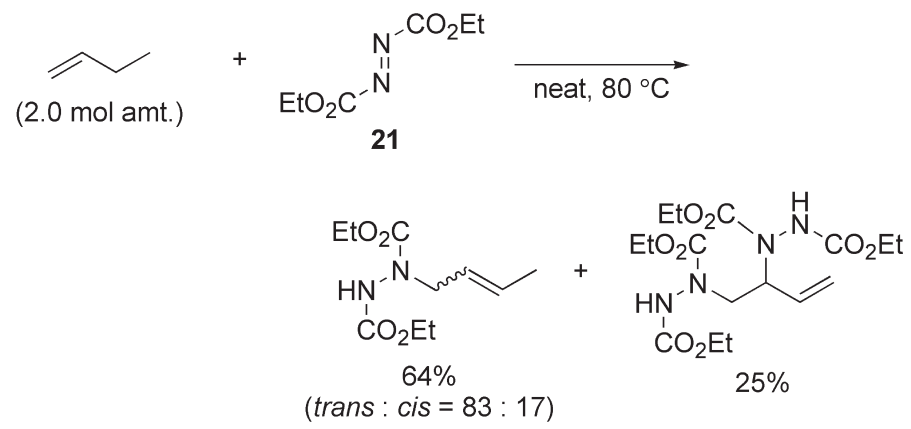

Scheme 1.28 


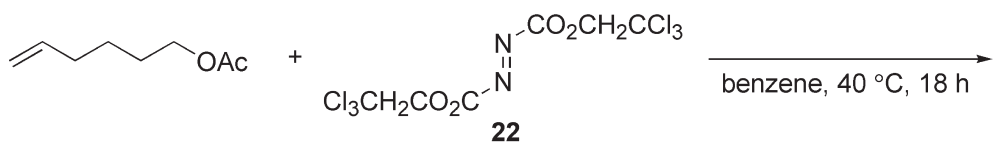

(1.2 mol amt.)

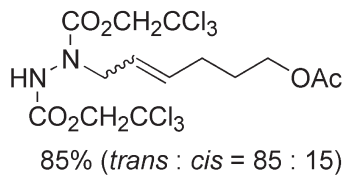

1) $\mathrm{Zn}, \mathrm{AcOH}$

2) $\mathrm{Ac}_{2} \mathrm{O}$, pyridine

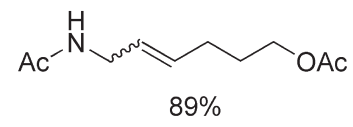

Scheme 1.29 The aza-ene reaction with bis(2,2,2-trichloroethyl) azodicarboxylate (22).

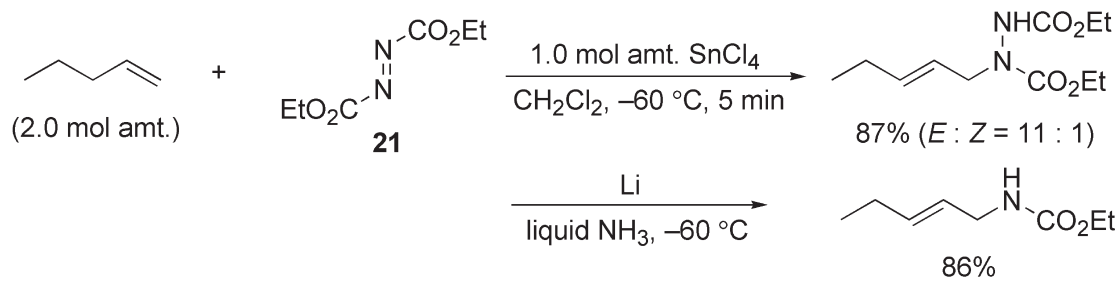

Scheme 1.30 Lewis acid-mediated allylic amination of alkenes with DEAD (21).

proceed under milder conditions to give the corresponding ene adducts in good yield without the formation of bis-adducts (Scheme 1.29). In addition, by treatment with $\mathrm{Zn}$ dust and acetic acid, the reductive cleavage of the $\mathrm{N}-\mathrm{N}$ bonds in the resulting allyllic hydrazines proceeds to give allylic amine derivatives.

Heathcock developed Lewis acid-mediated allylic amination of alkenes with DEAD (Scheme 1.30) [32]. The use of $\mathrm{SnCl}_{4}$ in dichloromethane promotes the reaction at $-60^{\circ} \mathrm{C}$, affording the ene adducts in good yield with excellent selectivity for the formation of $(E)$-alkenes. The allylic hydrazines can be converted into carbamates by treatment with lithium in liquid ammonia. In addition, $\mathrm{LiClO}_{4}$ was also able to catalyze aza-ene reactions of azodicarboxylate derivatives [33].

\subsubsection{Hydrohydrazination of Alkenes}

Carreira has recently developed the Co- and Mn-catalyzed hydrohydrazination of alkenes with azodicarboxylates, which enables the preparation of various alkylhydrazines from a broad range of alkenes [34].

Mono-, di-, and trisubstituted alkenes, including vinyl heterocycles, react with azodicarboxylates such as 23 in the presence of phenylsilane and the Co(III) catalyst 24, bearing Schiff base ligands, to give alkylhydrazines in good yields (Table 1.3). Monosubstituted, 1,1-disubstituted, and trisubstituted alkenes give exclusively the Markovnikov-type hydrohydrazination products with broad functional group tolerance. In the reaction behavior of 1,2-disubstituted alkenes, the selectivity is governed by electronic effects. Phenyl substitution results in the formation of the benzylic hydrazine, while the presence of an ethoxycarbonyl group produces an $\alpha$-hydrazinyl ester. 
Table 1.3 Co-catalyzed hydrohydrazination of alkenes with azodicarboxylate 23 .

$$
\text { alkene }+t-\mathrm{BuO}_{2} \mathrm{C}_{23}^{\mathrm{N}^{\prime}=\mathrm{N}^{\prime}} \mathrm{CO}_{2} t-\mathrm{Bu}
$$

(1.5 mol amt.)

$2.5 \sim 5$ mol\% 24

$\underset{\mathrm{EtOH}, 23^{\circ} \mathrm{C}, 4 \mathrm{~h}}{\stackrel{1 \mathrm{~mol} \text { amt. of } \mathrm{PhSiH}_{3}}{\longrightarrow}}$ alkylhydrazide
Co(III) cat. 24

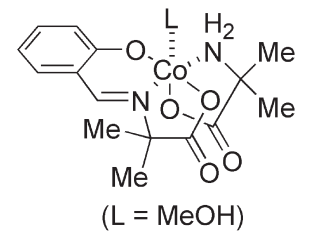

alkene
product (yield $/ \%$ )

(85)<smiles>C=CCCBr</smiles><smiles>C=Cc1cccs1</smiles><smiles>C=Cc1cc2ccccc2[nH]1</smiles><smiles>CC(=O)NC(C(C)C)C(C)CCBr</smiles>

(90)

BocHN<smiles>CC(=O)NCCCCC(C)C</smiles>

(84)<smiles>CC(c1cc2ccccc2[nH]1)[N+](=O)[O-]</smiles>

(82)

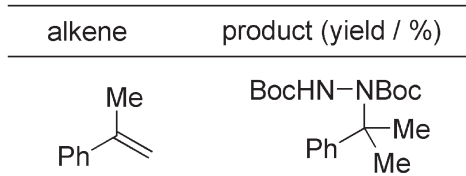

(88)<smiles>CC(C)=CCO</smiles><smiles>CC(C)(CCO)N[N+](=O)OCc1ccccc1</smiles><smiles>C/C=C/c1ccccc1</smiles><smiles>CCC(N[13C](=O)[O-])c1ccccc1</smiles>

(88)<smiles>CC=CC(=O)OCC</smiles>

(66)

The above cobalt catalyst could not be employed for the hydrohydrazination of tetrasubstituted alkenes. As an alternative, Mn(III) complex 25 exhibits high catalytic reactivity even for the hydrohydrazination of hindered alkenes such as tetrasubstituted ones (Table 1.4).

The proposed mechanism of the Co-catalyzed reaction is shown in Scheme 1.31. The first step is the formation of the active Co(III)-hydride complex I. From I, hydrocobaltation of an alkene proceeds to form Co-alkyl complex II. It is believed that this step is rate-determining, whereas the following amination step is fast. The crucial amination step from II to III could proceed either by radical addition to the $\mathrm{N}=\mathrm{N}$ double bond (path $\mathrm{A}$ ) or by direct insertion of the $\mathrm{N}=\mathrm{N}$ double bond into the Co-alkyl complex II (path B). The thus generated Co-hydrazido complex III reacts with a silane to regenerate Co-hydride complex I with the formation of silylated hydrazine derivatives, which are readily transformed into the alkylated hydrazines after ethanolysis.

This Co(III) catalyst was successfully applied to the hydrohydrazination of dienes and enynes. Although a simple reaction between di-tert-butyl 
Table 1.4 Mn-catalyzed hydrohydrazination of tetrasubstituted alkenes with azodicarboxylate 23 .

$$
\begin{aligned}
& \text { alkenes }+{ }_{t-\mathrm{BuO}_{2} \mathrm{C}_{23}^{\prime}}^{\mathrm{N}=\mathrm{N}^{\prime}} \mathrm{CO}_{2} \mathrm{t}-\mathrm{Bu} \\
& \text { (1.5 mol amt.) } \\
& 2 \text { mol\% } 25 \\
& \underset{i-\mathrm{PrOH}, 0^{\circ} \mathrm{C}}{\stackrel{1 \mathrm{~mol} \text { amt. of } \mathrm{PhSiH}_{3}}{\longrightarrow}} \text { alkylhydrazide }
\end{aligned}
$$

$\mathrm{Mn}(\mathrm{III})$ cat. 25

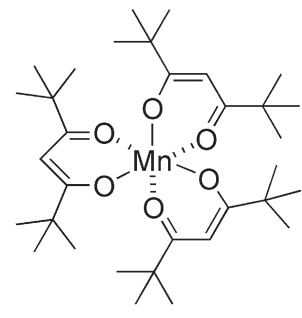

product (yield / \%)

BocHN-NBoc<smiles>CC(C)=C(C)C</smiles><smiles>CC(C)C(C)(C)[N+](=O)[O-]</smiles>

BocHN-NBoc<smiles>CC1=C(C)CCCC1</smiles><smiles>CC1(C)CCCCC1[N+](=O)[O-]</smiles>

(79)

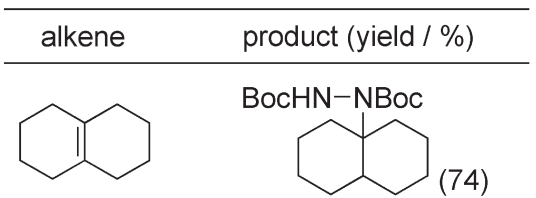<smiles>CC(C)=C(C)c1ccccc1</smiles><smiles>CC(C)C(C)(C)C(NC(=O)OCc1ccccc1)(c1ccccc1)C(C)C</smiles>

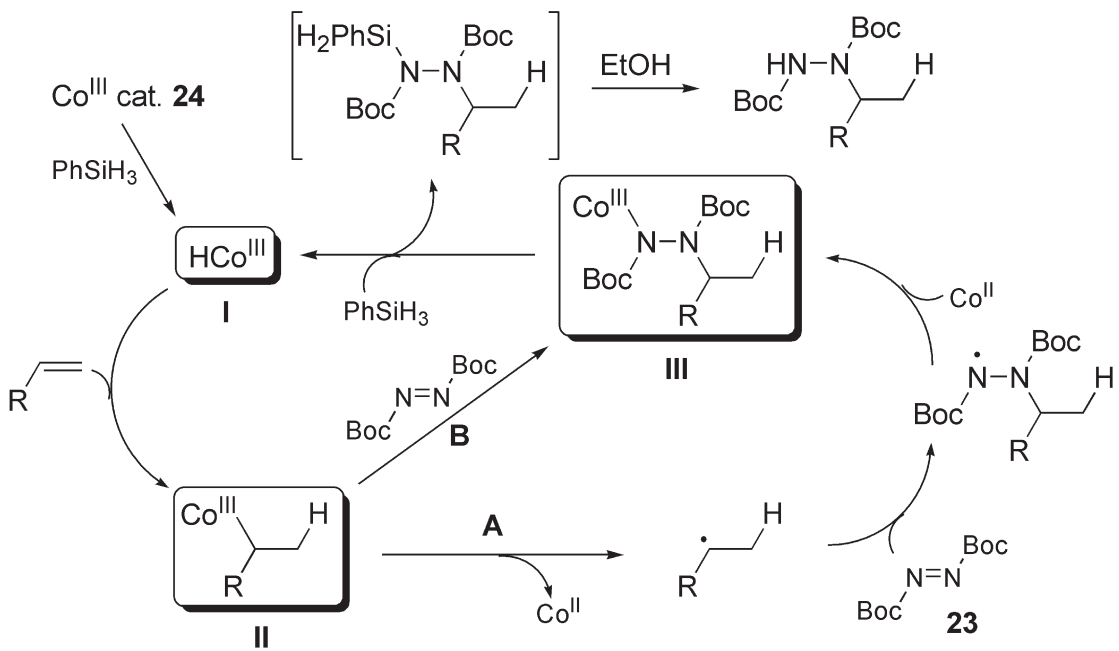

Scheme 1.31 Proposed mechanism of the hydrohydrazination of alkenes catalyzed by the Co(III) catalyst 24 . 


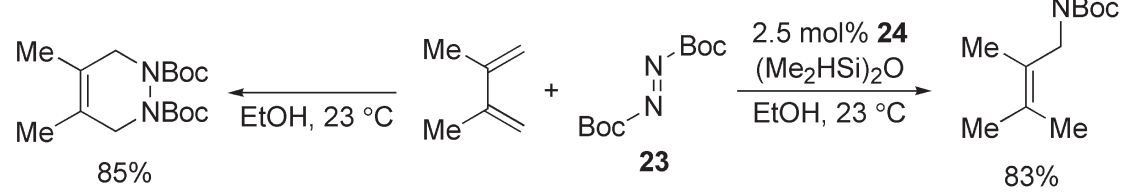

Scheme 1.32 Hydrohydrazination of dienes catalyzed by the Co(III) catalyst 24 .

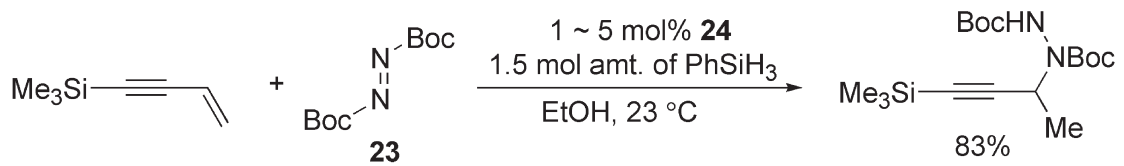

Scheme 1.33

azodicarboxylate (23) and 2,3-dimethyl-1,3-butadiene results in the formation of a $[4+2]$ adduct in $85 \%$ yield at ambient temperature [35], the reaction in the presence of $\mathrm{Co}(\mathrm{III})$ catalyst 24 and tetramethyldisiloxane results in the preferential formation of allylic hydrazine in $83 \%$ yield (Scheme 1.32). The selective formation of the primary hydrazine derivative contrasts with the same reaction with alkenes, in which the formation of Markovnikov-type products was observed.

Propargylic hydrazines can be obtained from enynes through the selective amination of the double bonds (Scheme 1.33).

\subsection{2}

\section{Arylazo Sulfones}

Arylazo p-tolyl sulfones 26 (Scheme 1.34) are readily prepared from aromatic amines in a two-step sequence consisting of the formation of the corresponding

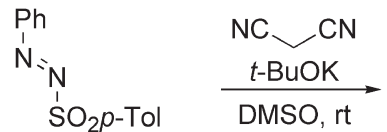

26a<smiles>N#CC(C#N)=C(C#N)Nc1ccccc1</smiles>

$87 \%$

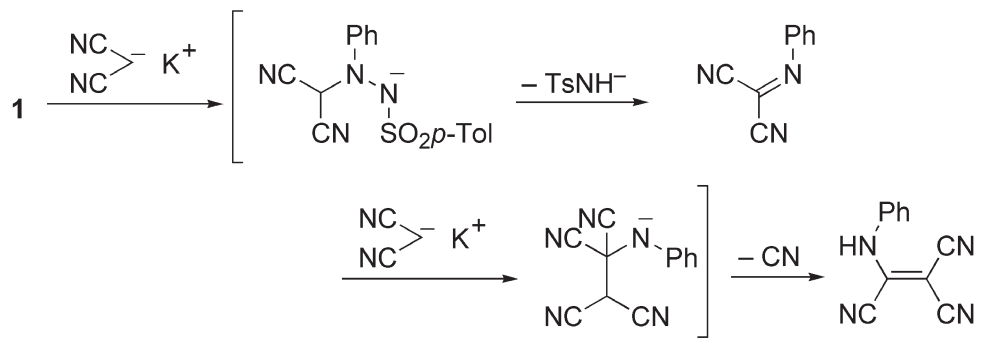

Scheme 1.34 Synthesis of tetrasubstituted ethylenes. 

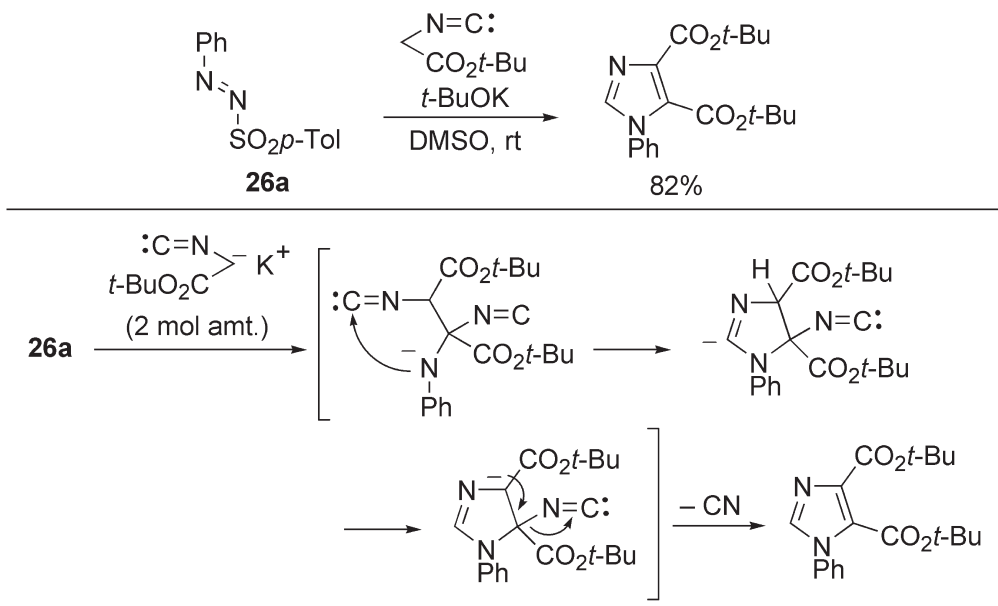

Scheme 1.35 Synthesis of tetrasubstituted 1-arylimidazoles.

arene diazonium salts and subsequent treatment with sodium $p$-tolyl sulfinate [36]. There are some reports on the synthesis of amino compounds by treatment of $\mathbf{2 6}$ with carbanions.

Potassium salts of active methylene compounds such as malononitrile react with phenylazo $p$-tolyl sulfones (26a) in DMSO to afford tetrasubstituted ethylenes bearing arylamino moieties (Scheme 1.34) [37]. Nucleophilic attack of the carbanion at the $\mathrm{N}=\mathrm{N}$ double bond of 26a and subsequent elimination of a tosylamide anion gives $\mathrm{N}$-arylimines, on which a second nucleophilic attack by the carbanion proceeds to give tetrasubstituted ethylenes.

Substituted 1-arylimidazoles can be synthesized by treatment of phenylazo $p$ tolylsulfone (26a) with (tert-butoxycarbonyl)methyl isocyanides (Scheme 1.35) [38]. After double attack of the nucleophiles as described above (Scheme 1.34), intramolecular attack at the electrophilic isocyano group carbon, aromatization through proton transfer, and elimination of cyanide ion proceed successively to give imidazoles.

Knochel identified the utility of various arylazo $p$-tolyl sulfones 26 as synthetic equivalents of $\mathrm{N}$-positively charged arylamine synthons. Arylazo $p$-tolyl sulfones 26 react under mild conditions with various polyfunctional arylmagnesium halides, and allylation of the resulting addition products, followed by treatment with zinc, provides polyfunctionalized diarylamines in good yield as shown in Table 1.5. Aliphatic magnesium halides are also aminated [39].

\section{4 .3}

\section{Experimental Procedures}

Representative procedure for the Lewis acid-mediated allylic amination of alkenes with DEAD $\mathrm{SnCl}_{4}(0.41 \mathrm{~mL}, 3.56 \mathrm{mmol})$ was added at $-60^{\circ} \mathrm{C}$ to a solution of DEAD (21, $620 \mathrm{mg}, 3.56 \mathrm{mmol})$ and pent-1-ene $(0.78 \mathrm{~mL}, 7.12 \mathrm{mmol})$ in $\mathrm{CH}_{2} \mathrm{Cl}_{2}$. After 
Table 1.5 Synthesis of diarylamines by treatment of organomagnesium compounds with aryl $p$-tolyl sulfones 26 .

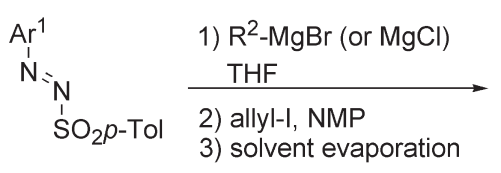<smiles>[R17]N([Al])N(C/C=C\C)S(=O)(=O)O[Na]</smiles>

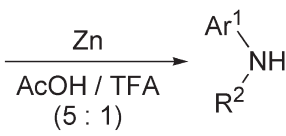

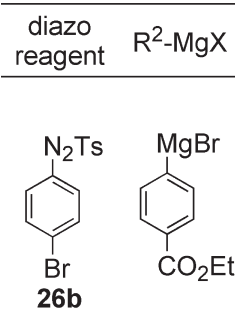

product (yield / \%)

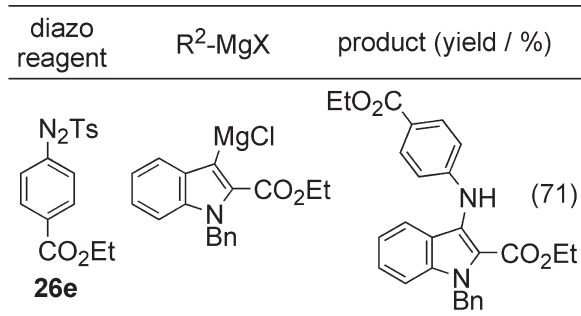<smiles>[N+]=[N+]c1ccc([N+](=O)[O-])cc1</smiles><smiles>CCOC(=O)c1ccc([N+](=O)Br)cc1</smiles><smiles>CCOC(=O)c1ccc(Nc2ccc(Br)cc2)cc1</smiles>

(83)

NC<smiles>COc1ccc([Al+])cc1</smiles><smiles>Br[Mg]c1cccc(Br)c1</smiles>

26d<smiles>CCOC(=O)c1ccc(Nc2ccc(C)cc2)cc1</smiles>

(64)

$26 b$
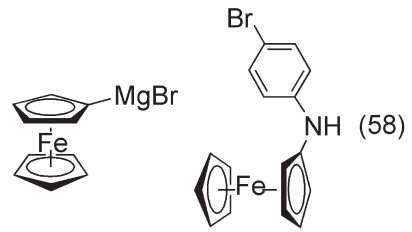

$26 b$
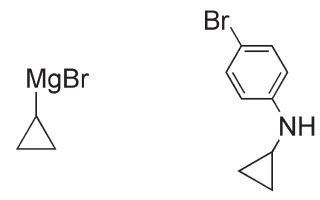

(67)

stirring for $5 \mathrm{~min}$, the yellow solution had turned colorless and water $(15 \mathrm{~mL})$ was added. The organic materials were extracted with $\mathrm{CH}_{2} \mathrm{Cl}_{2}(3 \times 50 \mathrm{~mL})$, and the combined extracts were dried over $\mathrm{Na}_{2} \mathrm{SO}_{4}$. The solvents were concentrated under vacuum to afford crude materials, which were purified by flash column chromatography (silica gel, hexane/ethyl acetate $2: 1$ ) to give $N$-(pent-2-enyl)- $N$-(ethoxycar bonyl)hydrazinecarboxylic acid ethyl ester $(760 \mathrm{mg}, 3.11 \mathrm{mmol}$ ) in $87 \%$ yield.

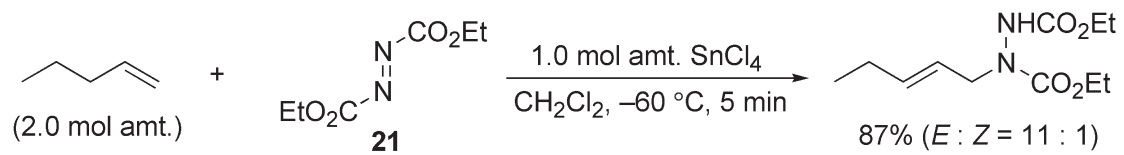

Representative procedure for the Co-catalyzed hydrohydrazination of alkenes The alkene $(75 \mu \mathrm{L}, 0.5 \mathrm{mmol})$ and phenylsilane $(65 \mu \mathrm{L}, 0.52 \mathrm{mmol})$ were added under 
argon at $23^{\circ} \mathrm{C}$ to the Co catalyst $24(10 \mathrm{mg}, 0.025 \mathrm{mmol})$ in ethanol $(2.5 \mathrm{~mL})$. Di-tertbutyl azodicarboxylate $(23,0.17 \mathrm{~g}, 0.75 \mathrm{mmol})$ was then added in one portion, and the resulting solution was stirred at $23^{\circ} \mathrm{C}$ for $4 \mathrm{~h}$. The reaction mixture was quenched with water $(1 \mathrm{~mL})$ and brine $(5 \mathrm{~mL})$ and extracted with ethyl acetate $(3 \times$ $10 \mathrm{~mL}$ ). The solvents were removed in vacuo to afford crude materials, which were purified by flash column chromatography (silica gel, hexane/ethyl acetate $10: 1$ ) to give $N$-(3-phenyl-1-methylpropyl)- $N^{\prime}$-(tert-butoxycarbonyl)hydrazinecarboxylic acid tert-butyl ester ( $155 \mathrm{mg}, 0.425 \mathrm{mmol}$ ) in $85 \%$ yield.<smiles>C=CCCc1ccccc1</smiles>

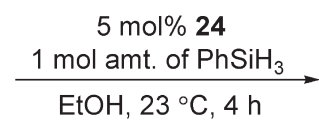

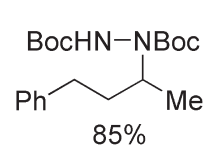

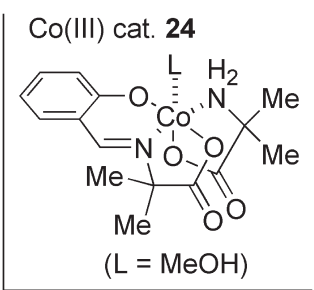

Representative preparation of arylazo tosylates: 4-bromophenylazo p-tolyl sulfone 4-Bromoaniline $(1.72 \mathrm{~g}, 10 \mathrm{mmol})$ was dissolved in an aqueous $\mathrm{HBF}_{4}$ solution $(50 \%$ in water, $15 \mathrm{~mL})$ and cooled to $0{ }^{\circ} \mathrm{C}$, and then a solution of $\mathrm{NaNO}_{2}(760 \mathrm{mg}$, $11 \mathrm{mmol})$ in water $(5 \mathrm{~mL})$ was added dropwise. After stirring for $30 \mathrm{~min}$, the reaction mixture was allowed to warm to room temperature. The resulting white precipitate was filtered off and washed with aqueous $\mathrm{HBF}_{4}$ solution $(10 \mathrm{~mL})$, ethanol $(10 \mathrm{~mL})$, and $\mathrm{Et}_{2} \mathrm{O}(20 \mathrm{~mL})$. The white crystalline powder was dissolved in $\mathrm{CH}_{2} \mathrm{Cl}_{2}$, TsNa $(2.14 \mathrm{~g}, 12 \mathrm{mmol})$ was then added, the mixture was stirred overnight, and the resulting salts were removed by filtration. The solvent was removed under vacuum, and the resulting crude materials were purified by crystallization from ethanol to give 4-bromophenylazo $p$-tolyl sulfone $(26 \mathrm{~b} ; 2.71 \mathrm{~g}, 8.0 \mathrm{mmol})$ in $80 \%$ yield (Scheme 1.36).<smiles>Nc1ccc(Br)cc1</smiles><smiles>O=[N+]([O-])O</smiles>
$\mathrm{H}_{2} \mathrm{O}, \mathrm{rt}$<smiles>Brc1ccc(N=[N+]=[I-])cc1</smiles>

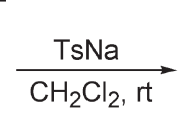<smiles>[N+]c1ccc(Br)cc1</smiles>

26b $80 \%$ (2 steps)

Scheme 1.36

Representative procedure for the amination of arylmagnesium reagents with arylazo tosylates A THF solution of $i-\operatorname{PrMgCl}(0.95 \mathrm{M}, 1.15 \mathrm{~mL}, 1.1 \mathrm{mmol})$ was added dropwise at $-20^{\circ} \mathrm{C}$ to a solution of ethyl 4-iodobenzoate $(306 \mathrm{mg}, 1.1 \mathrm{mmol})$ in THF $(5 \mathrm{~mL})$. After the mixture had been stirred for $30 \mathrm{~min}$, a solution of 4-bromophenylazo tosylate $(\mathbf{2 6 b}, 339 \mathrm{mg}, 1 \mathrm{mmol})$ in THF $(3 \mathrm{~mL})$ was added dropwise to the solution of the Grignard reagent, and the reaction mixture was stirred for $1 \mathrm{~h}$ at $-20^{\circ} \mathrm{C}$. The mixture was treated with allyl iodide $(510 \mathrm{mg}, 3 \mathrm{mmol})$ and NMP 
( $N$-methyl-2-pyrrolidone; $2 \mathrm{~mL}$ ), and stirred for $2 \mathrm{~h}$ at room temperature. After the solvent had been removed under vacuum, the resulting residue was dissolved in glacial acetic acid $(10 \mathrm{~mL})$. Zn powder $(10 \mathrm{mmol})$ and trifluoroacetic acid $(2 \mathrm{~mL})$ were added to the mixture, which was then heated at $75^{\circ} \mathrm{C}$ until no starting material was evident by TLC analysis $(2 \mathrm{~h})$. After cooling to room temperature, the mixture was poured into crushed ice (ca. $30 \mathrm{~g}$ ) and aqueous $\mathrm{NaOH}(2 \mathrm{M}, 20 \mathrm{~mL})$. The organic materials were extracted three times with $\mathrm{Et}_{2} \mathrm{O}(30 \mathrm{~mL})$ and the combined extracts were washed with saturated aqueous $\mathrm{NaHCO}_{3}$ and brine. The solvent was removed in vacuo, and the resulting residue was purified by flash column chromatography (silica gel, pentane/ $\mathrm{Et}_{2} \mathrm{O} 9: 1$ ) to give ethyl 4-(4-bromoph enylamino)benzoate ( $265 \mathrm{mg}, 0.83 \mathrm{mmol}$ ) in $83 \%$ yield as a colorless solid.

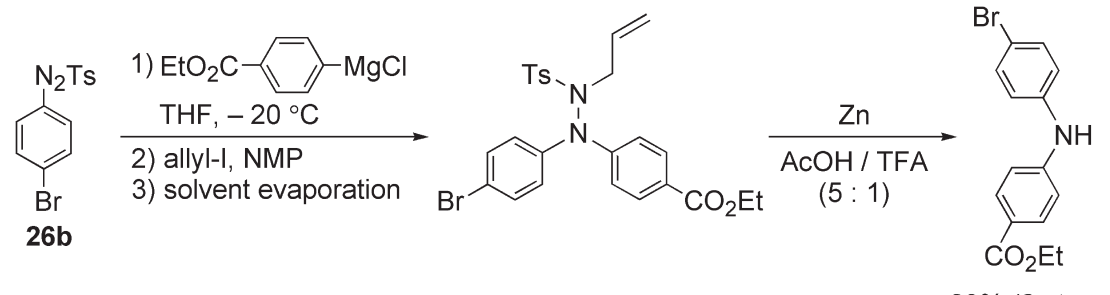

$83 \%$ (2 steps)

1.5

Oxaziridine Derivatives

Oxaziridines exhibit unique reactivity as a result of their ring strain and their relatively weak $\mathrm{N}-\mathrm{O}$ bonds. They are utilized either as amination or as oxygenation reagents of nucleophiles. The site of nucleophilic attack (at the $\mathrm{N}$ or the $\mathrm{O}$ atom) in an oxaziridine is governed by the substituent at the nitrogen [40, 41].

\subsection{1}

\section{Electrophilic Amination of Carbon Nucleophiles}

$N$-Alkoxy- or -aminocarbonyl oxaziridines, easily prepared by treatment of the corresponding imines with $m \mathrm{CPBA} / n$ - $\mathrm{BuLi}$, are used as aminating reagents of enolate anions [42]. $N$-Carboxamide oxaziridine 27, for example, is used for the $\alpha$ amination of various enolate anions in good to moderate yields (Table 1.6) [43]. These $\mathrm{N}$-transfer reactions contrast sharply with those of $\mathrm{N}$-sulfonyloxaziridines, which give $\alpha$-hydroxylated product exclusively [40].

\subsection{2}

\section{Amination of Allylic and Propargylic Sulfides by Use of a} Ketomalonate-Derived Oxaziridine

Armstrong found that amination of sulfides proceeded with the oxaziridine 28, derived from 2-oxomalonate, to afford a wide range of sulfimides (Scheme 1.37) [44]. 
Table 1.6 Electrophilic amination of lithium enolates with oxaziridine $\mathbf{2 7}$.

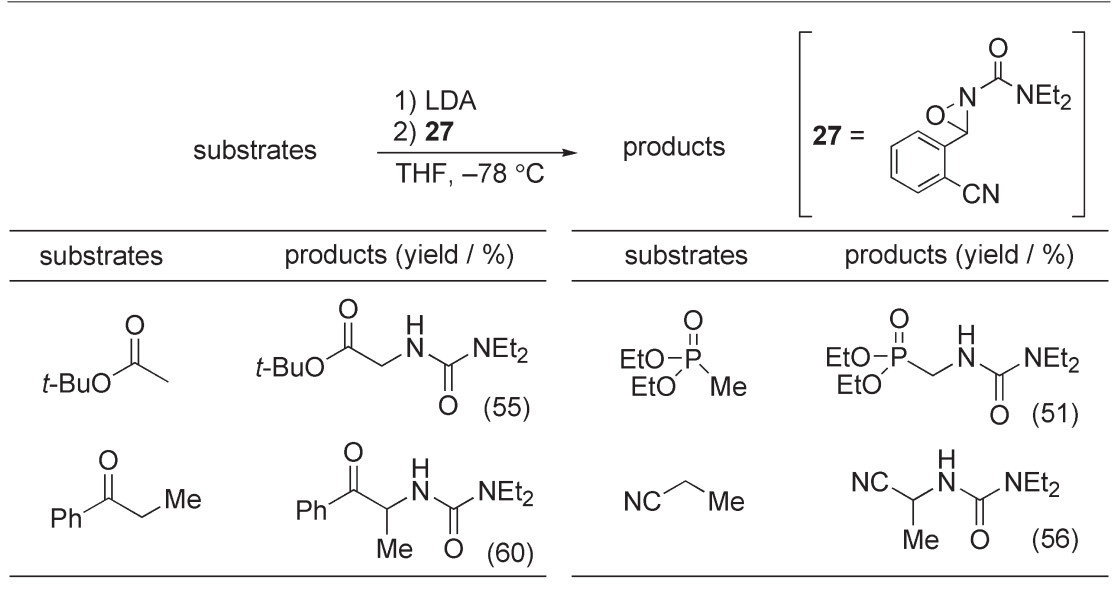

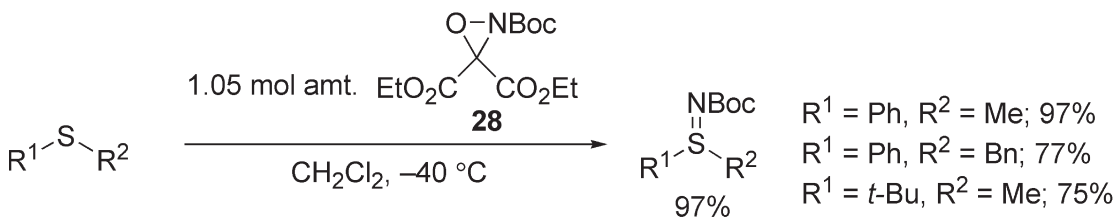

Scheme 1.37
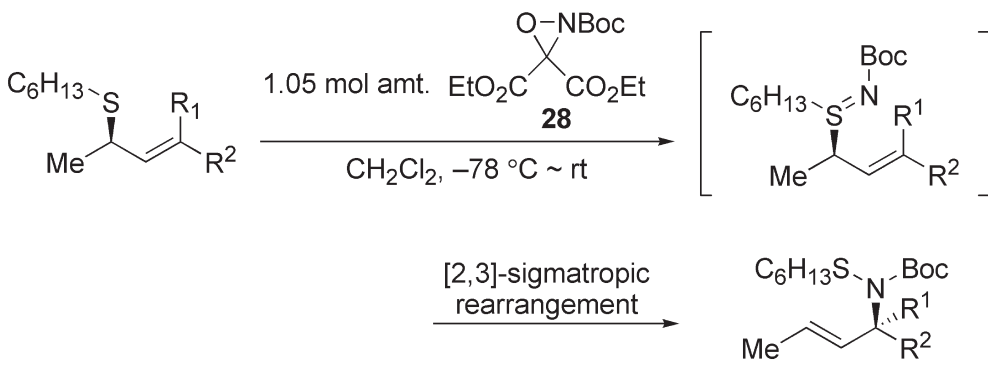

$$
\begin{aligned}
& \mathrm{R}^{1}=\mathrm{H}, \mathrm{R}^{2}=\mathrm{Me} ; 69 \%,>95 \% \text { ee } \\
& \mathrm{R}^{1}=\mathrm{H}, \mathrm{R}^{2}=\mathrm{CO}_{2} \mathrm{Me} ; 72 \%,>95 \% \text { ee } \\
& \mathrm{R}^{1}=\mathrm{Me}, \mathrm{R}^{2}=\mathrm{CO}_{2} \mathrm{Et} ; 77 \%,>94 \% \text { ee }
\end{aligned}
$$

Scheme 1.38 Synthesis of allylic amine derivatives by the $[2,3]$-sigmatopic rearrangement of allylic sulfides.

By this method, allyl amine derivatives are prepared from allylic sulfides through the rapid [2,3]-sigmatropic rearrangement of the resulting sulfimides (Scheme 1.38). A high level of chirality transfer is observed in this rearrangement and a quaternary stereocenter is successfully constructed [45]. 


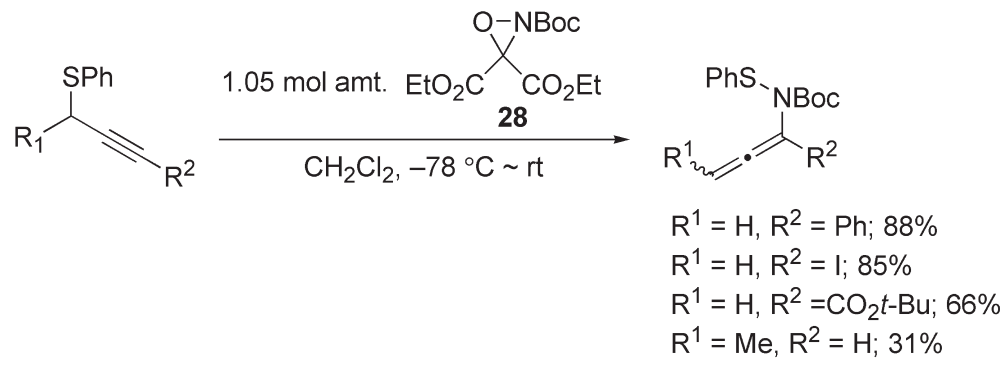

Scheme 1.39

Amination of propargylic sulfides with oxaziridine 28 gives aminoallene derivatives (Scheme 1.39) [46].

\subsection{3}

\section{Experimental Procedures}

Representative electrophilic amination of an enolate with $\mathbf{N}$-carboxamido oxaziridine $n$-BuLi $(2.5 \mathrm{M}, 0.21 \mathrm{~mL}, 0.53 \mathrm{mmol})$ was added at $0{ }^{\circ} \mathrm{C}$ to a solution of diisopropylamine $(77 \mu \mathrm{L}, 0.55 \mathrm{mmol})$ in THF $(0.85 \mathrm{~mL})$, and the mixture was stirred for $30 \mathrm{~min}$ and then cooled to $-78^{\circ} \mathrm{C}$. A solution of tert-butyl acetate $(67 \mu \mathrm{L}, 0.50 \mathrm{~mol})$ in THF $(0.85 \mathrm{~mL})$ was slowly added to the mixture, which was then stirred at $-78^{\circ} \mathrm{C}$ for $1 \mathrm{~h}$. A solution of oxaziridine $27(123 \mathrm{mg}, 0.50 \mathrm{mmol})$ was added in a single portion, and the mixture was stirred at $-78^{\circ} \mathrm{C}$ for $3 \mathrm{~h}$ before being allowed to reach room temperature over $90 \mathrm{~min}$. The reaction was quenched with saturated aqueous $\mathrm{Na}_{2} \mathrm{CO}_{3}$, and diluted with $\mathrm{CH}_{2} \mathrm{Cl}_{2}$. The organic materials were extracted with $\mathrm{CH}_{2} \mathrm{Cl}_{2}$, and the combined extracts were washed with saturated aqueous $\mathrm{Na}_{2} \mathrm{CO}_{3}$ and brine. The solvents were removed under vacuum, and the resulting residue was purified by flash column chromatography to give the desired product $(63.5 \mathrm{mg}$, $0.28 \mathrm{mmol}$ ) in $55 \%$ yield.<smiles>CCNC(=O)NCC(=O)OCC(C)(C)C</smiles><smiles>CCNC(=O)N(CC)c1ccccc1C#N</smiles>

Representative procedure for the [2,3]-sigmatropic rearrangement of an allylic sulfide The allylic sulfide $(190 \mathrm{mg}, 0.823 \mathrm{mmol})$ in $\mathrm{CH}_{2} \mathrm{Cl}_{2}(0.16 \mathrm{M})$ was added dropwise to a solution of oxaziridine $28(250 \mathrm{mg}, 0.86 \mathrm{mmol})$ in $\mathrm{CH}_{2} \mathrm{Cl}_{2}(0.18 \mathrm{M})$. The resulting solution was allowed to warm to room temperature over $30 \mathrm{~min}$, and the solvent was removed under vacuum. The resulting residue was purified by flash column chromatography (petroleum ether/ethyl acetate 20:1) to give the desired product ( $205 \mathrm{mg}, 0.593 \mathrm{mmol}$ ) in $72 \%$ yield (Scheme 1.40 ). 
<smiles>CC(=O)/C=C/C(C)SSc1ccccc1</smiles>

Scheme 1.40

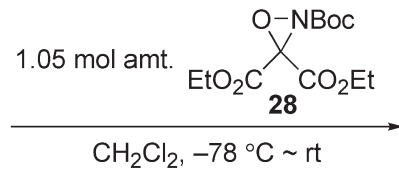

$\mathrm{CH}_{2} \mathrm{Cl}_{2},-78^{\circ} \mathrm{C} \sim \mathrm{rt}$

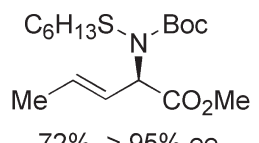

$72 \%,>95 \%$ ee

1.6

\section{Chloramine-T}

Chloramine-T ( $N$-chloro- $N$-sodio- $p$-toluenesulfonamide; 29), a well known commercially available oxidizing reagent, serves as a source of chloronium cation and nitrogen anion [47]. Chloramine-T has been synthetically applied to a wide variety of $\mathrm{C}-\mathrm{N}$ bond-forming reactions.

\subsection{1}

\section{Aminochalcogenation of Alkenes}

Diphenyl disulfide and diphenyl diselenide react with chloramine-T (29) to afford the reactive species 30, which gives aminosulfenylated (or selenylated) intermediates (Scheme 1.41). Subsequent reduction with $\mathrm{NaBH}_{4}$ gives phenylthio(or seleno)$\mathrm{N}$-tosylamines [48]. The insensitivity of this reaction to molecular oxygen and the exclusive formation of the trans products are strongly suggestive of ionic addition via sulfo(seleno)nium species.

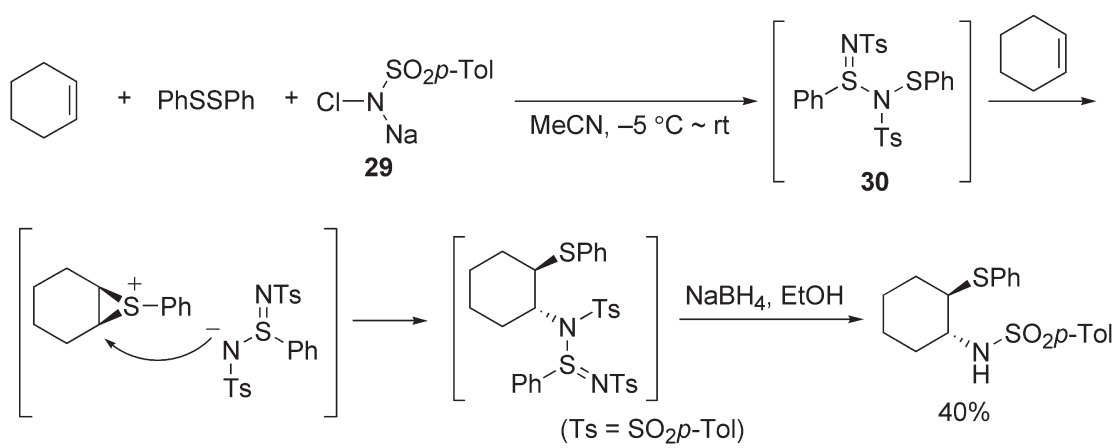

Scheme 1.41 Aminochalcogenation of alkenes by chloramine-T (29).

\subsection{2}

\section{Aminohydroxylation of Alkenes}

Treatment of alkenes with chloramine-T (29) in the presence of a catalytic amount of osmium tetroxide provides a convenient and general method for vicinal oxyamination of alkenes (Scheme 1.42) [49], which represents a significant improvement 

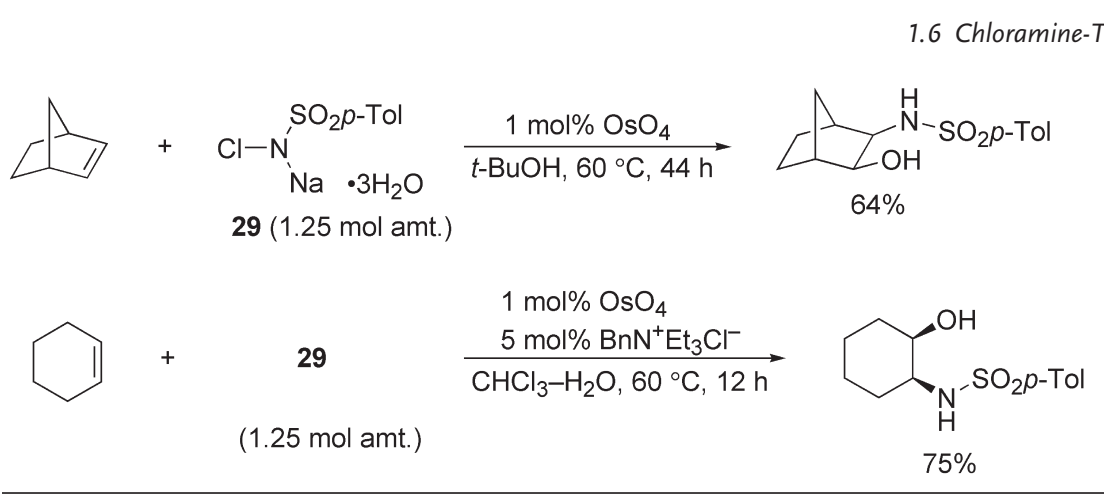

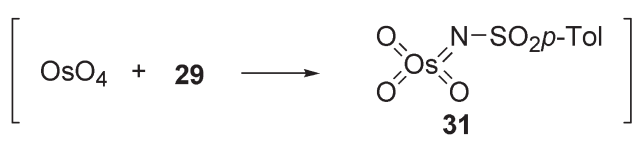

Scheme $1.42 \mathrm{OsO}_{4}$-catalyzed aminohydroxylation of alkenes by chloramine-T (29).

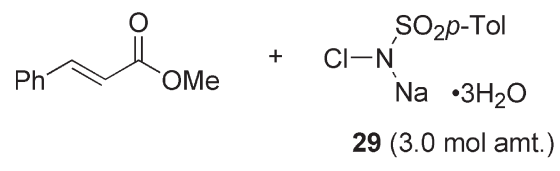

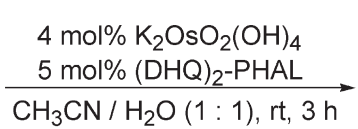

$\underset{\mathrm{CH}_{3} \mathrm{CN} / \mathrm{H}_{2} \mathrm{O}(1: 1), \mathrm{rt}, 3 \mathrm{~h}}{\longrightarrow}$<smiles>COC(=O)[C@H](O)[C@H](NC(=O)O[Na])c1ccccc1</smiles>

$64 \%, 81 \%$ ee

\section{Scheme 1.43}

over the stoichiometric oxyamination reactions [50]. This reaction is an aza analogue of the catalytic dihydroxylation of alkenes. The sulfonylimido osmium 31 is proposed as the key species.

This method has been extended to the practical asymmetric version of oxyamination through the use of dihydroquinine (DHQ) alkaloids and dihydroquinidine (DHQD) alkaloids as chiral ligands (Scheme 1.43) [51].

$\mathrm{N}$-Halocarbamate salts such as 32 can be employed in place of chloramine-T (29) for oxyamination reactions of alkenes (Scheme 1.44). The N-chloro benzyloxycarbamate salt 32 is prepared in situ from benzylcarbamate, $\mathrm{NaOH}$, and tert-butyl hypochlorite [52].

This method has been applied to the syntheses of nitrogen-containing natural products [53] such as ustiloxin D (Scheme 1.45) [53a].

\section{6 .3}

\section{Aziridination of Alkenes}

Aziridines can be used as synthetic intermediates in the preparation of nitrogencontaining compounds through ring-opening and ring-expansion reactions. In 


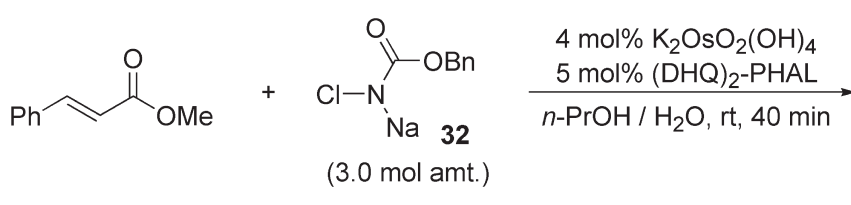<smiles>COC(=O)C(O)C(NC(=O)OCc1ccccc1)c1ccccc1</smiles>

$65 \%, 94 \%$ ee

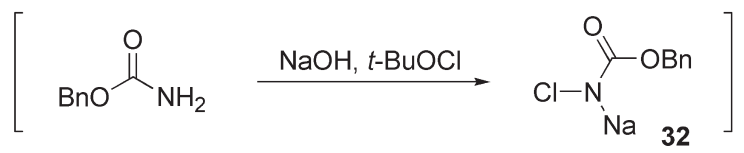

Scheme 1.44 Aminohydroxylation of alkenes with $\mathrm{N}$-halocarbamate salt (32).
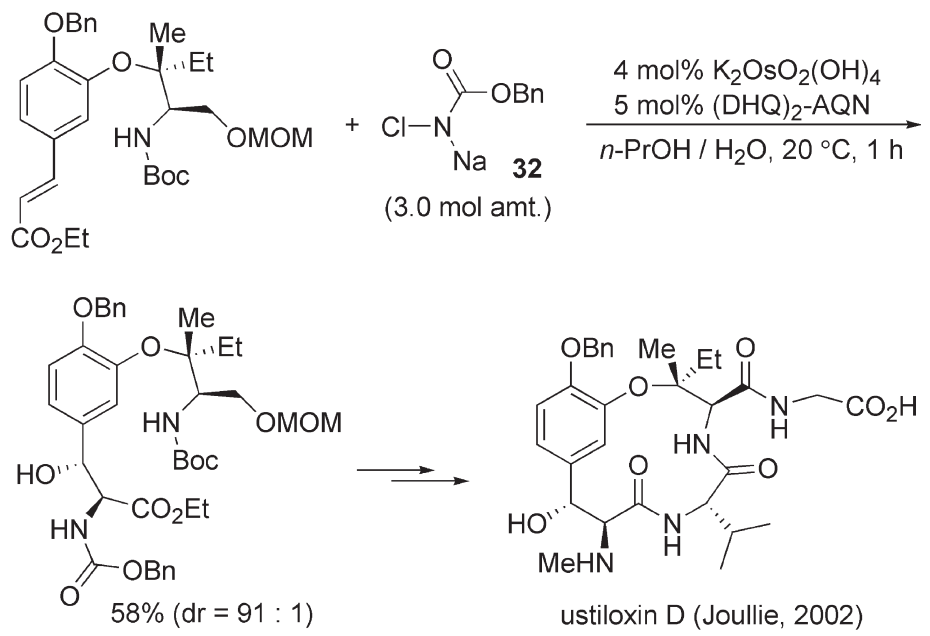

Scheme 1.45 Application of aminohydroxylation with $\mathrm{N}$ -

halocarbamate salt 32 to the synthesis of ustiloxin D.

addition, aziridines are often found in natural products, most of which show potent and diverse biological activities. There have been many reports on the synthesis of aziridines from alkenes by the use of chloramine-T (29).

In 1998, Komatsu reported the first example of aziridination of alkenes with chloramine-T (29) by use of $\mathrm{CuCl}$ as a catalyst [54]. When anhydrous chloramine-T (29) was added to $\mathrm{CH}_{3} \mathrm{CN}$ solutions of various alkenes in the presence of catalytic amount of $\mathrm{CuCl}$ and $\mathrm{MS}(5 \AA)$, the corresponding aziridines were obtained in moderate to good yields (Scheme 1.46). The same types of aziridination also proceed on employment of a CuOTf-N-(2-pyridinylmethylene)-1-pentanamine complex (Scheme 1.47) [55] or an iron(IV) corrole catalyst [56].

The combination of chloramine-T (29) and $\mathrm{AgNO}_{3}$ is utilized in the synthesis of aziridines from various alkenes, including electron-deficient alkenes such as $\alpha, \beta$-unsaturated ketones and esters (Table 1.7) [57]. The following experimental evidence suggests that the reaction might involve a nitrogen radical species 


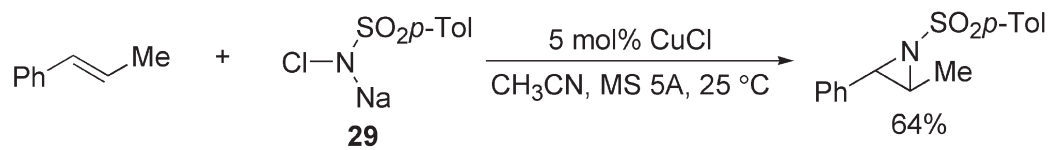

\section{Scheme 1.46}

Scheme 1.46

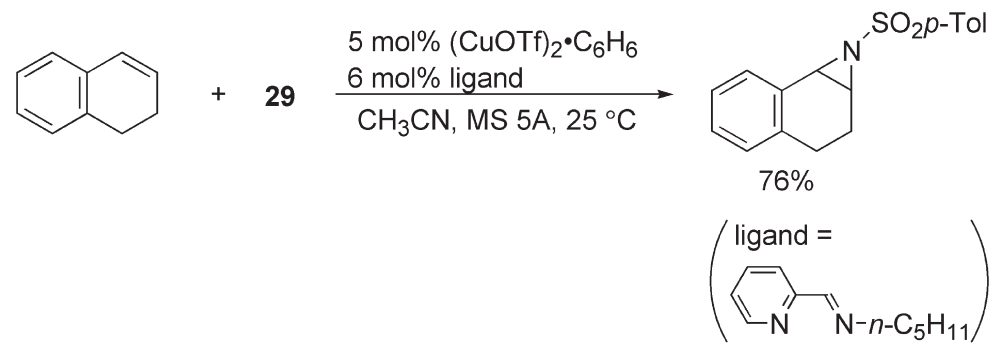

Scheme 1.47

Table 1.7 $\mathrm{AgNO}_{3}$-mediated aziridination of alkenes with chloramine-T (29).

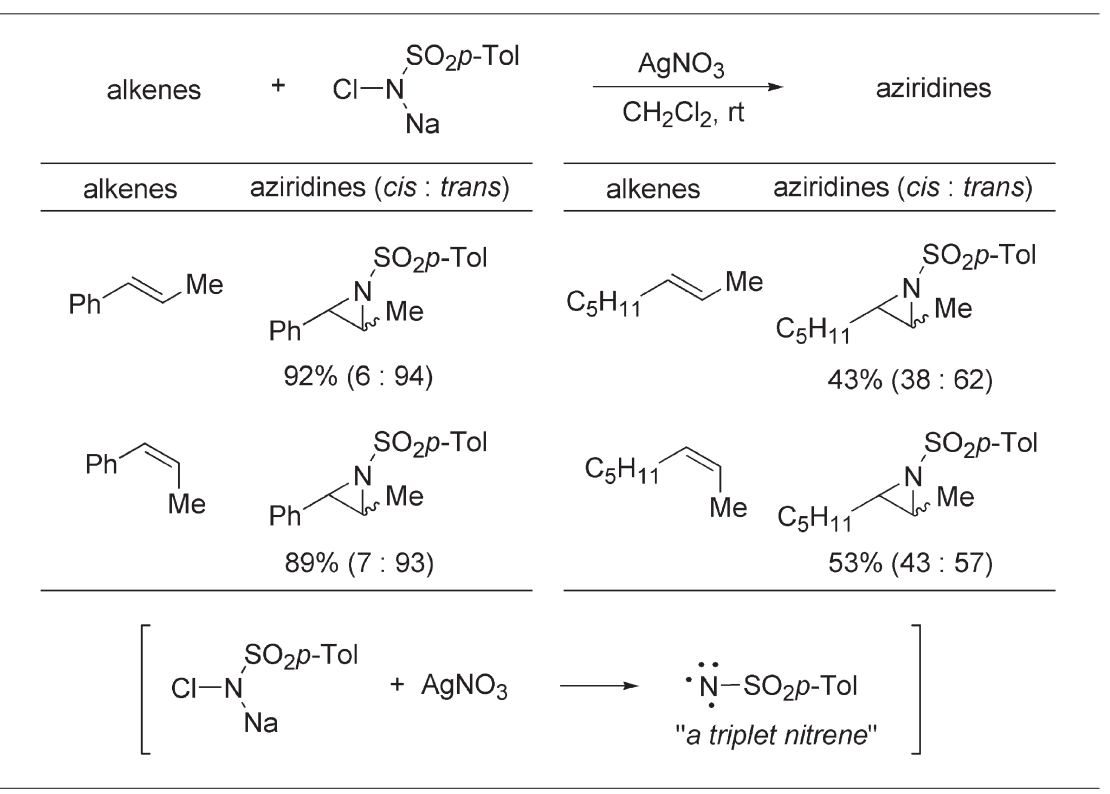

(a triplet nitrene). 1) This aziridination did not proceed at all under an oxygen atmosphere (Scheme 1.48). 2) Treatment of 1,4-dioxane with chloramine-T (29) and $\mathrm{AgNO}_{3}$ provided the C-H amination product (Scheme 1.49). 3) The aziridination did not proceed with the retention of the stereochemistry of the starting alkenes (Table 1.7). 


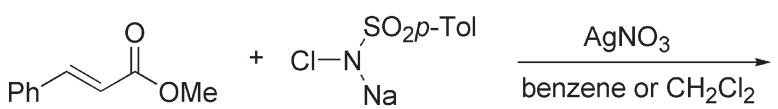

Scheme 1.48

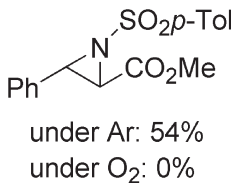<smiles>[N]N(Cl)S(=O)(=O)O[Na]</smiles>

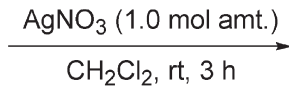<smiles>O=S(=O)(O)NC1COCCO1</smiles>

$34 \%$

Scheme 1.49

Table 1.8 Bromine-catalyzed aziridination of alkenes with chloramine-T (29).

alkenes
$(3.0 \mathrm{mmol})$

Bromine (ammonium tribromide) and iodine efficiently catalyze the aziridination of alkenes with chloramine-T (29). Sharpless found that catalytic use of phenyltrimethylammonium tribromide $\left(\mathrm{PhNMe}_{3}{ }^{+} \mathrm{Br}_{3}{ }^{-}, \mathrm{PTAB}\right)$ with chloramine-T (29) provides good to excellent yields of aziridines from various alkenes (Table 1.8) [58]. This simple operation can be applied in large-scale syntheses (up to $0.5 \mathrm{~mol}$ scales). Pyridinium hydrobromide perbromide $\left(\mathrm{Py} \cdot \mathrm{HBr}_{3}\right)$ has also been employed instead of PTAB for the chloramine-T-mediated aziridination [59].

The mechanism proposed for this bromine-catalyzed aziridination is shown in Scheme 1.50, with cis- $\beta$-methylstyrene I as a specific alkene. Initially the styrene reacts with a $\mathrm{Br}^{+}$source to give the bromonium cation II, and nucleophilic attack by $\mathrm{TsN}^{-} \mathrm{Cl}$ then affords a bromoaminated intermediate III. Attack either of $\mathrm{Br}^{-}$or of $\mathrm{TsN}^{-} \mathrm{Cl}$ on the $\mathrm{N}-\mathrm{Cl}$ group in III gives sulfonamide anion IV, which cyclizes intramolecularly to afford aziridine $\mathrm{V}$. The regenerated $\mathrm{Br}-\mathrm{X}$ initiates another catalytic cycle. 


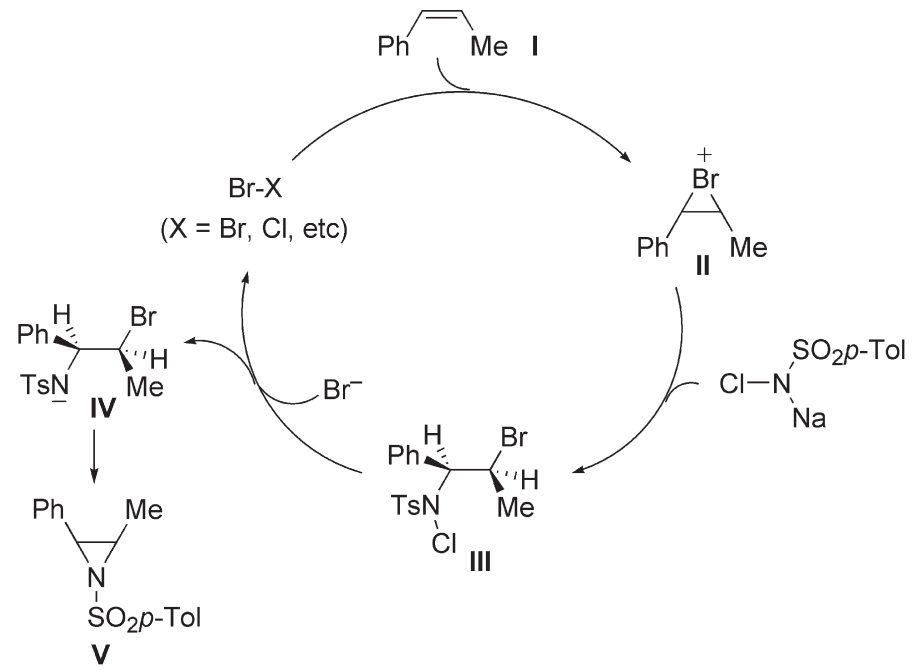

Scheme 1.50 Catalytic cycle of bromine-catalyzed aziridination.

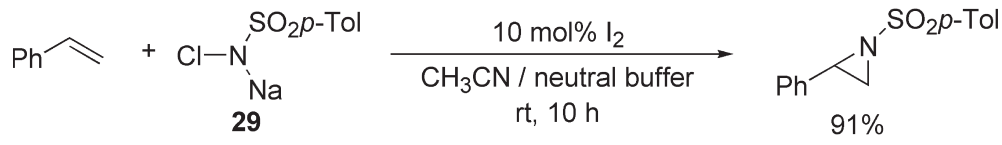

Scheme 1.51

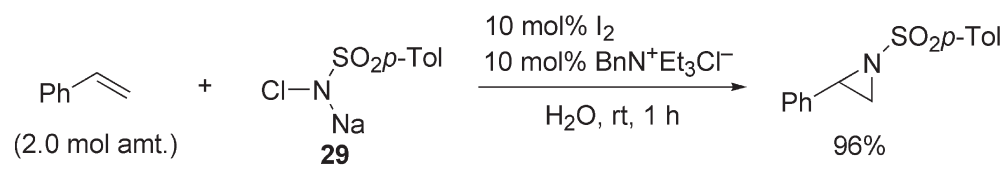

\section{Scheme 1.52}

Komatsu reported an iodine-catalyzed aziridination of alkenes (Scheme 1.51) [60]. When 2 molar amounts of styrene are added to chloramine-T (29) in the presence of a catalytic amount of iodine in a 1:1 mixture of $\mathrm{CH}_{3} \mathrm{CN}$ and a neutral buffer, for example, the corresponding aziridine is obtained in $91 \%$ yield. A similar reaction mechanism based on the above bromine-catalyzed aziridination is proposed.

This chloramine-T/iodine system has been applied to an organic solvent-free aziridination of alkenes in combination with a phase-transfer catalyst (Scheme 1.52) [61]. No reaction is observed when alkenes are treated with chloramine-T (29) and a catalytic amount of iodine in water, while the addition of a catalytic amount of benzyltriethylammonium chloride (BTEAC) results in a dramatic acceleration of the reaction, to yield aziridines in good yield. The silica gel/water combination as the reaction medium was also found to be effective for the iodinecatalyzed aziridination with chloramine-T (29) [62]. 


\subsection{4}

\section{Other Applications}

Chloramine-T (29) can be used as a nitrogen source in the synthesis of azaheterocycles. A chloramine- $\mathrm{T} / \mathrm{AgNO}_{3}$ system, which is believed to generate a nitrogen radical species (a triplet nitrene), has been applied to the synthesis not only of aziridines from monoenes (Section 1.6.3), but also of bicyclic pyrrolidines from 1,6-dienes (Scheme 1.53) [57]. The bicyclic pyrrolidine derivatives were obtained by tandem radical cyclization. The formation of trans-substituted cyclopentane derivatives as by-products would be one piece of evidence of the formation of biradical intermediate $\mathrm{A}$.
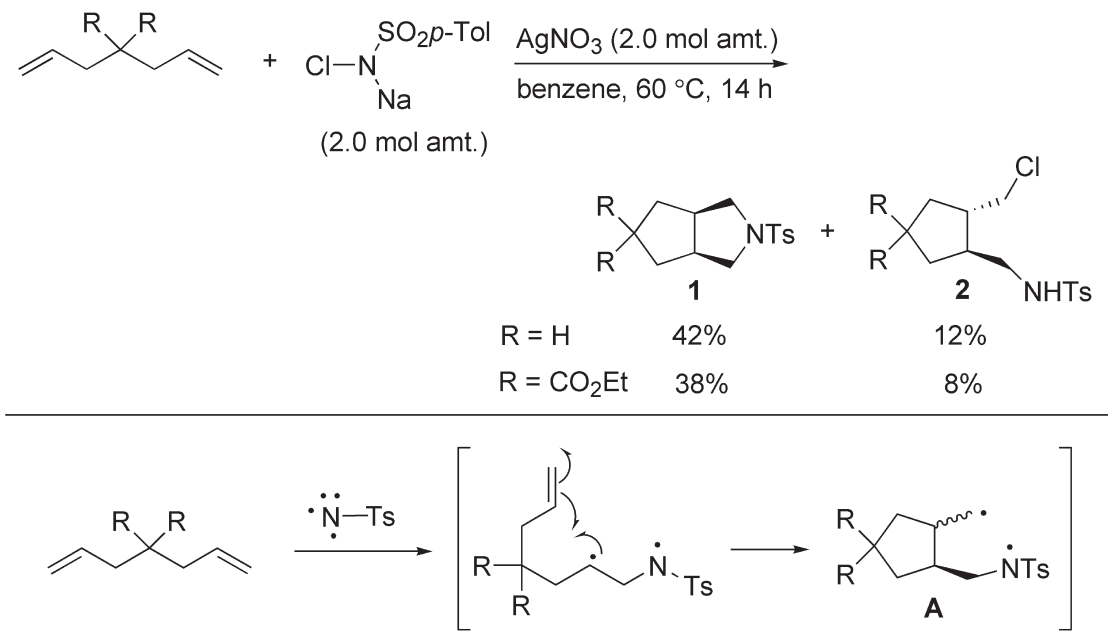

$\longrightarrow 1$ or 2

Scheme 1.53 Synthesis of bicyclic pyrrolidines from 1,6-dienes by use of the $\mathrm{AgNO}_{3} /$ chloramine-T system.

2-Iodomethyl pyrrolidine derivatives have been synthesized from $\gamma$-iodo alkenes with chloramine-T (29; Table 1.9) [63]. The cyclization proceeds with high stereoselectivity, via a cyclic iodonium intermediate. The iodo group in the substrate plays multiple roles, as: (1) a leaving group for the substitution with chloramine-T, (2) a Lewis base for the abstraction of the $\mathrm{Cl}$ atom, (3) an activator of the alkenyl moiety, and (4) a functional group in the product (Scheme 1.54).

Recently, Minaleata and Komatsu have reported a new type of aminochlorination of various alkenes by use of chloramine-T (29) and $\mathrm{CO}_{2}$ [64]. When styrene was treated with chloramine-T under $\mathrm{CO}_{2}(10 \mathrm{~atm})$ at $70^{\circ} \mathrm{C}$, aminochlorination occurred regioselectively to afford the $\beta$-chloro amine in $80 \%$ yield (Scheme 1.55 ). In the aminochlorination of a diene such as cycloocta-1,3-diene under the same conditions, a 1,4-adduct is formed as the sole product in $70 \%$ yield without the formation of any 1,2-adduct (Scheme 1.56). 
Table 1.9 Synthesis of 2-iodomethyl pyrrolidine derivatives from $\gamma$-iodo alkenes with chloramine-T (29).
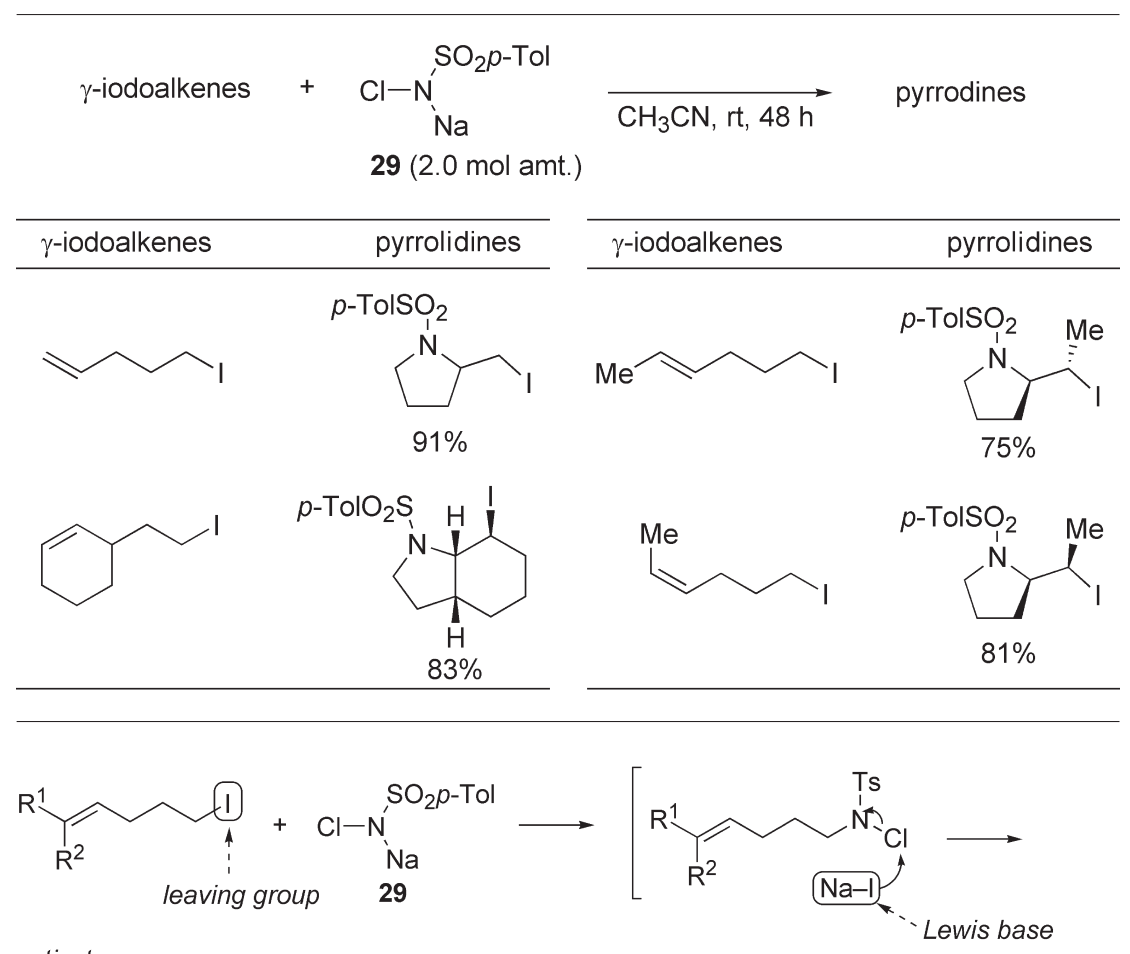

activator

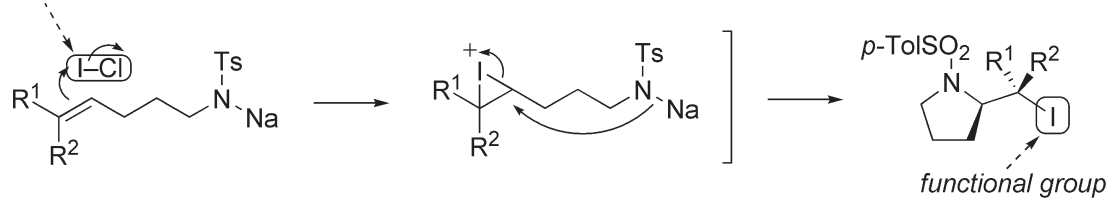

Scheme 1.54 Proposed mechanism of the stereoselective formation of 2-iodomethyl pyrrolidine derivatives.

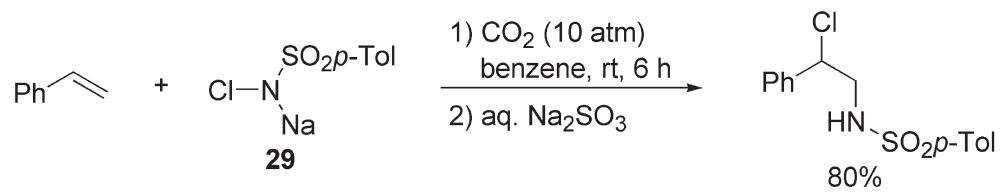

Scheme 1.55

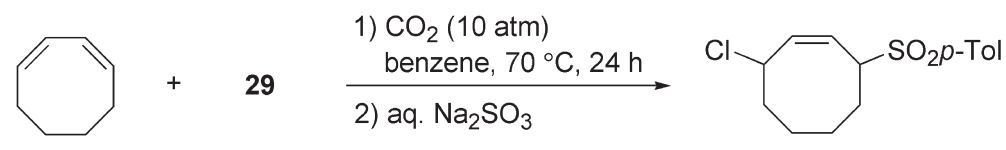

$70 \%$ (single isomer)

\section{Scheme 1.56}




\subsection{5}

\section{Experimental Procedures}

Asymmetric oxyamination of an alkene with an $\mathrm{N}$-halocarbamate salt A freshly prepared water $(7.5 \mathrm{~mL})$ solution of $\mathrm{NaOH}(0.122 \mathrm{~g}, 3.05 \mathrm{mmol})$ was added to a solution of benzyl carbamate $(0.469 \mathrm{~g}, 3.10 \mathrm{mmol})$ in $n$-PrOH $(4 \mathrm{~mL})$, followed by a freshly prepared solution of $t-\mathrm{BuOCl}(0.331 \mathrm{~g}, 3.05 \mathrm{mmol})$. Next, a solution of the ligand (DHQ) $)_{2}$ PHAL $(40 \mathrm{mg}, 0.05 \mathrm{mmol})$ in $n$-PrOH $(3.5 \mathrm{~mL})$ was added. After the mixture had been stirred for a few minutes, methyl trans-cinnamate $(0.162 \mathrm{~g}$, $1 \mathrm{mmol})$ and $\mathrm{K}_{2} \mathrm{OsO}_{2}(\mathrm{OH})_{4}(14.7 \mathrm{mg}, 0.04 \mathrm{mmol})$ were added. The mixture was stirred for $40 \mathrm{~min}$ at room temperature, and the light green color of the solution had changed to light yellow at the end. Ethyl acetate $(7 \mathrm{~mL})$ was added to the mixture and the aqueous phase was extracted with ethyl acetate $(5 \mathrm{~mL} \times 3)$. The combined extracts were washed with water and brine and dried over $\mathrm{MgSO}_{4}$. Volatile materials were concentrated in vacuo to afford the crude mixture, which was purified by flash column chromatography (hexane/chloroform/methanol 6:4:1 $v / v / v)$ to provide the desired compound $(0.204 \mathrm{~g}, 65 \%, 94 \%$ ee) as a colorless solid.

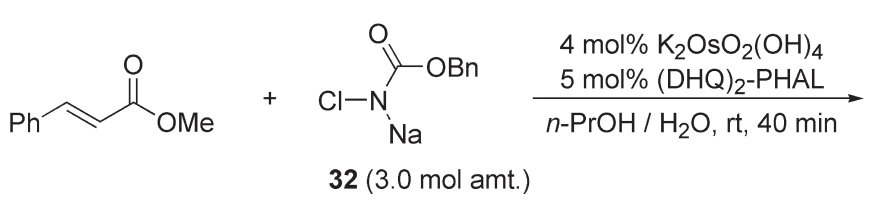<smiles>COC(=O)[C@H](O)[C@H](NC(=O)OCc1ccccc1)c1ccccc1</smiles>

$65 \%, 94 \%$ ee

Copper(I)-catalyzed aziridination of alkenes Anhydrous chloramine-T (29, $114 \mathrm{mg}$, $0.50 \mathrm{mmol})$ and $\mathrm{MS}(5 \AA, 50 \mathrm{mg})$ were added to a solution of $\mathrm{CuCl}(2.5 \mathrm{mg}$, $0.25 \mathrm{mmol}$ ) and trans- $\beta$-methylstyrene $(295 \mathrm{mg}, 2.5 \mathrm{mmol})$ in acetonitrile $(5 \mathrm{~mL})$. The reaction mixture was stirred at $25^{\circ} \mathrm{C}$ for $3 \mathrm{~h}$ under nitrogen and the reaction mixture was then passed through a $3 \mathrm{~cm}$ plug of silica gel with elution with $\mathrm{CH}_{2} \mathrm{Cl}_{2}$. The solvent was removed in vacuo to give a crude oil, which was purified by flash column chromatography to give trans-2-methyl-3-phenyl-1-tosylaziridine ( $92 \mathrm{mg}$, $0.32 \mathrm{mmol}$ ) in $64 \%$ yield.

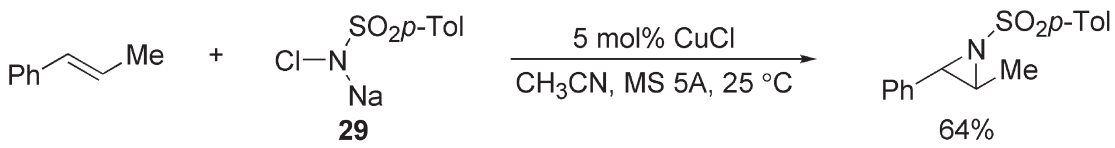

Bromine-catalyzed aziridination of alkenes Trimethylphenylammonium tribromide $\left(113 \mathrm{mg}, 0.3 \mathrm{mmol}\right.$ ) was added at $25^{\circ} \mathrm{C}$ to a mixture of trans-hex-3-ene (252 mg, $3 \mathrm{mmol}$ ) and anhydrous chloramine-T (29, $751 \mathrm{mg}, 3.3 \mathrm{mmol})$ in $\mathrm{CH}_{3} \mathrm{CN}$ $(15 \mathrm{~mL})$. After vigorous stirring for $12 \mathrm{~h}$, the reaction mixture was concentrated (to about $1 / 10$ volume) and filtered through a short column of silica gel (10\% EtOAc in hexane). After evaporation of the solvent, the resultant solid was purified by 
crystallization from hexane to give trans-2,3-diethyl-1-[(4-methylphenyl)sulfonyl]a ziridine $(710 \mathrm{mg}, 2.8 \mathrm{mmol})$ in $93 \%$ yield as colorless crystals.

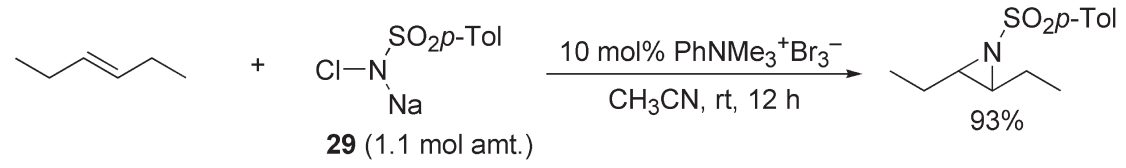

Synthesis of iodomethylated pyrrolidine derivatives 5-Iodopent-1-ene (196 mg, $1.0 \mathrm{mmol})$ was added to a suspension of chloramine-T $(29,455 \mathrm{mg}, 2.0 \mathrm{mmol})$ in $\mathrm{CH}_{3} \mathrm{CN}(6.0 \mathrm{~mL})$. The mixture was stirred under nitrogen in the dark at room temperature for $48 \mathrm{~h}$. After the addition of $\mathrm{Et}_{2} \mathrm{O}(40 \mathrm{~mL})$, the organic layer was washed with $\mathrm{H}_{2} \mathrm{O}(60 \mathrm{~mL})$, the aqueous phase was extracted with $\mathrm{Et}_{2} \mathrm{O}(2 \times 20 \mathrm{~mL})$, and the combined extracts were washed with brine $(30 \mathrm{~mL})$, dried over $\mathrm{K}_{2} \mathrm{CO}_{3}$, and concentrated in vacuo. The resulting crude materials were purified by flash column chromatography (silica gel, 10\% EtOAc in hexane) to give 2-iodomethyl-1-( $p$-tolyls ulfonyl)pyrrolidine (332 mg, $0.91 \mathrm{mmol}$ ) in $91 \%$ yield.
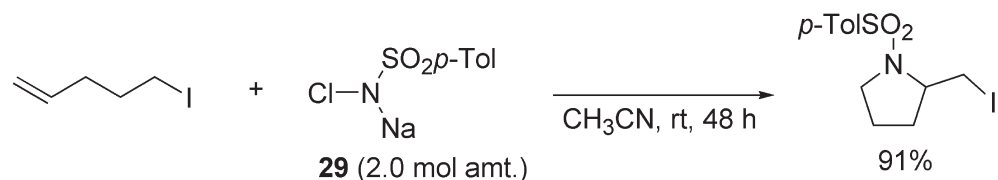

$\mathrm{CO}_{2}$-promoted aminochlorination of alkenes Chloramine- $\mathrm{T}(281 \mathrm{mg}, 1 \mathrm{mmol})$, styrene $(104 \mathrm{mg}, 1 \mathrm{mmol})$, and benzene $(3 \mathrm{~mL})$ were placed in a $50 \mathrm{~mL}$ stainless steel autoclave lined with a glass liner. The autoclave was closed, purged three times with carbon dioxide, pressurized with $\mathrm{CO}_{2}(10 \mathrm{~atm})$, and then stirred at room temperature for $6 \mathrm{~h}$. After discharging of excess $\mathrm{CO}_{2}$, aqueous $\mathrm{Na}_{2} \mathrm{~S}_{2} \mathrm{O}_{3}(0.5 \mathrm{M}$, $20 \mathrm{~mL}$ ) was added to the reaction mixture, the organic materials were extracted with $\mathrm{CH}_{2} \mathrm{Cl}_{2}(10 \mathrm{~mL} \times 3)$, and the combined extracts were dried over $\mathrm{Na}_{2} \mathrm{SO}_{4}$ and concentrated to give the crude products. Purification by flash column chromatography (silica gel, 30\% EtOAc in hexane) gave 1-chloro-1-phenyl-2-[(4-methylphenyl) sulfonamido]ethane $(247 \mathrm{mg}, 0.797 \mathrm{mmol})$ in $80 \%$ yield.<smiles>[N]N(Cl)S(=O)(=O)O</smiles>

29

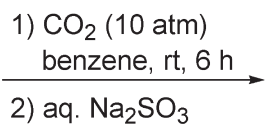

2) aq. $\mathrm{Na}_{2} \mathrm{SO}_{3}$<smiles>O=S(=O)(NCC(Cl)c1ccccc1)O[Na]</smiles>
$80 \%$

\section{7}

\section{N-Sulfonyliminophenyliodinane}

$\mathrm{N}$-Sulfonyliminophenyliodinane [65] derivatives are employed for the generation of transition metal-nitrene complexes, which are then applied to the catalytic 
amination of saturated $\mathrm{C}-\mathrm{H}$ bonds and alkenes. Since amination of saturated $\mathrm{C}-\mathrm{H}$ bonds is summarized elsewhere in this book (Chapter 2), only the transition metal-catalyzed amination of various alkenes is introduced in this section.

\subsection{1}

\section{Transition Metal-Catalyzed Amination of Alkenes}

Various transition metals such as Fe [66], Mn [66], Ru [67], Rh [68], $\mathrm{Cu}$ [69], and $\mathrm{Ag}$ [70] have been used for aziridination of alkenes with $N$-p-tolylsulfonyliminophenyliodinane (33) (Scheme 1.57). Treatment with silyl enol ethers affords $\alpha$ amino ketones through hydrolysis of the resulting 2-siloxy-1-sulfonylaziridines (Scheme 1.58).

Recently, efficient aziridination reactions of alkenes have been reported to occur on combined use of $\mathrm{AgNO}_{3}$ and a tridentate ligand, 4,4',4"-tri-tert-butyl-2,2':6',2"terpyridine ( $t$-Bu $\mathrm{Bu}_{3}$ tpy) (Table 1.10) [70]. A unique disilver(I) complex is assumed to be the reactive intermediate; its structure has been verified by single-crystal X-ray structural analysis (Scheme 1.59).

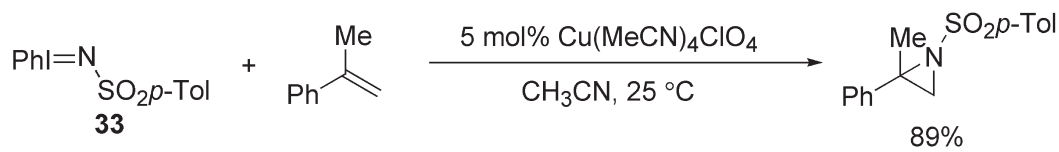

\section{Scheme 1.57}

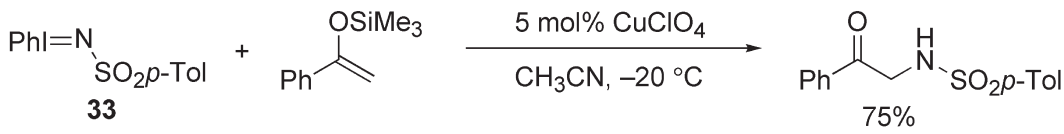

Scheme 1.58

Table 1.10 Ag(I)-catalyzed aziridination of alkenes with $\mathrm{N}$-sulfonyliminophenyliodinane (33).

alkenes $+{ }_{\text {alkenes }}{ }_{\text {aziridines (yield } / \%)}$ alkenes



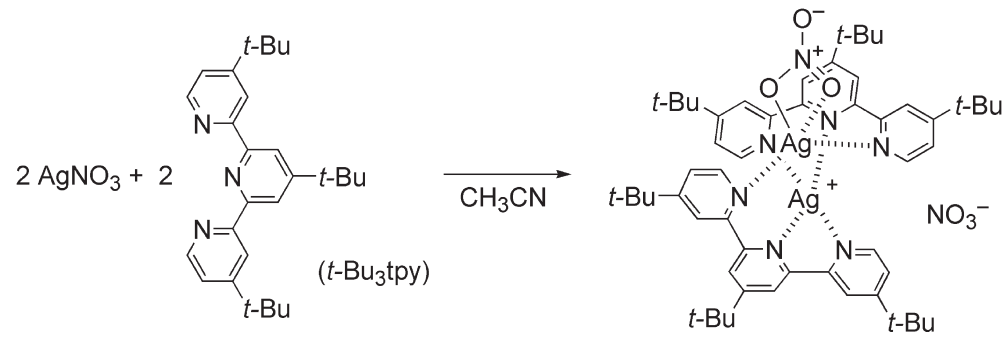

\section{Scheme 1.59}

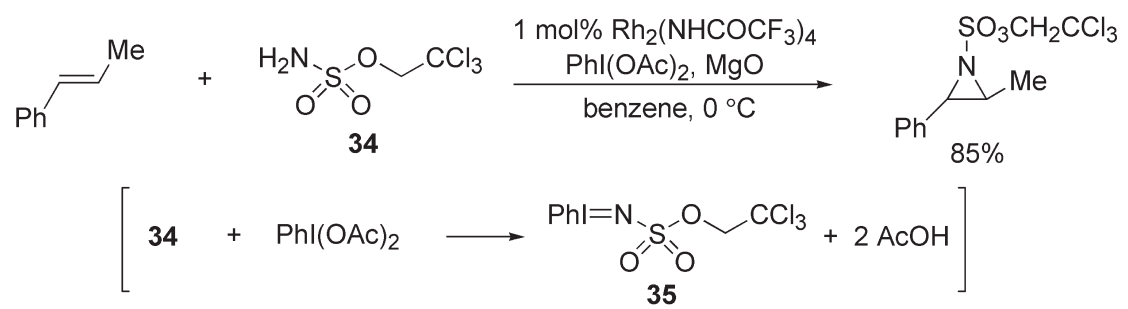

Scheme 1.60 Rh-catalyzed aziridination of alkenes by the use of sulfamate ester 34 and $\mathrm{Phl}(\mathrm{OAc})_{2}$.

Many catalytic asymmetric aziridinations of alkenes with 33 in the presence of metal complexes with chiral bis(oxazoline), salen, and porphyrin ligands have been reported [71].

$\mathrm{Du}$ Bois developed Rh(II)-catalyzed aziridination of alkenes by the combined use of trichloroethylsulfamate ester 34 and $\mathrm{PhI}(\mathrm{OAc})_{2}$ in the presence of $\mathrm{MgO}$ [72], in which $N$-trichloroethylsulfonyliminophenyliodinane (35) is generated in situ as a nitrogen source (Scheme 1.60). Au(I) complexes also catalyze the same type of aziridination of alkenes [73].

\section{7 .2}

\section{Experimental Procedures}

Representative procedure for $\mathrm{Ag}(\mathrm{I})$-catalyzed aziridination of alkenes A mixture of

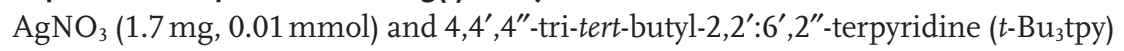
(4.0 mg, $0.01 \mathrm{mmol}$ ) was stirred in $\mathrm{CH}_{3} \mathrm{CN}(2 \mathrm{~mL})$ for $5-10 \mathrm{~min}$. $N$-p-Tolylsulfonyliminophenyliodinane $(33,86.5 \mathrm{mg}, 0.5 \mathrm{mmol})$, together with MS (4 $\mathrm{A}, 0.5 \mathrm{~g})$, was added to the mixture. Hex-1-ene $(210 \mathrm{mg}, 2.5 \mathrm{mmol})$ was added and the solution was stirred at $0^{\circ} \mathrm{C}$ for $0.5 \mathrm{~h}$, and further stirred at room temperature for $20 \mathrm{~h}$. The reaction mixture was diluted with $\mathrm{CH}_{2} \mathrm{Cl}_{2}(10 \mathrm{~mL})$ and filtered through a Celite pad. The filter cake was washed with $\mathrm{CH}_{2} \mathrm{Cl}_{2}(2 \times 5 \mathrm{~mL})$ and the combined extracts were concentrated under reduced pressure. The resulting crude mixture was 
purified by flash column chromatography (silica gel, hexane/EtOAc $4: 1$ ) to give the desired aziridine $(89.9 \mathrm{mg}, 0.36 \mathrm{mmol})$ in $71 \%$ yield.<smiles>C=CCCCC</smiles>

33<smiles>CCCCC1CN1S(=O)(=O)O[Na]</smiles>

Representative procedure for $\mathrm{Rh}$ (II)-catalyzed aziridination of alkenes by combined use of trichloroethylsulfamate ester 34 and $\mathrm{PhI}(\mathrm{OAc})_{2}$

trans- $\beta$-Methylstyrene $(59 \mathrm{mg}, \quad 0.50 \mathrm{mmol}), \mathrm{MgO} \quad(46 \mathrm{mg}, 1.15 \mathrm{mmol})$, and $\mathrm{Rh}_{2}\left(\mathrm{NHCOCF}_{3}\right)_{4}(3 \mathrm{mg}, 5.0 \mathrm{mmol})$ were added sequentially to a solution of trichloroethylsulfamate ester $34(126 \mathrm{mg}, 0.55 \mathrm{mmol})$ in benzene. The resulting purple mixture was cooled to $0^{\circ} \mathrm{C}$ and $\mathrm{PhI}(\mathrm{OAc})_{2}(209 \mathrm{mg}, 0.65 \mathrm{mmol})$ was added. The suspension quickly turned orange after the addition of $\mathrm{PhI}(\mathrm{OAc})_{2}$ and was allowed to warm slowly to $25^{\circ} \mathrm{C}$ over $2 \mathrm{~h}$. After $6 \mathrm{~h}$, the reaction mixture was diluted with $\mathrm{CH}_{2} \mathrm{Cl}_{2}(10 \mathrm{~mL})$ and filtered through a Celite pad. The filter cake was washed with $\mathrm{CH}_{2} \mathrm{Cl}_{2}$, the combined extracts were concentrated under reduced pressure, and the resulting crude materials were purified by flash column chromatography (silica gel hexane/EtOAc 9:1) to give trans-2-methyl-3-phenyl-1-trichloroethylsulfonyl aziridine (140 mg, $0.43 \mathrm{mmol}$ ) in $85 \%$ yield.<smiles>C/C=C/c1ccccc1</smiles>

\section{8}

\section{Transition Metal-Nitride Complexes}

There are many reports on the generation and the characterization of transition metal/nitrido complexes [74], some of which have been applied to stoichiometric nitrogen atom transfer reactions to organic molecules.

\subsection{1}

\section{Nitrogen Atom Transfer Mediated by Transition Metal-Nitride Complexes}

Carreira developed new methods to prepare manganese Schiff base-nitrido complexes 35, which were used in the amination of alkenes including silyl enol ethers and glycals [75]. The $\mathrm{Mn}(\mathrm{V})$-nitrido complex of $\mathrm{H}_{2}$ saltmen [saltmen = (1,1,2,2-tetr amethylethylene)bis(salicylideneaminato)] 35 is prepared by the following two step-procedure at scales of up to $20 \mathrm{~g}$ as explained in the Experimental section (Scheme 1.61). 


\author{
1) $\mathrm{Mn}(\mathrm{OAc})_{2} \cdot 4 \mathrm{H}_{2} \mathrm{O}$ \\ $\mathrm{H}_{2}$ saltmen 2) $\mathrm{NH}_{4} \mathrm{OH} /$ aq. $\mathrm{NaOCl}$
}

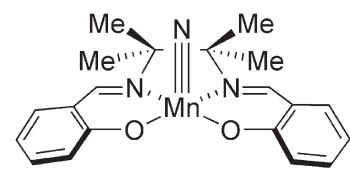

(saltmen) $\mathrm{Mn}(\mathrm{N}) 35$

\section{Scheme 1.61}<smiles>C=C(OC)c1ccccc1</smiles>

Scheme 1.62

$$
\begin{gathered}
\stackrel{\text { (saltmen }) \mathrm{Mn}(\mathrm{N}) 35}{\left(\mathrm{CF}_{3} \mathrm{CO}\right)_{2} \mathrm{O}, \text { pyridine }} \\
\underset{\mathrm{CH}_{2} \mathrm{Cl}_{2},-30 \text { to }-23^{\circ} \mathrm{C}}{\longrightarrow}
\end{gathered}
$$

1) (saltmen) $\mathrm{Mn}(\mathrm{N}) 35$

$$
\text { 2) silica gel or } \mathrm{H}_{3} \mathrm{O}^{+}
$$<smiles>O=C(CNC(=O)C(F)(F)F)c1ccccc1</smiles>

$69 \%$<smiles>O[C@@H]1C=CO[C@@H]2CO[C@@H](P)O[C@H]12</smiles>

Scheme 1.63<smiles>O=C(N[C@@H]1[C@H](O)[C@H]2O[C@@H](c3ccccc3)OC[C@H]2O[C@H]1O)C(F)(F)F</smiles>

Treatment of a solution of nitrido complex 35, silyl enol ether, and pyridine in $\mathrm{CH}_{2} \mathrm{Cl}_{2}$ with trifluoroacetic anhydride at $-30^{\circ} \mathrm{C}$ provides $\mathrm{N}$-trifluoroacetyl $\alpha$-amino ketone (Scheme 1.62). This reaction may proceed through the initial formation of a reactive $N$-trifluoroacetylimidomanganese species, with the subsequent transfer of $\mathrm{CF}_{3} \mathrm{CON}$ group to an alkene.

By this procedure the stereoselective synthesis of 2-aminosaccharides has been performed starting from glycals (Scheme 1.63).

Recently, nitrido ruthenium porphyrin complexes have been found to effect amination of silyl enol ethers or hydrocarbons [76].

Development of chiral nitridomanganese complexes such as 36 and their use for asymmetric preparation of aziridines and oxazolines have been reported by Komatsu [77]. The complex 36 reacts with alkenes in the presence of $p$ toluenesulfonic anhydride or some sulfonyl chlorides to give optically active $\mathrm{N}$ sulfonylaziridines (Scheme 1.64). When acid chlorides are used instead of sulfonyl chlorides, oxazolines are formed, presumably via $\mathrm{N}$-acylaziridines as intermediates (Scheme 1.65).

\section{8 .2}

\section{Experimental Procedures}

Preparation of $\mathbf{H}_{2}$ saltmen $\mathrm{Mn}(\mathrm{V}) /$ nitrido complex $\mathrm{H}_{2}$ saltmen [saltmen $=(1,1,2,2$ tetramethylethylene)bis(salicylideneaminato)] (10.0 g, $30.8 \mathrm{mmol})$ was suspended 


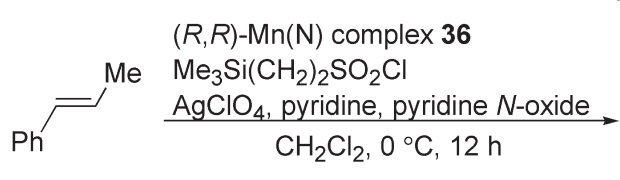

Scheme 1.64

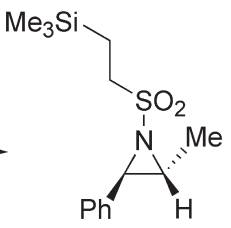

$70 \%, 83 \%$ ee

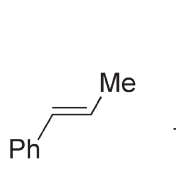

$(R, R)-\mathrm{Mn}(\mathrm{N})$ complex 36
$\mathrm{PhCOCl}, \mathrm{AgBF}_{4}$
pyridine $\mathrm{N}$-oxide
$\mathrm{CH}_{2} \mathrm{Cl}_{2}, 0^{\circ} \mathrm{C}, 48 \mathrm{~h}$
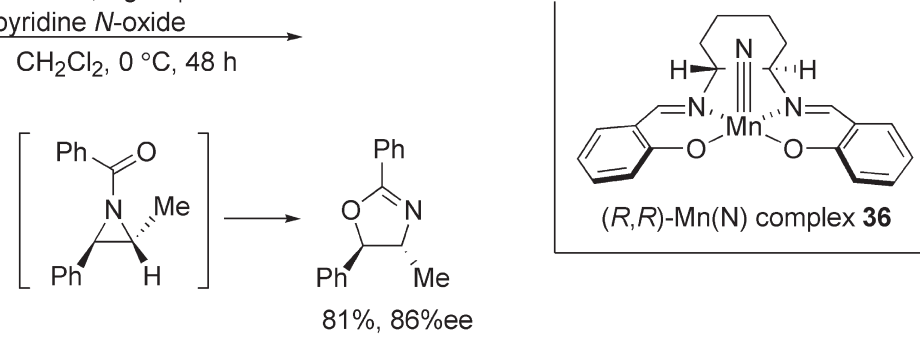

Scheme 1.65

in $\mathrm{MeOH}(400 \mathrm{~mL})$ and the mixture was heated at $50-60^{\circ} \mathrm{C} . \mathrm{Mn}(\mathrm{OAc})_{2} \cdot 4 \mathrm{H}_{2} \mathrm{O}$ $(7.90 \mathrm{~g}, 32.4 \mathrm{mmol})$ was added portionwise to the yellow solution. The resulting dark brown solution was heated at reflux for $1 \mathrm{~h}$ and at $23^{\circ} \mathrm{C}$ for $0.5 \mathrm{~h}$. Conc. $\mathrm{NH}_{4} \mathrm{OH}(15 \mathrm{M}, 31.0 \mathrm{~mL}, 465 \mathrm{mmol})$ was then added dropwise over $5 \mathrm{~min}$, after which aqueous $\mathrm{NaOCl}(0.7 \mathrm{M}, 280 \mathrm{~mL}, 196 \mathrm{mmol})$ was added to the vigorously stirred mixture over $40 \mathrm{~min}$. When the addition was complete, the mixture was cooled to $0^{\circ} \mathrm{C}$ and diluted with $\mathrm{CH}_{2} \mathrm{Cl}_{2}(400 \mathrm{~mL})$, and the resulting biphasic mixture was warmed to $23^{\circ} \mathrm{C}$ and stirred for $15 \mathrm{~min}$. The contents were transferred to a separating funnel with $\mathrm{H}_{2} \mathrm{O}(200 \mathrm{~mL})$, the organic phase was isolated, and the aqueous layer was extracted with $\mathrm{CH}_{2} \mathrm{Cl}_{2}(200 \mathrm{~mL})$. The combined extracts were washed with $\mathrm{H}_{2} \mathrm{O}(6 \times 300 \mathrm{~mL})$ and concentrated in vacuo to afford $12 \mathrm{~g}$ of a dark green solid. The solid materials were dissolved in $\mathrm{CH}_{2} \mathrm{Cl}_{2}(50-75 \mathrm{~mL})$ and filtered through a $70 \times 200 \mathrm{~mm}$ plug of Brockmann activity-IV basic $\mathrm{Al}_{2} \mathrm{O}_{3}$ with $\mathrm{CH}_{2} \mathrm{Cl}_{2}$ as the eluent. A dark green band was collected as a single fraction and the solvent was removed in vacuo. The resulting green solid was suspended in EtOAc at reflux $(150 \mathrm{~mL})$, to which hexane $(300 \mathrm{~mL})$ was added. The contents were cooled to $23^{\circ} \mathrm{C}$ and then placed in a freezer at $-20^{\circ} \mathrm{C}$ for $10 \mathrm{~h}$. The dark green microcrystalline precipitate was collected and rinsed with an ice cold hexane/EtOAc mixture $(2: 1$, $3 \times 50 \mathrm{~mL})$. The product $35(10.2 \mathrm{~g}, 85 \%)$ was dried under vacuum at 1 Torr for $5 \mathrm{~h}$.

\footnotetext{
1) $\mathrm{Mn}(\mathrm{OAc})_{2} \cdot 4 \mathrm{H}_{2} \mathrm{O}$

$\mathrm{H}_{2}$ saltmen 2) $\mathrm{NH}_{4} \mathrm{OH} /$ aq. $\mathrm{NaOCl}$
}

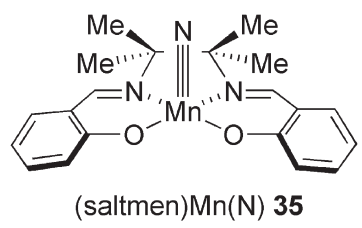


Representative procedure for the stereoselective synthesis of 2-aminosaccharides mediated by the $\mathrm{Mn}(\mathrm{V}) /$ nitrido complex Trifluoroacetic anhydride $(200 \mu \mathrm{L}$, $1.4 \mathrm{mmol}$ ) was added to a solution of glycal $(139 \mathrm{mg}, 0.40 \mathrm{mmol})$ in $\mathrm{CH}_{2} \mathrm{Cl}_{2}(0.5 \mathrm{~mL})$, and a solution of (saltmen) $\mathrm{Mn}(\mathrm{N}) 35$ in $\mathrm{CH}_{2} \mathrm{Cl}_{2}(0.4 \mathrm{M}, 10 \mathrm{~mL}, 0.4 \mathrm{mmol})$ was slowly added by syringe pump over $7 \mathrm{~h}$. After the addition of (saltmen) $\mathrm{Mn}(\mathrm{N})$, silica gel $(500 \mathrm{mg})$ and Celite $(500 \mathrm{mg})$ were added to the resultant dark brown solution, together with pentane $(15 \mathrm{~mL})$. The dark brown slurry was stirred vigorously for $30 \mathrm{~min}$ before being filtered through a $20 \times 50 \mathrm{~mm}$ plug of silica gel with $\mathrm{Et}_{2} \mathrm{O}(2$ $\times 10 \mathrm{~mL}$ ) as an eluent. Concentration of the filtrate under vacuum afforded a pale yellow residue, which was purified by flash column chromatography (silica gel) to give the desired 2-amino sugar ( $143 \mathrm{mg}, 0.30 \mathrm{mmol}$ ) in $75 \%$ yield.<smiles>O[C@H]1C=CO[C@@H]2COC(c3ccccc3)O[C@H]12</smiles>

1) (saltmen) $\mathrm{Mn}(\mathrm{N}) 35$

$$
\text { 2) silica gel or } \mathrm{H}_{3} \mathrm{O}^{+}
$$<smiles>O=C(N[C@@H]1[C@H](O)[C@@H]2O[C@H](c3ccccc3)OC[C@H]2O[C@H]1O)C(F)(F)F</smiles>

$75 \%$

Representative procedure for the asymmetric synthesis of 2-oxazolines from alkenes with the aid of chiral nitridomanganese complexes Pyridine $(12 \mathrm{mg}, 0.15 \mathrm{mmol})$, trans- $\beta$-methylstyrene ( $354 \mathrm{mg}, 3.0 \mathrm{mmol})$, and benzoyl chloride $(51 \mathrm{mg}, 0.36 \mathrm{mmol}$ ) were added at $0^{\circ} \mathrm{C}$ to a mixture of an $(R, R)-\mathrm{Mn}(\mathrm{N})$ complex $36(117 \mathrm{mg}, 0.3 \mathrm{mmol})$, $\mathrm{AgBF}_{4}\left(70 \mathrm{mg}, 0.36 \mathrm{mmol}\right.$ ), and pyridine $N$-oxide $(34 \mathrm{mg}, 0.36 \mathrm{mmol})$ in $\mathrm{CH}_{2} \mathrm{Cl}_{2}$ $(3 \mathrm{~mL})$. After the mixture had been stirred at $0{ }^{\circ} \mathrm{C}$ for $48 \mathrm{~h}$, pentane $(20 \mathrm{~mL})$ was added. The mixture was passed through a $3 \mathrm{~cm}$ pad of silica gel with $\mathrm{Et}_{2} \mathrm{O}(125 \mathrm{~mL})$ as the eluent. The filtrate was concentrated under vacuum, and the resulting residue was purified by flash column chromatography (silica gel, hexane/EtOAc) to afford $(4 R, 5 R)$-4-methyl-2,5-diphenyl-2-oxazoline $(58 \mathrm{mg}, 0.24 \mathrm{mmol})$ in $81 \%$ yield. The enantiomeric excess of the oxazoline was determined by chiral HPLC analysis $(81 \%$ ee).
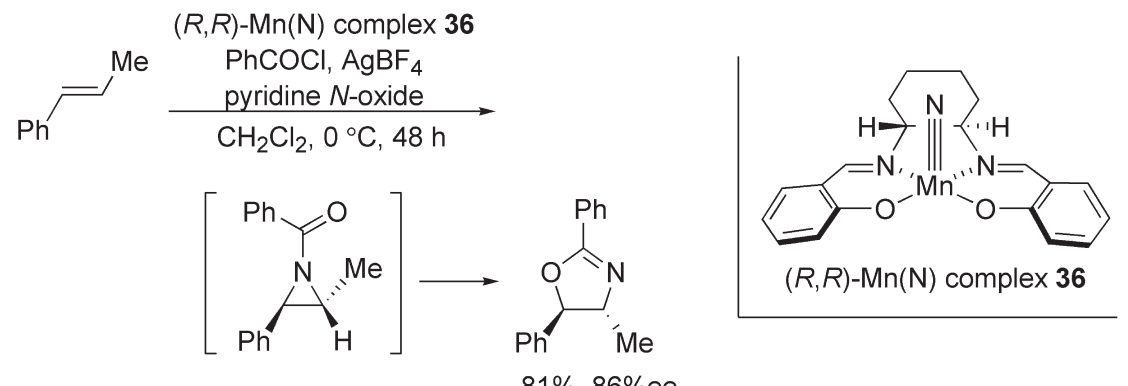

$81 \%, 86 \%$ ee

\section{9}

\section{Azido Derivatives}

Aliphatic azides are readily prepared by nucleophilic substitution of alkyl halides or sulfonates with sodium azide; the resulting alkyl azides are readily reduced to 
primary amines, while 1,3-dipolar cycloadditions of azide derivatives with dipolarophiles such as alkenes, alkynes, and nitriles [78] give various kinds of azaheterocyclic compounds. These transformations have been reported in detail in some recent reviews [79] and so are not discussed in this section.

\subsection{1}

\section{Electrophilic Amination of Organometallic Reagents with Organic Azides}

Some organic azido derivatives are utilized for the synthesis of primary amines through electrophilic amination of organometallic reagents.

Trost reported that phenylthiomethyl azide (37) can be used as a synthon for ${ }^{+} \mathrm{NH}_{2}$ by treatment with a Grignard reagent and subsequent hydrolysis of the resulting triazene (Scheme 1.66) [80]. This reagent can be applied to the preparation of a chiral secondary amine by treatment with a chiral Grignard reagent [22].

Allyl azide [81], trimethylsilylmethyl azide [82], or diphenylphosphoryl azide [83] are also used for the preparation of aromatic primary amines by treatment with aryl Grignard reagents.

For amination of enolates, Evans developed the electrophilic azidation of amide enolates with bulky 2,4,6-triisopropylbenzenesulfonyl azide 38 (Scheme 1.67) [84]. The resulting $\alpha$-azido carboxiimides can be converted into $\alpha$-amino acid derivatives.

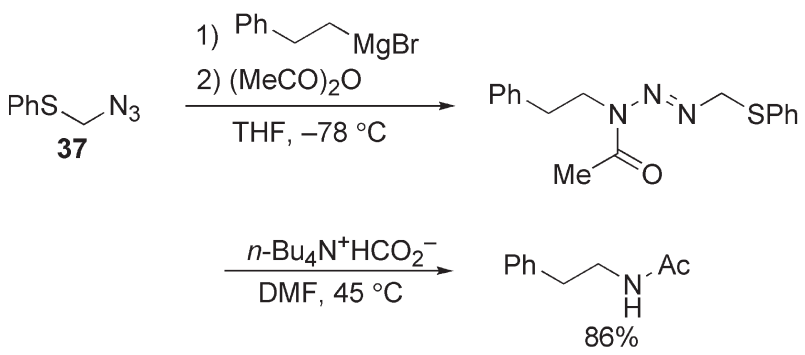

Scheme 1.66 Electrophilic amination of Grignard reagents with azide 37.

1) $\mathrm{KN}\left[\mathrm{Si}\left(\mathrm{NMe}_{2}\right)_{3}\right]$<smiles>O=C(CCc1ccccc1)N1C(=O)OC[C@H]1Cc1ccccc1</smiles>

Scheme 1.67 


\subsection{2}

\section{Radical-Mediated Amination with Sulfonyl Azides}

Organic azides have been investigated as radical traps for $\mathrm{C}-\mathrm{N}$ bond formation [85]. Sulfonyl azides are suitable for azidation of nucleophilic radicals such as secondary and tertiary alkyl radicals. Renaud developed ditin-mediated radical azidation with phenylsulfonyl azide (39) [86]. When a mixture of alkyl iodides (Scheme 1.68) or dithiocarbonates (Scheme 1.69) and phenylsulfonyl azide (39) is treated with hexabutylditin as a chain transfer reagent, the radical reaction is initiated by photoirradiation or thermal decomposition of di-tert-butylhyponitrite to give the corresponding alkyl azides.

This radical azidation is applied to domino $\mathrm{C}-\mathrm{C}$ bond formation-azidation sequences (Schemes 1.70 and 1.71) [87].

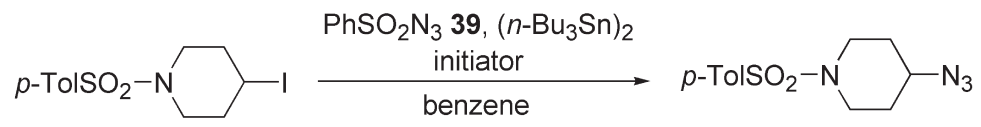

$$
\begin{array}{r}
\text { initiator method A: hv (a 300W sun lamp), rt } \quad 77 \% \\
\text { method B: cat. } t \text {-BuO-N=N-Ot-Bu, } 80^{\circ} \mathrm{C} \quad 89 \%
\end{array}
$$

\section{Scheme 1.68}

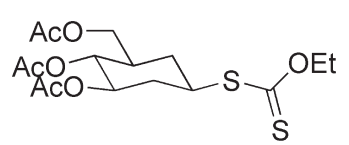

Scheme 1.69

$$
\begin{aligned}
& \mathrm{PhSO}_{2} \mathrm{~N}_{3} 39,\left(n-\mathrm{Bu}_{3} \mathrm{Sn}\right)_{2} \\
& \stackrel{\text { cat. } t-\mathrm{BuO}-\mathrm{N}=\mathrm{N}-\mathrm{O} t-\mathrm{Bu}}{\longrightarrow}
\end{aligned}
$$

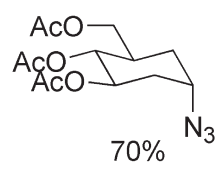<smiles>CC(C)=CCO[C@H]1OCCC[C@H]1I</smiles>

Scheme 1.70

\section{9 .3}

\section{Hydroazidation of Alkenes with Sulfonyl Azides}

Carreira developed the cobalt-catalyzed hydroazidation of alkenes with sulfonylazides, which allows the synthesis of secondary and tertiary alkyl azides [34d]. 

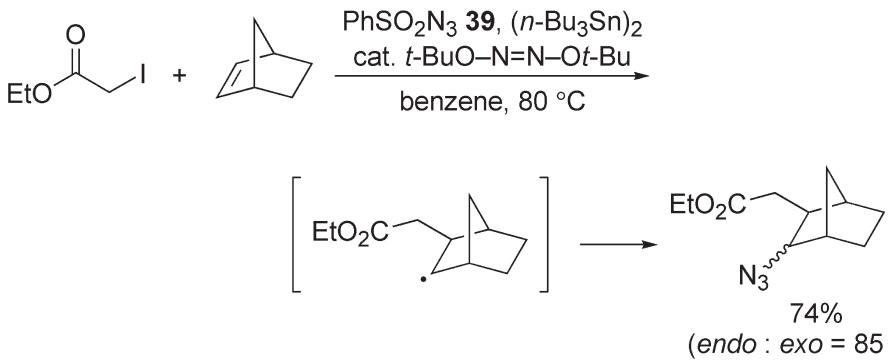

Scheme 1.71

Table 1.11 Co-catalyzed hydroazidation of alkenes with sulfonyl azide $\mathbf{4 0}$.

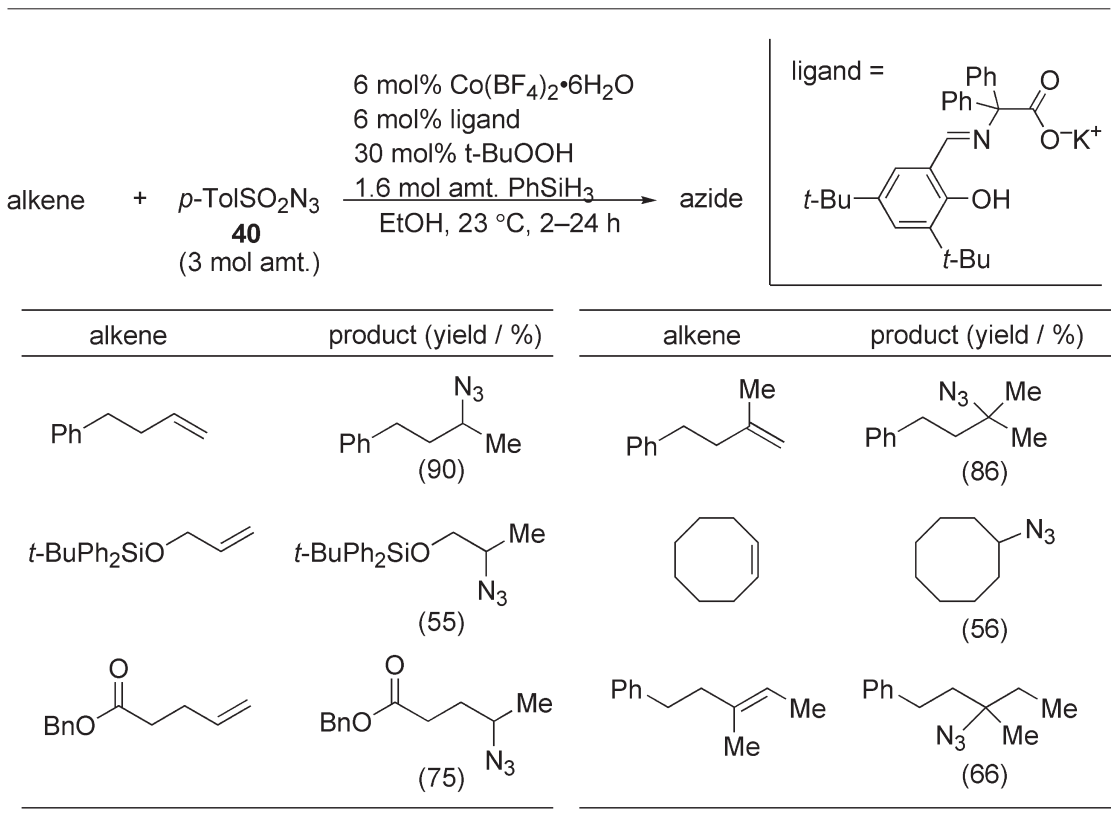

Treatment of mono-, di-, and trisubstituted alkenes with $p$-tolylsulfonyl azide (40) in the presence of phenylsilane and tert-butyl hydroperoxide $(30 \mathrm{~mol} \%)$ is catalyzed by $\mathrm{Co}\left(\mathrm{BF}_{4}\right)_{2} \cdot 6 \mathrm{H}_{2} \mathrm{O}$ and the Schiff base ligand to give alkyl azides in good yield (Table 1.11). The Markovnikov-type products are formed exclusively, with broad functional group tolerance.

\section{9 .4}

\section{Experimental Procedures}

Representative procedure for electrophilic azidation of amide enolates by utilization of 2,4,6-triisopropylbenzenesulfonyl azide A toluene solution of potassium 
hexamethyldisilazide (KHMDS, $0.48 \mathrm{M}, 2 \mathrm{~mL}, 0.960 \mathrm{mmol}$ ) was added at $-78^{\circ} \mathrm{C}$ to THF $(3 \mathrm{~mL})$. A precooled $\left(-78^{\circ} \mathrm{C}\right)$ solution of the acyloxazolidinone $(269 \mathrm{mg}$, $0.87 \mathrm{mmol})$ in THF $(3 \mathrm{~mL}$ ) was added to the solution by cannula, and the mixture was stirred for $30 \mathrm{~min}$. A precooled $\left(-78^{\circ} \mathrm{C}\right)$ solution of triisopropylbenzenesulfonyl azide $(38,330-340 \mathrm{mg}, 1.07-1.10 \mathrm{mmol})$ in THF $(3 \mathrm{~mL})$ was added by cannula to the solution of the resulting potassium enolate. After $1 \mathrm{~min}$, the reaction was quenched with glacial acetic acid $(0.23 \mathrm{~mL}, 4.0 \mathrm{mmol})$, the cooling bath was removed, and the mixture was immediately warmed to $25-30^{\circ} \mathrm{C}$ for $30 \mathrm{~min}$ with a water bath. The solution was partitioned between $\mathrm{CH}_{2} \mathrm{Cl}_{2}$ and brine $(40 \mathrm{~mL})$, the aqueous phase was washed three times with $\mathrm{CH}_{2} \mathrm{Cl}_{2}$, and the combined extracts were washed with saturated aqueous $\mathrm{NaHCO}_{3}$, dried over anhydrous $\mathrm{MgSO}_{4}$, and evaporated under vacuum. The resulting crude materials were purified by mediumpressure column chromatography $(50 \mathrm{~g}$ of silica gel, $1 \mathrm{~L}$ linear gradient from $\mathrm{CH}_{2} \mathrm{Cl}_{2} /$ hexane 6:4 to $\mathrm{CH}_{2} \mathrm{Cl}_{2}$ ) to give [3(2S),4S]-3-(2-azido-3-phenyl-1-oxopropyl)4-(phenylmethyl)-2-oxazolidinone ( $278 \mathrm{mg}, 0.79 \mathrm{mmol}$ ) in $91 \%$ yield.

1) $\mathrm{KN}\left[\mathrm{Si}\left(\mathrm{NMe}_{2}\right)_{3}\right]$<smiles>O=C(CCc1ccccc1)N1C(=O)OC[C@@H]1Cc1ccccc1</smiles>

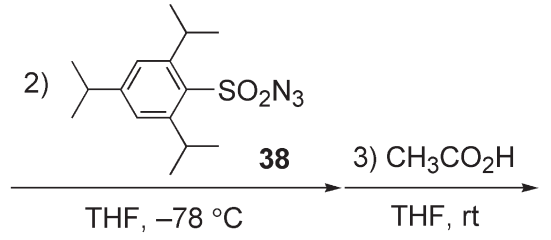<smiles>N[C@@H](Cc1ccccc1)C(=O)N1C(=O)OC[C@H]1CPc1ccccc1</smiles>

Representative procedure for azidation of alkyl radicals with phenylsulfonyl azide Ditert-butylhyponitrite $(10 \mathrm{mg}, 0.06 \mathrm{mmol})$ was added to a solution of the iodide (365 mg, $1.0 \mathrm{mmol})$, phenylsulfonyl azide $(39,550 \mathrm{mg}, 3.0 \mathrm{mmol})$, and $\left(\mathrm{Bu}_{3} \mathrm{Sn}\right)_{2}$ $(0.76 \mathrm{~mL}, 1.5 \mathrm{mmol})$ in benzene $(2 \mathrm{ml})$ at reflux under $\mathrm{N}_{2}$. The reaction was monitored by TLC. Upon completion, the solvent was removed under reduced pressure, and the resulting crude materials were filtered through silica gel (hexane, then hexane/AcOEt $85: 15)$. After the combined fractions had been concentrated under vacuum, the residue was purified by flash column chromatography (silica gel. hexane/AcOEt $85: 15)$ to give 4-azido-1-[(4-methylphenyl)sulfonyl]piperidine ( $249 \mathrm{mg}, 0.89 \mathrm{mmol}$ ) in $89 \%$ yield.

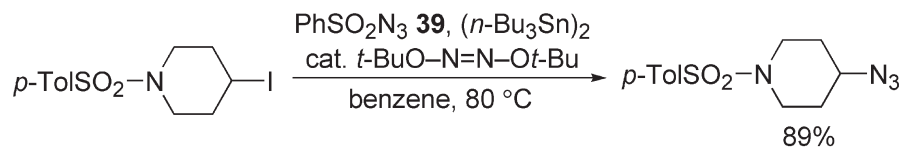

Representative procedure for hydroazidation of alkenes with sulfonyl azides $\mathrm{Co}\left(\mathrm{BF}_{4}\right)_{2} \cdot 6 \mathrm{H}_{2} \mathrm{O}(10 \mathrm{mg}, 0.030 \mathrm{mmol})$ and the ligand $(14 \mathrm{mg}, 0.030 \mathrm{mmol})$ 
were dissolved in ethanol $(2.5 \mathrm{~mL})$ at $23^{\circ} \mathrm{C}$ under argon. After $10 \mathrm{~min}$, 4-phenylbut1-ene $(75 \mu \mathrm{L}, 0.50 \mathrm{mmol})$, followed by $p$-tolylsulfonyl azide $(40,0.23 \mathrm{~mL}, 1.5 \mathrm{mmol})$ and tert-butyl hydroperoxide $(5.5 \mathrm{M}$ in decane, $25 \mu \mathrm{L}, 0.14 \mathrm{mmol}$ ), were added to the solution. After $5 \mathrm{~min}$, phenylsilane $(0.10 \mathrm{~mL}, 0.80 \mathrm{mmol})$ was added dropwise. The resulting brown solution was stirred at $23^{\circ} \mathrm{C}$. After completion, the reaction was quenched with $\mathrm{H}_{2} \mathrm{O}(2 \mathrm{~mL})$, and saturated aqueous $\mathrm{NaHCO}_{3}(2 \mathrm{~mL})$ and brine $(5 \mathrm{~mL})$ were added to the mixture. The organic materials were extracted with EtOAc $(3 \times 10 \mathrm{~mL})$, and the combined extracts were dried over anhydrous $\mathrm{Na}_{2} \mathrm{SO}_{4}$. The solvents were removed under reduced pressure, and the resulting crude materials were purified by flash column chromatography to give (3-azidobutyl)benzene (79 mg, $0.45 \mathrm{mmol}$ ) in $90 \%$ yield.

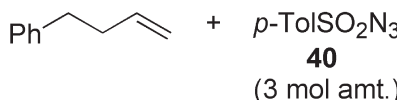

$6 \mathrm{~mol} \% \mathrm{Co}\left(\mathrm{BF}_{4}\right)_{2} \cdot 6 \mathrm{H}_{2} \mathrm{O}$

$6 \mathrm{~mol} \%$ ligand

$30 \mathrm{~mol} \% \mathrm{t}-\mathrm{BuOOH}$

$1.6 \mathrm{~mol}$ amt. $\mathrm{PhSiH}_{3} \longrightarrow$

$\mathrm{EtOH}, 23^{\circ} \mathrm{C}, 2 \mathrm{~h}$
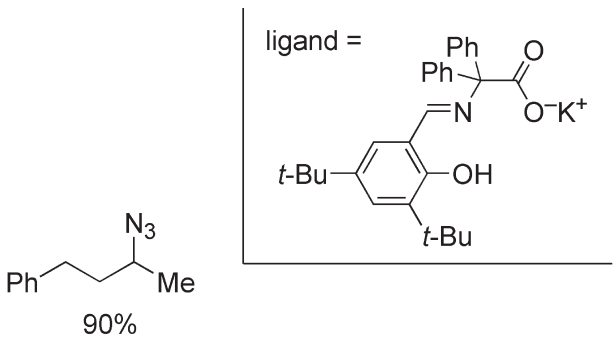

1.10

Gabriel-Type Reagents

1.10 .1

\section{Nucleophilic Amination Reactions}

The Gabriel synthesis is a classical, but still very useful nucleophilic amination method for the synthesis of simple primary amines [88]. The first step of the Gabriel method, the formation of $N$-alkylphthalimide, includes substitution reactions of potassium phthalimide with alkyl halides and alkyl sulfonates. The second procedure, the conversion of the $\mathrm{N}$-alkylphthalimides into primary amines, requires strongly acidic or basic conditions, or can alternatively be carried out by treatment with hydrazine. These severe reaction conditions prevent the application to polyfunctionalized compounds containing carbonyl groups and halogen equivalents.

To solve these problems, a number of alternatives to phthalimide have been developed in order to allow the second deprotection step to be carried out under milder conditions. Some of these reagents were reviewed by Ragnarsson in 1991 and are shown in Figure 1.2 [89], whereas other Gabriel-type reagents developed recently are covered in the following examples.

Bis(2-trimethylsilylethanesulfonyl)imide $\left(\mathrm{SES}_{2} \mathrm{NH}, 48\right)$, easily prepared by alkylation of bis(methanesulfonyl)imide by treatment with LHMDS and (iodomethyl)t rimethylsilane, is used in the synthesis of protected primary amines (Scheme 
<smiles>[R]OC(=O)NC([R2])=O</smiles>

41<smiles>O=CCNC=O</smiles>

43<smiles></smiles><smiles>CCOC(=O)NP(=O)(OCC)OCC</smiles>

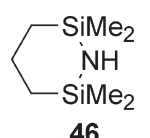

46<smiles>O=C1NS(=O)(=O)c2ccccc21</smiles><smiles>O=C(NC(=O)c1ccccc1)OCc1ccccc1</smiles>

Figure 1.2 Gabriel-type reagents.<smiles>CC(C)=CCCC(C)=CCO</smiles><smiles>CCON(OCC)c1ccccc1</smiles>

48

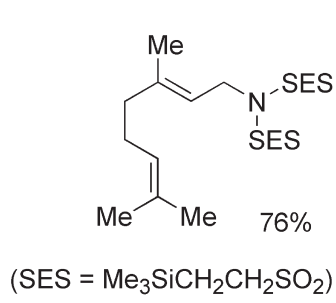<smiles>CC(CC(C)(F)F)C(C)C(C)(F)F</smiles><smiles>CC(C)=CCCC(C)=CCN[Si]#[SH]</smiles>

Scheme 1.72 Synthesis of protected primary amines by Mitsunobu alkylation of $\mathbf{4 8 .}$

1.72). This reagent undergoes Mitsunobu alkylation with both primary and secondary alcohols to afford the corresponding bis-SES imides. These imides can be selectively cleaved to the mono-SES-protected amines by treatment with CsF. In addition, one-pot monodeprotection/ $\mathrm{N}$-alkylation can be carried out by successive treatment with $\mathrm{CsF}$ and an alkylating agent such as benzyl bromide, affording $N$ alkyl mono-SES amino derivatives [90].

1,2,4-Dithiazolidine-3,5-dione (49) [91] is used for nucleophilic $N$-alkylation with alkyl halides and for Mitsunobu reactions with alcohols (Scheme 1.73) [92]. The resulting $N$-alkyl-1,2,4-dithiazolidine-3,5-diones are readily converted into urethanes via isocyanates by treatment with triphenylphosphine and alcohol. 

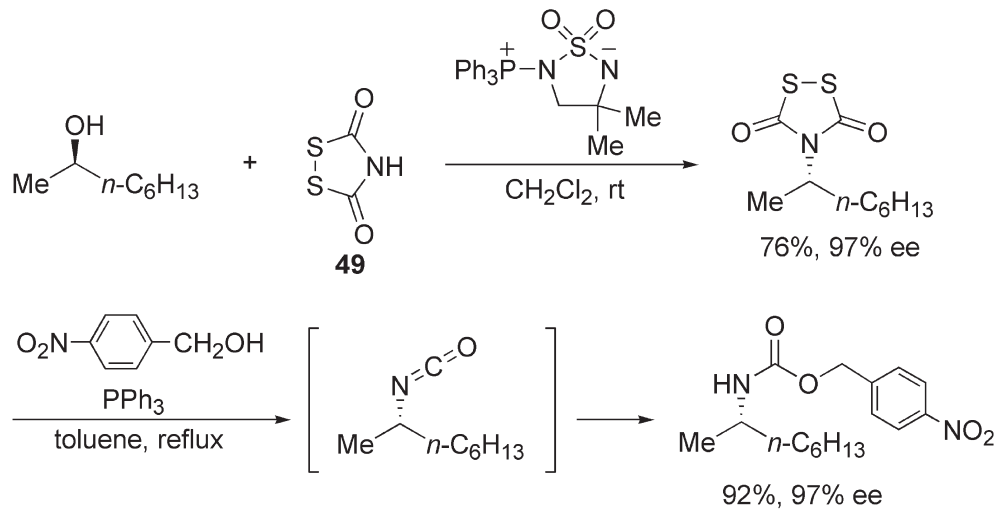

Scheme 1.73 Nucleophilic $N$-alkylation of $\mathbf{4 9}$ with alkyl halides.<smiles>CC(=O)OC(/C=C/c1ccccc1)c1ccccc1</smiles>

Scheme 1.74<smiles>COC(=O)OC/C=C/c1ccccc1</smiles>

Scheme 1.75<smiles>CC(C)(C)OC(=O)NCC1CCCCC1</smiles>

50<smiles>C=C[C@H](c1ccccc1)N(C=O)C(=O)C(C)(C)C</smiles>

$98 \%, 98.5 \%$ ee

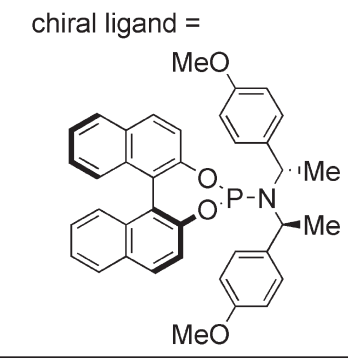

Some Gabriel-type reagents have been applied to transition metal-catalyzed allylic amination. Ding, for example, reported the asymmetric synthesis of allylic amines from allylic acetates with sodium $N, N$-diformamide (43), catalyzed by allylpalladium chloride dimer and BINAP (Scheme 1.74) [93].

Iridium complexes are also suitable catalysts for the synthesis of chiral allylic amines [94]. When a mixture of allylic carbonate and tert-butyl formylcarbamate (50) is treated with a catalytic amount of $\left[\operatorname{Ir}(\operatorname{cod}) \mathrm{Cl}_{2}\right.$ and a chiral amino phosphine ligand, the corresponding allylic amine derivative is obtained with good regioselectivity favoring the branched product, as well as with high enantioselectivity (Scheme 1.75). 
1.10 .2

\section{Experimental Procedure}

Representative nucleophilic amination with 1,2,4-dithiazolidine-3,5-dione $\quad(R)$-Octan2 -ol $(120 \mu \mathrm{L}, 0.76 \mathrm{mmol})$ was added at room temperature to a solution of $1,2,4-$ dithiazolidine-3,5-dione $(49,110 \mathrm{mg}, 0.82 \mathrm{mmol})$ and the betaine condensation reagent $\left(345 \mathrm{mg}, 0.84 \mathrm{mmol}\right.$ ) in $\mathrm{CH}_{2} \mathrm{Cl}_{2}(2 \mathrm{~mL})$. After the mixture had been stirred for $18 \mathrm{~h}$, the solvent was evaporated under vacuum, and the resulting residue was purified by flash column chromatography (silica gel, petroleum ether/EtOAc 9:1) to give (S)-4-(1-methylheptyl)-1,2,4-dithiazolidine-3,5-dione (142 mg, $0.58 \mathrm{mmol}$ ) in $76 \%$ yield.

4-Nitrobenzyl alcohol $(60 \mathrm{mg}, 0.39 \mathrm{mml})$ was added to a solution of $(S)$-4(1-methylheptyl)-1,2,4-dithiazolidine-3,5-dione $(120 \mathrm{mg}, 0.49 \mathrm{mmol})$ and triphenylphosphine $(130 \mathrm{mg}, 0.50 \mathrm{mmol})$ in toluene $(2 \mathrm{~mL})$, and the reaction mixture was stirred at reflux for $48 \mathrm{~h}$. The solvent was removed under reduced pressure, and the resulting residue was purified by flash column chromatography (silica gel, petroleum ether/EtOAc 9:1) to give (S)-(4-nitrobenzyl)-1-methylheptyl carbamate (111 mg, $0.36 \mathrm{mmol}$ ) in $92 \%$ yield based on 4-nitrobenzyl alcohol and with $97 \%$ ee (determined by chiral HPLC).

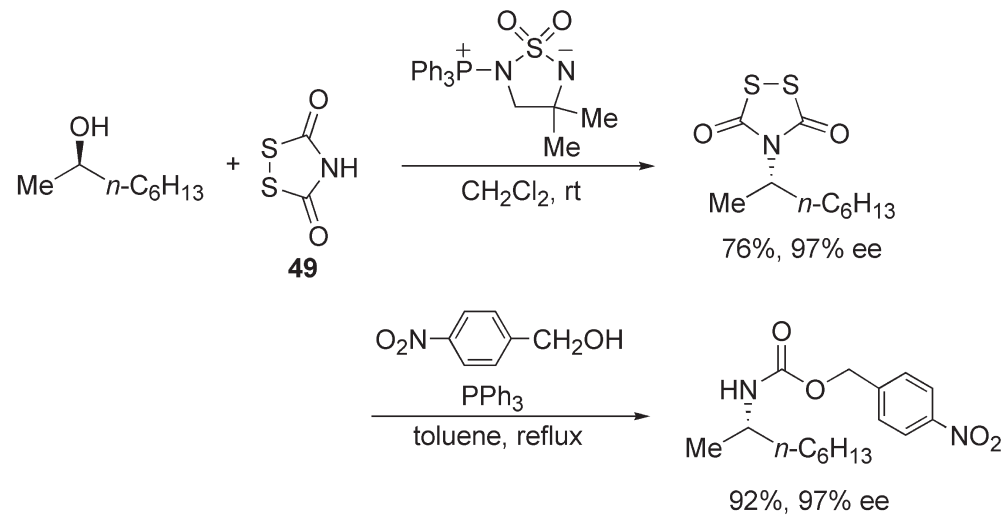

Representative palladium-catalyzed allylic amination with sodium $\mathrm{N}, \mathrm{N}$-diformylamide 1,3-Diphenylprop-2-en-1-yl acetate $(46.8 \mathrm{mg}, 0.186 \mathrm{mmol})$ and $\mathrm{Et}_{3} \mathrm{~N}(26 \mu \mathrm{L}$, $0.186 \mathrm{mmol})$ were added to a solution of allylpalladium chloride dimer $(1.7 \mathrm{mg}$, $0.0047 \mathrm{mmol})$ and $(S)$-BINAP $(6.7 \mathrm{mg}, 0.0112 \mathrm{mmol})$ in 1,2-dichloroethane $(3 \mathrm{~mL})$, and the mixture was stirred for $10 \mathrm{~min}$. After the mixture had been cooled to $0{ }^{\circ} \mathrm{C}$, sodium $N, N$-diformamide $(43,106 \mathrm{mg}, 1.116 \mathrm{mmol})$ was added. The reaction mixture was stirred at $0^{\circ} \mathrm{C}$ for $6 \mathrm{~h}$. After filtration, the solvent was evaporated under vacuum, and the resulting residue was purified by flash column chromatography (silica gel, hexane/EtOAc 4:1) to give (S)-N,N-diformyl-1,3-diphenyl-2-propenoylamide $(49.0 \mathrm{mg})$ in $99 \%$ yield and with $99 \% \mathrm{ee}$. 


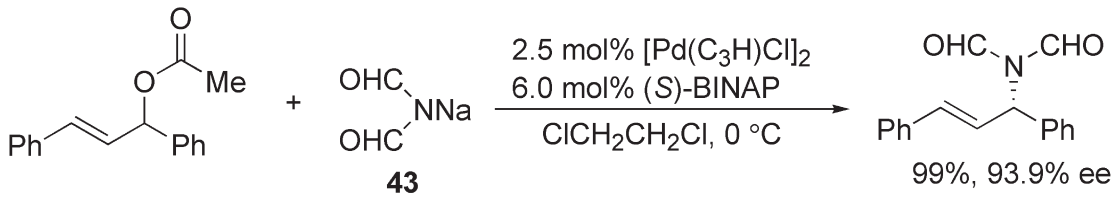

\subsection{1}

\section{Conclusion}

This chapter reviews the recent advances in the field of simple amination reagents, which have allowed synthetically efficient introduction of various nitrogen units into organic molecules, with the formation of new carbon-nitrogen bonds. Other widely used nitrogen-containing small molecules such as nitroso compounds [95], nitrites [96], or nitrogen monoxide [97] are outside the scope of this chapter and are discussed elsewhere. Nitrogen atom transfer to organic molecules through cleavage of dinitrogen by the action of transition metal complexes has also recently been reported [98] and the further development of metal-catalyzed amination reactions with dinitrogen will certainly become a challenging research area in the future.

\section{References and Notes}

1 Y. Tamura, J. Minamikawa, M. Ikeda, Synthesis 1977, 1-17.

2 N. L. Sheverdina, Z. Kocheskov, J. Gen. Chem. USSR 1938, 8, 1825-1829.

3 G. Boche, H. H. Wagner, J. Chem. Soc., Chem. Commun. 1984, 1591-1592.

4 a) J. P. Genêt, S. Mallart, C. Greck, E. Piveteau, Tetrahedron Lett. 1991, 32, 2359-2362. b) C. Greck, L. Bischoff, A. Girard, J. Hajicek, J. P. Genêt, Bull. Soc. Chim. Fr. 1994, 131, 429-433.

5 C. Greck, L. Bischoff, F. Ferreira, J. P. Genêt, J. Org. Chem. 1995, 60, 7010-7012.

6 G. Boche, C. Boie, F. Bosold, K. Harms, M. Marsch, Angew. Chem. Int. Ed. 1994, 33, 115-117.

7 N. Zheng, J. D. Armstrong, III, J. C. McWilliams, R. P. Volante, Tetrahedron Lett. 1997, 38, 2817-2820.

8 J. P. Genêt, J. Hajicek, L. Bischoff, C. Greck, Tetrahedron Lett. 1992, 33, 2677-2680.

9 a) S. Fioravanti, M. Antonietta, L. Pellacani, P. A. Tardella, Tetrahedron Lett. 1993, 34, 4353-4354. b) M. Barani, S.
Fioravanti, L. Pellacani, P. A. Tardella, Tetrahedron 1994, 50, 11235-11238.

10 a) S. Fioravanti, L. Pellacani, S. Stabile, P. A. Tardella, Tetrahedron Lett. 1997, 38 3309-3310. b) S. Fioravanti, L. Pellacani, S. Stabile, P. A. Tardella, Tetrahedron 1998, 54, 6169-6176. c) S. Fioravanti, A. Morreale, L. Pellacani, P. A. Tardella, Synthesis 2001, 1975-1978. d) S. Fioravanti, A. Morreale, L. Pellacani, P. A. Tardella, J. Org. Chem. 2002, 67, 4972-4974. e) S. Fioravanti, A. Morreale, L. Pellacani, P. A. Tardella, Eur. J. Org. Chem. 2003, 45494552. f) S. Fioravanti, M. Gabriella Mascia, A. Morreale, L. Pellacani, P. A. Tardella, Eur. J. Org. Chem. 2002, 4071-4074.

11 a) G. Boche, Encyclopedia of Reagents for Organic Synthesis; L. A. Paquette, Ed.; J. Wiley \& Sons: New York, 1995; Vol. 4, p 2240-2242. b) G. Boche, M. Bernheim, W. Schrott, Tetrahedron Lett. 1982, 23, 5399-5402.

12 J. A. Smulik, E. Vedejs, Org. Lett. 2003, 5, 4187-4190.

13 G. Boche, Encyclopedia of Reagents for Organic Synthesis, L. A. Paquette, Ed., 
J. Wiley \& Sons, New York, 1995, Vol. 5, pp. 3270-3271.

14 a) A. M. Berman, J. S. Johnson, J. Am. Chem. Soc. 2004, 126, 5680-5681. b) A. M. Berman, J. S. Johnson, J. Org. Chem. 2005, 70, 364-366. c) A. M. Berman, J. S. Johnson, J. Org. Chem. 2006, 71, 219224. d) A. M. Berman, J. S. Johnson, Org. Syn. 2006, 83, 31-37.

15 A. Casarini, P. Dembech, D. Lazzari, E. Marini, G. Reginato, A. Ricci, G. Seconi, J. Org. Chem. 1993, 58, 5620-5623.

16 P. Bernardi, P. Dembech, G. Fabbri, A. Ricci, G. Seconi, J. Org. Chem. 1999, 64, 641-643.

17 For recent reviews on the synthetic applications of oxime derivatives, see: a) J. P. Adams, J. Chem. Soc., Perkin Trans 1, 2000, 125-139. b) E. Abele, E. Lukevics, Heterocycles 2000, 53, 2285-2336. c) K. Narasaka, M. Kitamura, Eur. J. Org. Chem. 2005, 4505-4519. d) M. Yamane, K. Narasaka, Science of Synthesis, Vol. 27: Carbons with Two Carbon-Heteroatom Bonds: Heteroatom Analogues of Aldehydes and Ketones, A. Padwa, Ed., Thieme, Stuttgart, 2004, Chapter 15.

18 R. A. Hagopian, M. J. Therien, J. R. Murdoch, J. Am. Chem. Soc. 1984, 106, 5753-5754.

19 a) E. Erdik, M. Ay, Synth. React. Inorg. Met.-Org. Chem. 1989, 19, 663-668. b) E. Erdik, T. Daskapan, Synth. Commun. 1999, 29, 3989-3997. c) E. Erdik, T. Daskapan, J. Chem. Soc., Perkin Trans. I 1999, 3139-3142. d) E. Erdik,

Encyclopedia of Reagents for Organic Synthesis, L. A. Paquette, Ed., J. Wiley \& Sons, New York, 1995; Vol. 1, p 41-42.

20 E. Erdik, T. Daskapan, Tetrahedron Lett. 2002, 43, 6237-6239.

21 H. Tsutsui, T. Ichikawa, K. Narasaka, Bull. Chem. Soc. Jpn. 1999, 72, 1869-1878.

22 R. W. Hoffmann, B. Hölzer, O. Konpff, Org. Lett. 2001, 3, 1945-1948.

23 M. Kitamura, S. Chiba, K. Narasaka, Bull. Chem. Soc. Jpn. 2003, 76, 1063-1070.

24 N. Baldovini, M. Kitamura, K. Narasaka, Chem. Lett. 2003, 32, 548-549.

25 M. Kitamura, T. Suga, S. Chiba, K. Narasaka, Org. Lett. 2004, 6, 4691-4693.
26 L. Boymond, M. Rottlander, G. Cahiez, P. Knochel, Angew. Chem. Int. Ed. 1998, 37, 1701-1703.

27 W. Dohle, D. M. Lindsay, P. Knochel, Org. Lett. 2001, 3, 2871-2873.

28 S. Chiba, K. Narasaka, unpublished results.

29 a) J. P. Genêt, C. Greck, D. Lavergne, Modern Amination Methods, A. Ricci, Ed., Wiley-VCH, Weinheim, 2000, Chapter 3. b) E. Erdik, Tetrahedron 2004, 60, 8747-8782.

30 W. A. Thaler, B. Franzus, J. Org. Chem. 1964, 29, 2226-2235.

31 Y. Leblanc, R. Zamboni, M. A. Bernstein, J. Org. Chem. 1991, 56, 1971-1972.

32 M. A. Brimble, C. H. Heathcock, J. Org. Chem. 1993, 58, 5261-5263.

33 a) A. G. Davies, W. J. Kinart, J. Chem. Soc. Perkin Trans. II 1993, 2281-2284. b) W. J. Kinart, J. Chem. Res., Synop. 1994, 486-487.

34 a) J. Waser, E. M. Carreira, J. Am. Chem. Soc. 2004, 126, 5676-5677. b) J. Waser, E. M. Carreira, Angew. Chem. Int. Ed. 2004, 43, 4099-4102. c) J. Waser, J. C. GonzálezGómez, H. Nambu, P. Huber, E. M. Carreira, Org. Lett. 2005, 7, 4249-4252. d) J. Waser, B. Gaspar, H. Nambu, E. M. Carreira, J. Am. Chem. Soc. 2006, 128, 11693-11712.

35 S. M. Weinreb, Comprehensive Organic Synthesis, B. M. Trost, I. Fleming, L. A. Paquette, Eds., Pergamon: Oxford, 1991, Vol. 5, 401-449.

36 M. F. Ahern, A. Leopold, J. R. Beadle, G. W. Gokel, J. Am. Chem. Soc. 1982, 104, 548-554.

37 C. Dell'Erba, M. Novi, G. Petrillo, C. Tavani, Tetrahedron 1995, 51, 3905-3914.

38 C. Dell'Erba, M. Novi, G. Petrillo, C. Tavani, Tetrahedron 1997, 53, 2125-2136.

39 I. Sapountzis, P. Knochel, Angew. Chem. Int. Ed. 2004, 43, 897-900.

40 For a review, see: F. A. Davis, A. C. Sheppard, Tetrahedron 1989, 45, 5703-5742.

41 J. Vidal, S. Damestoy, L. Guy, J. C. Hannachi, A. Aubry, A. Collet, Chem. Eur. J. 1997, 3, 1691-1709.

42 J. Vidal, L. Guy, S. Stérin, A. Collet, J. Org. Chem. 1993, 58, 4791-4793. 
43 a) A. Armstrong, M. A. Atkin, S. Swallow, Tetrahedron Lett. 2000, 41, 2247-2251. b) A. Armstrong, I. D. Edmonds, M. E. Swarbrick, N. R. Treweeke, Tetrahedron 2005, 61, 8423-8442.

44 A. Armstrong, R. S. Cooke, Chem. Commun. 2002, 904-905.

45 A. Armstrong, L. Challinor, R. S. Cooke, J. H. Moir, N. R. Treweeke, J. Org. Chem. 2006, 71, 4028-4030.

46 A. Armstrong, R. S. Cooke, S. F. Shanahan, Org. Biomol. Chem. 2003, 1, 3142-3143.

47 R. R. Goehring, Encyclopedia of Reagents for Organic Synthesis, L. A. Paquette, Ed. J. Wiley \& Sons, New York, 1995, Vol. 2, p 1054-1056.

48 D. H. R. Barton, M. R. Britten-Kelly, D. Ferreira, J. Chem. Soc., Perkin Trans. 1 1978, 1090-1100.

49 a) K. B. Sharpless, A. O. Chong, K. Oshima, J. Org. Chem. 1976, 41, 177-179. b) E. Herranz, K. B. Sharpless, J. Org. Chem. 1978, 43, 2544-2548.

50 K. B. Sharpless, D. W. Patrick, L. K. Truesdale, S. A. Biller, J. Am. Chem. Soc. 1975, 97, 2305-2307.

51 a) G. Li, H. T. Chang, K. B. Sharpless, Angew. Chem. Int. Ed. 1996, 35, 451-454. b) A. E. Rubin, K. B. Sharpless, Angew. Chem. Int. Ed. 1997, 36, 2637-2640.

52 G. Li, H. H. Angert, K. B. Sharpless, Angew. Chem. Int. Ed. 1996, 35, 2813-2817. The original report on carbamate-based osmium-catalyzed aminohydroxylation of alkenes appeared in 1978, see: E. Herranz, S. A. Biller, K. B. Sharpless, J. Am. Chem. Soc. 1978, 100, 3596-3598.

53 a) B. Cao, H. Park, M. M. Joullie, J. Am. Chem. Soc. 2002, 124, 520-521. b) W. Jiang, J. Wanner, R. J. Lee, P. Y. Bounaud, D. L. Boger, J. Am. Chem. Soc. 2003, 125, 1877-1887. c) B. M. Crowley, Y. Mori, C. C. McComas, D. Tang, D. L. Boger, J. Am. Chem. Soc. 2004, 126, 4310-4317. d) W. Kurosawa, H. Kobayashi, T. Kan, T. Fukuyama, Tetrahedron 2004, 60, 9615-9628.

54 T. Ando, S. Minakata, I. Ryu, M. Komatsu, Tetrahedron Lett. 1998, 39, 309-312.
55 D. P. Albone, P. S. Aujla, P. C. Taylor, S. Challenger, A. M. Derrick, J. Org. Chem. 1998, 63, 9569-9571.

56 L. Simkhovich, Z. Gross, Tetrahedron Lett. 2001, 42, 8089-8092.

57 S. Minakata, D. Kano, R. Fukuoka, Y. Oderaotoshi, M. Komatsu, Heterocycles 2003, 60, 289-298.

58 J. U. Jeong, B. Tao, I. Sagasser, H. Henniges, K. B. Sharpless, J. Am. Chem. Soc. 1998, 120, 6844-6845.

59 S. L. Ali, M. D. Nikalje, S. Sudalai, Org. Lett. 1999, 1, 705-707.

60 T. Ando, D. Kano, S. Minakata, I. Ryu, M. Komatsu, Tetrahedron 1998, 54, 13485-13494.

61 D. Kano, S. Minakata, M. Komatsu, J. Chem. Soc., Perkin Trans. 12001 , 3186-3188.

62 S. Minakata, D. Kano, Y. Oderaotoshi, M. Komatsu, Angew. Chem. Int. Ed. 2004, 43, 79-91.

63 S. Minakata, D. Kano, Y. Oderaotoshi, M. Komatsu, Org. Lett. 2002, 4, 20972099.

64 S. Minakata, Y. Yoneda, Y. Oderaotoshi, M. Komatsu, Org. Lett. 2006, 8, 967-969.

65 Synthesis of $N$ sulfonyliminophenyliodinane, see: a) Y. Yamada, T. Yamamoto, M. Okawara, Chem. Lett. 1975, 361-362. b) M. J. Sodergren, D. A. Alonso, A. V. Bedekar, P. G. Andersson, Tetrahedron Lett. 1997, 38, 6897-6900.

66 a) D. Mansuy, J.-P. Mahy, A. Duresult, G. Bedi, P. Battioni, J. Chem. Soc., Chem. Commun. 1984, 1164-1163. b) J.-P. Mahy, G. Bedi, P. Battioni, D. Mansuy, Tetrahedron Lett. 1988, 29, 1927-1930. c) J.-P. Mahy, G. Bedi, P. Battioni, D. Mansuy, J. Chem. Soc., Perkin Trans. II 1988, 1517-1524.

67 S.-M. Au, W.-H. Fung, M.-C. Cheng, C.-M. Che, S.-M. Peng, Chem. Commun. 1997, 1655-1656.

68 a) P. Müller, C. Baud, Y. Jacquier, Tetrahedron 1996, 52, 1543-1548. b) P. Müller, C. Baud, Y. Jacquier, Can. J. Chem. 1998, 76, 738-750.

69 a) D. A. Evans, M. M. Faul, M. T. Bilodeau, J. Org. Chem. 1991, 56, 67446746. b) D. A. Evans, M. M. Faul, M. T. Bilodeau, J. Am. Chem. Soc. 1994, 116, 
2472-2753. c) P. Dauban, R. H. Dodd, J. Org. Chem. 1999, 63, 5304-5307.

70 Y. Cui, C. He, J. Am. Chem. Soc. 2003, 125, 16202-16203.

71 For a review, see: P. Müller, C. Fruit, Chem. Rev. 2003, 103, 2905-2919.

72 K. Guthikonda, J. Du Bois, J. Am. Chem. Soc. 2002, 124, 13672-13673.

73 Z. Li, X. Ding, C. He, J. Org. Chem. 2006, 71, 5876-5880.

74 a) W. P. Griffith, Coord. Chem. Rev. 1972, 8, 369-396. b) K. Dehnicke, J. Strähle, Angew. Chem. Int. Ed. 1992, 31, 955-978. c) R. A. Eikey, M. M. Abu-Omar, Coord. Chem. Rev. 2003, 243, 83-124.

75 a) J. Du Bois, J. Hong, E. M. Carreira, M. W. Day, J. Am. Chem. Soc. 1996, 118, 915-916. b) J. Du Bois, C. S. Tomooka, J. Hong, E. M. Carreira, J. Am. Chem. Soc. 1997, 119, 3179-3180. c) J. Du Bois, C. S. Tomooka, J. Hong, E. M. Carreira, Acc. Chem. Res. 1997, 30, 364-372. d) J. Du Bois, C. S. Tomooka, J. Hong, E. M. Carreira, M. W. Day, Angew. Chem. Int. Ed. 1997, 36, 1645-1647. e) E. M. Carreira, J. Hong, J. Du Bois, C. S. Tomooka, Pure Q Appl. Chem. 1998, 70, 1097-1103.

76 S. K.-Y. Leung, J.-S. Huang, J.-L. Kiang, C.-M. Che, Z.-Y. Zhou, Angew. Chem. Int. Ed. 2003, 42, 340-343.

77 a) S. Minakata, T. Ando, M. Nishimura, I. Ryu, M. Komatsu, Angew. Chem. Int. Ed. 1998, 37, 3392-3394. b) M.

Nishimura, S. Minakata, S. Thongchant, I. Ryu, M. Komatsu, Tetrahedron Lett. 2000, 41, 7089-7092. c) M. Nishimura, S. Minakata, T. Takahashi, Y. Oderaotoshi, M. Komatsu, J. Org. Chem. 2002, 67, 2101-2110.

78 a) R. Huisgen, Angew. Chem. Int. Ed. 1963, 2, 565-598. b) R. Huisgen, R. Knorr, L. Möbius, G. Szeimies, Chem. Ber. 1965, 98, 4014-4021.

79 a) E. F. V. Scriven, K. Turnbull, Chem. Rev. 1988, 88, 297-368. b) S. Brase, C. Gil, K. Knepper, V. Zimmermann, Angew. Chem. Int. Ed. 2005, 44, 5188-5240.

80 a) B. M. Trost, W. H. Pearson, J. Am. Chem. Soc. 1981, 103, 2483-2485. b) B. M. Trost, W. H. Pearson, J. Am. Chem. Soc. 1983, 105, 1054-1056.
81 G. W. Kabalka, G. Li, Tetrahedron Lett. 1997, 38, 5777-5778.

82 K. Nishiyama, N. Tanaka, J. Chem. Soc., Chem. Commun. 1983, 1322-1323.

83 A. V. Thomas, Encyclopedia of Reagents for Organic Synthesis, L. A. Paquette, Ed., J. Wiley \& Sons: New York, 1995; Vol. 4, pp. 2242-2245, and references therein.

84 D. A. Evans, T. C. Britton, J. A. Ellman, R. L. Dorow, J. Am. Chem. Soc. 1990, 112, 4011-4030.

85 P. Panchaud, L. Chabaud, Y. Landais, C. Ollivier, P. Renaud, S. Zigmantas, Chem. Eur. J. 2004, 10, 3606-3614.

86 C. Ollivier, P. Renaud, J. Am. Chem. Soc. 2001, 123, 4717-4727.

87 a) P. Renaud, C. Ollivier, P. Panchaud, Angew. Chem. Int. Ed. 2002, 41, 3460-3462. b) P. Panchaud, C. Ollivier, P. Renaud, S. Zigmantas, J. Org. Chem. 2004, 69, 2755-2759.

88 a) S. Gabriel, Ber. Dtsch. Chem. Ges. 1887, 20, 2224-2236. b) M. S. Gibson, R. W. Bradshaw, Angew. Chem. Int. Ed. 1968, 7, 919-930. c) H. de Koning, W. Nico Speckamp, Encyclopedia of Reagents for Organic Synthesis, L. A. Paquette, Ed., J.Wiley \& Sons, New York, 1995, Vol. 6, pp. 4141-4143.

89 For a review, see: U. Ragnarsson, L. Grehn, Acc. Chem. Res. 1991, 24, 285289.

90 D. M. Dastrup, M. P. VanBrunt, S. M. Weinreb, J. Org. Chem. 2003, 68, 4112-4115.

91 G. Zumach, E. Kühle, Angew. Chem. Int. Ed. 1970, 9, 54-63.

92 a) D. J. Cane-Honeysett, M. D. Dowle, M. E. Wood, Synlett 2000, 1622-1624. b) M. E. Wood, D. J. Cane-Honeysett, M. D. Dowle, J. Chem. Soc., Perkin Trans. 1 2002, 20462047. c) M. E. Wood, D. J. CaneHoneysett, M. D. Dowle, S. J. Coles, M. B. Hursthouse, Org. Biomol. Chem. 2003, 1, 3015-3023. d) D. J. Cane-Honeysett, M. D. Dowle, M. E. Wood, Tetrahedron 2005, 61, 2141-2148.

93 Y. Wang, K. Ding, J. Org. Chem. 2001, 66, 3238-3241.

94 R. Weihofen, O. Tverskoy, G. Helmchen, Angew. Chem. Int. Ed. 2006. 45, 5546-5549. 
95 For a recent review, see: H. Yamamoto, N. Momiyama, Chem. Commun. 2005, 3514-3525.

96 K. Kato, T. Mukaiyama, Chem. Lett. 1992, 98 J. J. Curley, E. L. Sceats, C. C. Cummins, $1137-1140$.

97 a) E. Hata, K. Kato, T. Yamada, T. Mukaiyama, J. Syn. Org. Jpn. 1996, 54,
728-739. b) E. Hata, T. Yamada, T. Mukaiyama, Bull. Chem. Soc. Jpn. 1995, 68, 3629-3636.

J. Am. Chem. Soc. 2006, 128, 14036-14037, and references therein. 